Pengantar:

Prof. Dr. H. Akhyak, M.Ag.

\title{
YANG TERDEPAN DALAM MENGHADAPI PEMBELANARAN DARING
}

Anita - Rif'iy Qomarullah - Muhammad Yusuf Arif Friyadi - Dita Lestari - Susana Labuem - Mahsunah -

Taufik Rahman - Andarini Permata CahyaningtyasSiti Khoirun Nisak - Oce Regina Talan -

Sholihatul Hamidah Daulay - Abdul Gafur Marzuki Benny Badaru - Wahyu Indra Bayu - Ulfah Mey Lida Rina Gustini-Siti Marlida - Muzayyidatul Habibah Nurlia Latipah - Nurika Khalila Daulay - Santiana -

Rohmah Ivantri - Rina Delfina - Siti Nurjannah Wellfarina Hamer - Kurratul Aini - Sri Okta Puspita Siti Zukana - Ndaru Kukuh Masgumelar

Editor:

Dr. Adi Wijayanto, S.Or., S.Kom., M.Pd., AIFO.

Prof. Dr. Jonni Siahaan., M.Kes., AIFO.

Dr. Adirasa Hadi Prasetyo, M.Pd.I

Martati, M.Pd. 


\section{Yang Terdepan dalam Menghadapi Pembelajaran Daring}

Copyright (C) Anita, dkk., 2021

Hak cipta dilindungi undang-undang

All right reserved

Editor: Adi Wijayanto, dkk.

Layouter: Muhamad Safi'i

Desain cover: Dicky M. Fauzi

Penyelaras akhir: Saiful Mustofa

$\mathrm{x}+235 \mathrm{hlm}: 14 \mathrm{x} 21 \mathrm{~cm}$

Cetakan: Pertama, Juni 2021

ISBN:

\section{Anggota IKAPI}

Hak cipta dilindungi undang-undang. Dilarang memplagiasi atau memperbanyak seluruh isi buku ini tanpa izin tertulis dari penerbit.

Diterbitkan oleh:

Akademia Pustaka

Perum. BMW Madani Kavling 16, Tulungagung

Telp: 081216178398

Email: redaksi.akademia.pustaka@gmail.com

Website: www.akademiapustaka.com 


\section{Kata Pengantar}

Duji syukur dipanjatkan kehadirat Allah SWT Tuhan Yang Maha Esa, berkat rahmat dan karuniaNYA buku Bunga Rampai dengan judul "YANG TERDEPAN DALAM MENGHADAPI PEMBELAJARAN DARING" selesai disusun. Buku ini merupakan karya anak bangsa, yang ditulis secara kolaboratif oleh para akademisi dari berbagai perguruan tinggi nasional dan para praktisi bidang pendidikan nasional. Gagasan penulisan kolaboratif ini muncul saat terjadi Pandemi Covid-19, topik-topik tulisan yang cukup menarik dari para penulis muncul sebagai upaya membantu pemikiran menghadapi situasi yang berubah secara drastis. Prediksi berbagai pihak bahwa belajar di rumah secara digital (online) diperkirakan relatif tidak dapat mewujudkan hasil belajar yang optimal, seperti diketahui bahwa hasil belajar di sekolah secara umum diukur melalui tiga domain yaitu kognitif, psikomotor dan afektif. Tiga Domain tersebut diyakini masih dapat diwujudkan melalui online meskipun relatif kurang optimal hasil belajarnya.

Upaya untuk mempertahankan kualitas pendidikan yang diukur dari tingkat capaian hasil belajar di tengah Pandemi Covid-19 tentu menjadi target dari para penulis Bunga Rampai ini yang dijabarkan dalam berbagai topik sebagaimana tututan kurikulum. Secara garis besar ukuran yang dapat digunakan dari tiga domain adalah meningkatnya pengetahuan murid melalui apa yang dipelajari. Hal ini tidak luput dari 
pemikiran penulis untuk membahasnya sehingga buku Bunga Rampai menjadi menarik bagi setiap pembaca.

Demikianlah beberapa hal yang dapat disampaikan sebagai penguatan dan penutup kata pengantar pada buku ini, semoga dengan hadirnya buku bunga rampai ini dapat menambah wawasan dan pengetahuan para pembaca secara khusus para guru, dosen dan pemerhati pendidikan serta kami berharap agar terus-menerus dapat menuliskan pemikiran empirisnya dalam buku bunga rampai lainnya.

Tulungagung, 5 Mei 2021

Prof. Dr. H. Akhyak, M.Ag. Direktur Pascasarjana UIN Sayyid Ali Rahmatullah Tulungagung 


\section{Daftar Isi}

Kata Pengantar ...............................................................................ii

Daftar Isi .............................................................................................

BAB I

PENDIDIK DAN PESERTA DIDIK DALAM

PEMBELAJARAN DARING

PEMBELAJARAN ONLINE: MEMBANGUN

KETERLIBATAN GURU DAN SISWA ….......................... 3

Dr. Anita, S.S., M.Pd. (UIN Sultan Maulana Hasanuddin

Banten)

GURU BERADA DI GARDA TERDEPAN

MEWUJUDKAN PROGRAM PENDIDIKAN MERDEKA

BELAJAR.

Dr. Rif'iy Qomarullah.,S.Pd.,M.Or \& Prof. Dr. Jonni

Siahaan.,M.Kes.,AIFO (Universitas Cenderawasih Papua)

PERAN GURU TERHADAP PESERTA DIDIK DI MASA PANDEMI COVID-19

Muhammad Yusuf, S.Pd.I..M.Pd (STAI DDI Kota

Makassar/Bosowa School Makassar)

PENDIDIKAN KARAKTER KEPADA ANAK DALAM

PERSPEKTIF AL QUR'AN DAN HADITS ........................ 27

Arif Friyadi, Lc, M.Ag (IAIN Kudus)

MENGAJARKAN BERPUASA DENGAN CINTA PADA ANAK USIA DINI DI BULAN RAMADHAN PADA MASA

NEW NORMAL 35

Dita Lestari, M.Psi. (IAIN Bengkulu) 
“GURU IDOLA" DI TENGAH PANDEMI COVID-19 DALAM KACAMATA SISWA DI DAERAH TERPENCIL43 Susana Labuem, M.Pd (Universitas Pattimura PSDKU ARU)

MELAWAN MOMOK GURU MATEMATIKA DI MASA PANDEMI: SEBUAH PENGALAMAN 51 Mahsunah, S.Pd (SMAN 2 Pati)

IMPLEMENTASI PERMAINAN TRADISIONAL DALAM MENINGKATKAN PHYSICAL LITERACY ANAK DI MASA PANDEMI 59

Taufik Rahman, M.Pd. (STKIP PGRI Sumenep)

MENDEKATKAN ANAK DENGAN SASTRA MELALUI AUDIOBOOK 65

Andarini Permata Cahyaningtyas, M.Pd. (Universitas Islam Sultan Agung)

MENGAJARKAN BERSABAR MENJAGA KESEHATAN PADA ANAK DI MASA PANDEMI . .75

Siti Khoirun Nisak, S.Pd.I., M.Pd. (UIN Sayyid Ali

Rahmatullah Tulungagung)

MOTIVASI BELAJAR PESERTA DIDIK KELAS IX SMP NEGERI 3 WEWEWA TIMUR MENJELANG PENILAIAN AKHIR TINGKAT SATUAN PENDIDIKAN (PATSP) MASA PANDEMI COVID - 19 811

Oce Regina Talan, S.Pd.,Gr (Universitas Nusa Cendana Kupang)

BAB II INTEGRASI KEILMUAN DALAM PEMBELAJARAN DARING

U-DICTIONARY: APLIKASI ALTERNATIF PADA PEMBELAJARAN BAHASA INGGRIS SAAT PANDEMI911 Dr. Sholihatul Hamidah Daulay, S.Ag., M.Hum (Universitas Islam Negeri Sumatera Utara) 
EFEKTIFITAS PEMBELAJARAN BAHASA SECARA DARING DI MASA PANDEMI COVID-19 PADA MAHASISWA DI KOTA PALU

Abdul Gafur Marzuki (IAIN Palu)

PEMBELAJARAN DARING DI MASA PANDEMI COVID19 MELALUI APLIKASI SYAM-OK DI KAMPUS FIK UNM 109

Dr. Benny Badaru, S.Pd,M.Pd (Universitas Negeri

Makassar)

MODEL PEMBELAJARAN HIGHER ORDER THINKING SKILLS DALAM PENDIDIKAN JASMANI 117

Wahyu Indra Bayu (Universitas Sriwijaya)

PEMANFAATAN MEDIA PADLET DALAM PEMBELAJARAN MENULIS TEKS EKSPLANASI PADA SISWA KELAS XI SMA. 125

Ulfah Mey Lida, M.Pd. (IAIN Kudus)

KOLABORASI PEMBELAJARAN DARING DAN LURING DALAM MENINGKATKAN HASIL BELAJAR MATEMATIKA DI ERA PANDEMI COVID-19 133

Rina Gustini, S.Pd (MAN 2 Cilacap)

IMPLEMENTASI TEORI CITRA DA'I DALAM MENGEMBANGKAN EKSISTENSI DAKWAH DI MASA

PANDEMI

Siti Marlida, M.Ag (Universitas Muhammadiyah

Bandung)

RELEVANSI DAN REAKTUALISASI PRAKTIKUM

AUDIT BERBASIS ONLINE

Muzayyidatul Habibah, M.E. (IAIN Kudus)

ANALISIS PEMANFAATAN MODUL PADA PEMBELAJARAN IPA SMP/MTS SEBAGAI ALTERNATIF MEDIA PEMBELAJARAN DI MASA PANDEMI 153

Nurlia Latipah, M.Pd.Si (IAIN Bengkulu) 
BAB III

TEKNOLOGI PENDUKUNG PEMBELAJARAN DARING

ADAPTASI VIRTUAL BLENDED APPLICATION UNTUK OPTIMALISASI EFEKTIFITAS KULIAH DARING DI MASA PANDEMI COVID 19

Dr. Nurika Khalila Daulay, M.A. (UIN Sumatera Utara)

LEARNING MANAGEMENT SYSTEM (LMS): APLIKASI PEMBELAJARAN VIRTUAL DI MASA PANDEMI COVID-19 171

Santiana, S.S., M.Pd. (Universitas Siliwangi)

PEMANFAATAN YOUTUBE UNTUK PENILAIAN KETERAMPILAN PADA MAHASISWA PGMI DI ERA PEMBELAJARAN PANDEMI 179

Rohmah Ivantri, M.Pd.I (UIN Sayyid Ali Rahmatullah Tulungagung)

PEMBELAJARAN DARING BERBASIS ZOOM CLOUD MEETING PADA MASA PANDEMIK COVID-19 ........ 185 Ns. Rina Delfina, S.Kep, M.Kep (Universitas Bengkulu)

IMPLEMENTASI PENGGUNAAN APLIKASI VIDEO CONVERENCE CISCO WEBEX DALAM PELAKSANAAN PRAKTEK KOMUNITAS II PADA MASA PANDEMIC COVID-19

Siti Nurjannah, SKM.,M.Kes (Akademi Keperawatan Sri Bunga Tanjung Dumai)

HI TECH HI TOUCH: SENI MENGAJAR DI ERA DIGITAL MENGGUNAKAN BAHASA KASIH SAYANG 20201 Wellfarina Hamer, M.Pd. (IAIN Metro)

PEMBELAJARAN BERBASIS BLENDED LEARNING PADA MASA PANDEMI COVID-19. 209

Kurratul Aini, M.Pd. (STKIP PGRI Sumenep)

PEMANFAATAN PENGGUNAAN MEDIA SOSIAL TIKTOK DALAM PEMBELAJARAN PPKN DI MASA PANDEMI COVID-19. 217

Sri Okta Puspita,S.Pd (SMP Negeri 1 Tanah) 
EFEKTIVITAS WHATSAPP DAN GOOGLE CLASSROOM DALAM PEMBELAJARAN DARING MATA PELAJARAN BAHASA INDONESIA 223

Siti Zukana, S.Pd. (MTs. N 1 Kudus)

EFEKTIVITAS PENGGUNAAN BERBAGAI MACAM SUMBER BELAJAR UNTUK MENINGKATKAN KETERCAPAIAN BELAJAR DI ERA PANDEMI COVID19.

Ndaru Kukuh Masgumelar, S.Pd., M.Pd (SMA Negeri 1 Bantur, Kab. Malang) 
x | Yang Terdepan dalam Menghadapi Pembelajaran Daring 


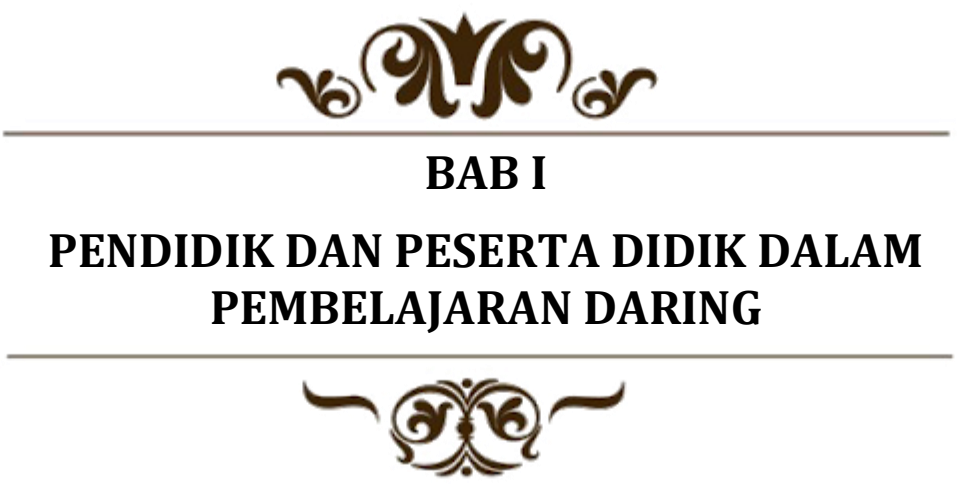

Yang Terdepan dalam Menghadapi Pembelajaran Daring | 1 
2 | Yang Terdepan dalam Menghadapi Pembelajaran Daring 


\title{
PEMBELAJARAN ONLINE: MEMBANGUN KETERLIBATAN GURU DAN SISWA
}

\author{
Dr. Anita, S.S., M.Pd. ${ }^{1}$ \\ (UIN Sultan Maulana Hasanuddin Banten)

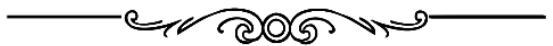

"Pembelajaran online pun membutuhkan peran guru sebagai mentor atau e-mentoring dalam rangka memberi umpan balik dan respon secara konsisten dan berkesinambungan kepada siswa"

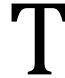
idak dapat dipungkiri bahwa masa pandemi covid19 yang menelurkan kebijakan pembelajaran online menciptakan fenomena-fenomena baru di Indonesia. Tampak bahwa era digital 4.0 belum sepenuhnya dapat diimplementasikan di negeri tercinta ini. Banyak kendala yang dihadapi guru maupun siswa terkait pemberlakuan pembelajaran online. Orang tua dan guru masih belum menyesuaikan dengan kebijakan pembelajaran online. Mereka merasa terkejut dengan kebijakan pemberlakuan mode belajar online. Banyak guru dan siswa yang tinggal jauh dari perkotaan
\end{abstract}

\footnotetext{
${ }^{1}$ Anita, lahir di Pandeglang pada tanggal 10 April. Ia menamatkan S1 di Fakultas Sastra Universitas Padjadjaran Bandung, S2 dan S3 di Universitas Negeri Jakarta. Saat ini tercatat sebagai dosen pada Program Studi Tadris Bahasa Inggris di Universitas Islam Negeri Sultan Maulana Hasanuddin Banten.
} 
mengalami kendala kesulitan mengakses jaringan internet. Dalam penelitian Ni Komang Astini, disebutkan $80 \%$ responden tidak dapat mengakses internet dengan baik dan mengeluhkan mahalnya biaya yang dikeluarkan untuk pembelian kuota (Suni Astini, 2020). Sementara di Kabupaten Lebak, Banten, orangtua tidak hanya mengeluhkan mahalnya kuota internet tetapi juga ketidakmampuannya dalam membelikan gadget android untuk memfasilitasi anak belajar secara online (https://www.republika.co.id/berita/qdz22i382/).

Berbeda dengan Indonesia, negeri tetangga, Singapur, telah menginvestasikan anggaran untuk TIK khususnya teknologi pendidikan melalui serangkaian rencana nasional selama 25 tahun terakhir untuk menunjang pembelajaran di perguruan tinggi maupun sekolah. Pemerintahnya berkolaborasi dengan kemitraan publik-swasta untuk membangun kesiapan pembelajaran jarak jauh/online. Dengan demikian mudah baginya menggunakan online learning sebagai respon terhadap pencegahan covid-19. Hal ini karena fasilitas sudah tersedia dan dapat dikembangkan, termasuk memberikan panduan kepada guru tentang bagaimana pembelajaran jarak jauh dikembangkan (Ndaruhutse et al., 2020).

Bangladesh, yang merupakan rekanan bisnis Singapur dalam bidang pembelajaran jarak jauh, sebagai respon terhadap pencegahan covid, memfokuskan pada program bimbingan orang tua dalam mendorong dan terlibat dalam kegiatan pembelajaran anak, termasuk menjalin kerja sama dengan enam jaringan telepon seluler untuk mendapat pemotongan biaya penggunaan data untuk materi pendidikan. Negara inipun menyiapkan program belajar bahasa Inggris bekerja sama dengan $\mathrm{BBC}$, melalui platform sesuler menyiarkan program pembelajaran audio dilengkapi dengan kuis 
dan situs web yang menyediakan materi-materi pelajaran, kuis, unduhan pembelajaran dan online interaktif sekaligus menseting liputan media cetak dan siaran televisi dengan informasi-informasi bertema "belajar yang menyenangkan" (Ndaruhutse et al., 2020).

Lain di luar negeri, lain di Indonesia upaya-upaya yang dilakukan pemerintah menghadapi kendala diantaranya dalam pemerataan jaringan internet untuk pembelajaran yang dilakukan secara online. Tidak hanya di wilayah terpencil, di provinsi yang sudah maju pun masih terkendala dengan jaringan internet (Kompas.com - 05/08/2020, 11:59 WIB). Sementara untuk mengatasi masalah kebutuhan kuota internet, menteri Pendidikan Nadiem Makarim mengijinkan digunakannya dana Bantuan Operasional Sekolah untuk pembelian kuota internet bagi guru dan siswa serta perlengkapan pencegahan covid lainnya seperti hansanitizer. Kemudian ditindaklanjuti dengan adanya bantuan pemerintah paket kuota data internet yang diatur dalam Peraturan Sekretaris Jendral Nomor 4 Tahun 2021 (Kemendikbud, 2021). Bantuan ini bertujuan sebagai penunjang lancarnya pelaksanaan kegiatan pembelajaran online pada masa pandemi covid-19. Bantuan paket kuota ini diperuntukan bagi semua jenjang peserta didik termasuk guru dan dosen. Untuk platform pembelajaran online, Nadiem menyerahkan sepenuhnya kepada pihak sekolah. Menurutnya sekolah lebih memahami kondisi ril sehingga bebas memilih aplikasi yang dapat digunakan dalam pembelajaran online. "Banyak platform yang bisa menjadi pilihan, kami beri kemerdekaan guru untuk menentukan yang terbaik," jelasnya (Kompas.com 02/08/2020, 18:30 WIB). Platform http://spada.kemendikbud.go.id / telah ditetapkan UNESCO sebagai platform pembelajaran online di Indonesia. 
Apapun platform atau media yang digunakan dalam pembelajaran, faktanya dalam kegiatan pendidikan, guru merupakan aktor utama yang menjadi ujung tombak terlaksananya pembelajaran yang ideal. Guru merupakan profesi profesional sekaligus sosial karena untuk menjadi guru setidaknya seseorang memiliki kualifikasi yang minimal dibuktikan dengan ijazah sarjana. Selain memiliki ijasah, menjadi guru membutuhkan panggilan jiwa dalam menjalankan profesinya. Dengan demikian menjadi guru artinya mempersiapkan diri berdialog dengan realita sosial untuk menjadi penemu solusi bagi tantangan dan permasalahan yang dihadapi demi mewujudkan citacita masyarakat. Sejarah Jepang menunjukkan pentingnya peran guru bagi tumbuh kembang generasi penerus. Saat Hirosima dan Nagasaki dijatuhi bom, ungkapan yang melegenda dari Kaisar Hirohito adalah "Berapa jumah guru yang tersisa”(Warsono, 2017).

Guru, dalam menjalankan profesinya, menjalin keterlibatan emosional antara dirinya dan siswa. Membangun keterlibatan emosional dapat dilakukan dengan lebih mudah dalam pembelajaran offline. Dalam kondisi bertatap muka, guru dapat menafsirkan komunikasi gerak tubuh siswa dan mudah mengidentifikasi masalah yang dihadapi siswa ketika pembelajaran berlangsung (Cragg et al., 2008) sehingga keterlibatan emosi antara guru dan siswa terbangun dengan baik. Namun, masa pandemi yang mengharuskan pelaksanaan pembelajaran secara online dengan menjadikan teknologi sebagai medianya, membutuhkan usaha yang tidak mudah untuk membangun keterlibatan emosional antara guru dan siswa. Lalu bagaimana membangun keterlibatan emosional antara guru dan siswa dalam pembelajaran online? Melalui profesionalismenya guru menghadirkan rasa empati melalui perhatian, keramahan, dan 
pemaklumannya terhadap kondisi siswa. Dalam pembelajaran online, keterlibatan antara guru dan siswa dibangun melalui sosial emosional,empati, dan dengan ekpresi ungkapan nada kata dan intonasi sapaan serta isyarat vokal (Nyanjom \& Naylor, 2020). Dengan perhatian guru, diharapkan memunculkan energi positif dalam diri siswa berupa rasa senang dan percaya diri sehingga siswa menjadi lebih ulet dan giat dalam mengerjakan tugas-tugas yang diberikan.

Tugas-tugas yang diberikan secara online, synchronous (media berbasis teks dengan respon yang tertunda seperti e-mail) maupun asynchronous (misalnya dalam obrolan yang langsung dan nyata seperti zoom/chat box) tentunya memiliki tujuan yang sama yaitu menjadikan siswa terlibat dalam materi yang diberikan. Siswa akan belajar bertanggung jawab dan mencari solusi, melatih berdisiplin serta menggali kemampuannya dalam berpikir.

Sebagaimana pembelajaran offline, pembelajaran online pun membutuhkan peran guru sebagai mentor atau e-mentoring dalam rangka memberi umpan balik dan respon secara konsisten dan berkesinambungan kepada siswa. Dengan demikian sekalipun pembelajaran dilaksanakan secara online, siswa tetap dapat membangun pengetahuannya sehingga diharapkan dapat menjadi siswa yang mandiri. Adam dan crew mengatakan bahwa e-mentoring merupakan alat untuk membantu siswa agar terlibat dalam pembelajaran online (Omar et al., 2012). E-mentoring akan menjadi sarana pendampingan ideal bagi siswa dalam melaksanakan pembelajaran online. Berbagai media dapat digunakan sebagai sarana e-mentoring, diantaranya email, WhatsAp, facebook, dan GoogleClassroom. Dengan media tersebut diharapkan siswa menemukan solusi atas permasalahannya dalam belajar 
sehingga memiliki kepercayaan diri untuk terlibat aktif dalam aktivitas pembelajaran yang pada akhirnya akan menumbuhkembangkan motivasi dan minatnya dalam belajar. Sebagai mentor, guru dapat memulai pelajaran dengan menyapa siswa, mengecek bahwa setiap siswa memiliki akses internet yang cukup untuk bergabung dalam pembelajaran online yang sedang berlangsung dan bahwa lingkungan sekitarnya mendukung proses pembelajaran online.

Namun ternyata e-mentoring ini bukanlah satu satunya solusi untuk mencapai pembelajaran yang baik mengingat bahwa tidak semua orang tua mampu membelikan gadget android bagi anaknya. Dibutuhkan kreatifitas guru dalam mensiasati masalah ini. Misalnya guru menyediakan kotak belajar di sekolah yang dibuka seminggu sekali sebagai media pengumpulan tugas dan mentoring offline bagi siswa. Dengan demikian pembelajaran jarak jauh tetap dapat dilaksanakan dan tentunya keterlibatan guru dan siswa tetap terjalin sebagaimana mestinya.

\section{DAFTAR PUSTAKA}

Cragg, C. E. (Betty), Dunning, J., \& Ellis, J. (2008). Teacher and Student Behaviors in Face-to-Face and On-Line $\backslash$ nCourses: Dealing with Complex Concepts. Journal of Distance Education, 22(3), 115-128.

Kemendikbud. (2021). Persekjen nomor 4 Tahun 2021 Tentang Petunjuk Teknis Penyaluran Bantuan Pemerintah Paket Kuota Data Internet Tahun 2021.

Ndaruhutse, S., Gibbs, E., \& Fitzpatrick, R. (2020). What are countries doing that already use remote 
learning extensively? What can we learn from them ?May, 37.

Nyanjom, J., \& Naylor, D. (2020). Performing emotional labour while teaching online. Educational Research, $\quad 00(00), \quad 1-17$. https://doi.org/10.1080/00131881.2020.183698 9

Omar, N. D. @, Hassan, H., \& Atan, H. (2012). Student Engagement in Online Learning: Learners Attitude Toward E-Mentoring. Procedia - Social and Behavioral Sciences, 67(November 2011), 464-475.

https://doi.org/10.1016/j.sbspro.2012.11.351

Suni Astini, N. K. (2020). Tantangan Dan Peluang Pemanfaatan Teknologi Informasi Dalam Pembelajaran Online Masa Covid-19. Cetta: Jurnal Ilmu Pendidikan, 3(2), 241-255. https://doi.org/10.37329/cetta.v3i2.452

Warsono, W. (2017). Guru: Antara Pendidik, Profesi, Dan Aktor Sosial. The Journal of Society \& Media, 1(1), 1. https://doi.org/10.26740/jsm.v1n1.p110

https://www.kemdikbud.go.id/main/blog/2020/03/ke mendikbud-bekerja-sama-dengan-operatortelekomunikasi-sukseskan-pembelajaran-dirumah 
10 | Yang Terdepan dalam Menghadapi Pembelajaran Daring 


\title{
GURU BERADA DI GARDA TERDEPAN MEWUJUDKAN PROGRAM PENDIDIKAN MERDEKA BELAJAR
}

\author{
Dr. Rif'iy Qomarullah.,S.Pd.,M.Or ${ }^{2}$ \\ Prof. Dr. Jonni Siahaan.,M.Kes.,AIFO \\ (Universitas Cenderawasih Papua)

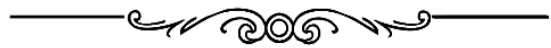

"Guru berada di garda terdepan dalam rangka menyiapkan generasi muda bangsa Indonesia yang berdaya saing tinggi di era digitalisasi"

\begin{abstract}
Curu adalah suatu pekerjaan profesional atau sebuah Jprofesi yang menuntut keahlian dan kompetensi tersertifikasi dari lembaga pendidikan yang berwenang. Pekerjaan sebagai guru mendapat tempat yang terhormat dalam kehidupan sosial-budaya dan perannya sangat dirasakan ditengah-tengah masyarakat. Dimana ada sekolah disitu pasti ada guru. Olehkarena itu, guru tidak terpisahkan dari keberadaan
\end{abstract}

\footnotetext{
${ }^{2}$ Rifiy Qomarullah. Lahir di Jepara 1 Januari 1986. Beliau Doktor dalam bidang Pendidikan Olahraga. Pendidikan Strata 1 Pendidikan Jasmani Kesehatan dan Rekreasi Universitas Negeri Surabaya/Unesa (2011). Pendidikan Strata 2 Ilmu Keolahragaan/Ikor Pasca Sarjana Universitas Negeri Semarang/UNNES (2013. Pendidikan Strata 3 Pendidikan Olahraga Pasca Sarjana Universitas Negeri Semarang/UNNES (2020).
} 
sekolah dan masyarakat di sekitar sekolah. Secara kelembagaan, sekolah dibangun olehkarena kebutuhan akan pendidikan generasi bangsa, dan tanpa pendidikan yang baik sangat tidak mungkin menghasilkan sumber daya manusia yang baik juga, bermutu dan memiliki kompetensi tinggi sebagaimana diharapkan di era saat ini dimana produk pendidikan selain memiliki kualifikasi juga kompetensi yang tinggi.

Produk pendidikan di era milineal ini secara khusus di Indonesia sangat diharapkan memperoleh sertifikat berupa ijazah dan kompetensi yang tersertifikasi keahliannya, sehingga mampu menciptakan lapangan pekerjaan (created the jobs), bukan hanya mencari pekerjaan. (seeked the jobd). Kompetensi yang terukur keahliannya sangat dibutuhkan mendukung dan beradaftasi dengan perkembangan revolusi industri 4.0 yang ditandai dengan lahirnya teknologi digital dan robotik. Sehubungan dengan kemajuan teknologi digital dan robotik ini, akan sangat banyak pekerjaan profesional yang hilang karena digantikan dengan pekerjaan lainnya yang lebih profesional, berdaya saing tinggi yang menyesuaikan dengan era digital dan kebutuhan manusia milineal

Profesi guru juga mendapat warning dengan munculnya teknologi digital pada semua aspek kehidupan manusia. Roda kehidupan manusia sepertinya saat ini sudah dikendalikan teknologi digital yang perkembangannya masif dan sistem kerjanya sangat cepat dan tepat dan manusia secara manual sudah tidak mampu lagi mengejar kecepatan kerja digital, bahkan kecepatan dan kecanggihannya digital akan semakin dahsyat di waktu yang akan datang. Fakta ini harus disikapi dengan baik dan profesional oleh semua pihak secara khusus para guru di sekolah, karena memiliki tanggungjawab untuk mencerdaskan 
kehidupan bangsa secara khusus mencerdaskan tunas bangsa, berdaya saing, berakhlak mulia sesuai dengan falsafah hidup bangsa dan negara Indonesia, agar tetap mencintai negaranya dan mampu menciptakan hal-hal baru dengan optimal memanfaatkan teknologi digital.

Lahirnya teknologi digital menjadi tantangan tersendiri bagi para guru di sekolah, karena sebagian pekerjaan guru bahkan kedepannya keseluruhan pekerjaan guru akan dapat diambil alih oleh teknologi digital dan robotik. Misalnya sumber ilmu pengetahuan saat ini dengan mudahnya diperoleh dengan bantuan digital. Kemampuan guru sangat terbatas untuk menguasai pengetahuan dan keterampilan atau keahlian, tetapi kemampuan digital sangat tidak terbatas untuk memberikan berbagai informasi yang dibutuhkan guna meningkatkan pengetahuan dan keterampilan.

Dunia kedepannya bukan tidak mungkin akan menghasilkan sumber daya manusia tanpa harus memiliki lembaga pendidikan yang megah dan berbiaya tinggi operasionalnya. Belajar dari rumah secara daring (online) untuk bidang keahlian tertentu dapat diwujudkan untuk menciptakan manusia yang cerdas dan ahli dalam bidangnya. Fenomena ini harus dapat dicermati dan disikapi oleh Pemerintah dan pemangku kepentingan yang berkaitan dengan dunia pendidikan. Kondisi ini telah disikapi Presiden RI Bapak Ir. H. Joko Widodo bersama Menteri Pendidikan dan Kebudayaan Riset dan Teknologi, Bapak Nadiem Anwar Makarim dengan mengimplementasikan program merdeka belajar pada semua jenjang pendidikan.

Program merdeka belajar sangat diharapkan mulai tahun 2021 dapat secara serentak diwujudkan di lembaga pendidikan yang ada di nusantara ini. Dasar pemikiran inilah, pada Hari Pendidikan Nasional 
(Hardiknas) tanggal 2 Mei 2021 mengambil tema "Serentak Bersama Wujudkan Merdeka Belajar". Program merdeka belajar ini akan dapat melakukan loncatan-loncatan dalam pengembangan dan beradaftasi dengan kemajuan teknologi digital yang sangat canggih dan akan semakin canggih dimasa akan datang. Program merdeka belajar ini menjadikan guru sebagai penggerak. Artinya peran guru tetap strategis dalam menghasilkan SDM unggul ditengah kondisi kemajuan digital. Sehebat apapun teknologi digital tetap akan membutuhkan guru, olehkarena ada kondisi belajar yang tidak dapat diberikan dengan teknologi digital meskipun secara teori terkait apapun dapat diperoleh dengan mudah dengan bantuan digital.

Keberhasilan dalam proses belajar di sekolah, sangat tergantung pada ketersediaan guru yang profesional, sebab tanpa guru itu, sangat tidak mungkin dapat dikelola segala hal terkait dengan keberlangsungan proses belajar yang baik, misalnya anak didik dapat berpartisipasi secara maksimal. Bagaimana proses belajar dapat berlangsung dengan baik dan seluruh anak didik dengan senangnya dapat mengikuti pelajaran, sangat tergantung pada guru. Proses belajar yang menarik dan menyenangkan merupakan syarat utama untuk memperoleh hasil belajar yang optimal baik berupa pengetahuan, keterampilan dan pembentukan kharakter, sebagai domain yang ditetapkan dalam kurikulum sekolah. Dalam konteks ini guru berada di garda terdepan selama proses belajar di sekolah.

Proses belajar sesungguhnya terjadi dalam 3 (tiga) lingkungan pendidkan yaitu formal (sekolah/lembaga pendidikan), informal (dalam keluarga) dan non formal (masyarakat). Peran guru sangat strategis dalam ketiga lingkungan pendidikan tersebut, secara khusus di 
sekolah yang menjadi tugas pokoknya. Kondisi inilah yang menyebakan guru mendapat tempat terhormat di masyarakat, menjadi soko guru atau panutan di masyarakat, bahkan guru diberi kesempatan berperan langsung maupun tidak langsung dalam roda kehidupan di masyarakat, khususnya di lingkungan sekolah dimana guru tersebut menjalankan profesinya.

Pendidikan adalah usaha sadar dan sistematis yang melibatkan tiga faktor utama yang menjadi lingkungan pendidikan yaitu keluarga, sekolah dan masyarakat. Ketiga lingkungan pendidikan ini harus bersinergismembangun sumber daya manusia yang unggul. Olehkarena itu ketika negara melakukan perubahan dalam penyelenggaraan pendidikan seperti program merdeka belajar harus bersinergis dengan pola pikir keluarga, sekolah dan masyarakat, agar segala kebijakan terkait merdeka belajar dapat diwujudkan.

Program merdeka belajar pada intinya ingin melakukan loncatan peningkatan peranan lembaga pendidikan meningkatkan kualitas sumber daya manusia yang mampu beradaptasi, berdaya saing tinggi mengikuti kemajuan teknologi digital yang sangat cepat. Program merdeka belajar memberi kebebasan kepada guru dan murid untuk mengelola kurikulum sekolah yang berdampak pada peningkatan kemampuan dan kompetensi anak didik. Dunia seakan terbuka lebar tanpa sekat-sekat dengan adanya kemajuan digital saat ini. Ada banyak pekerjaan yang sudah dikerjakan secara profesional harus diganti dan diubah menjadi bentuk yang lain sebagai akibat dari tuntutan digital. Meskipun demikian, peran guru masih berada digarda terdepan untuk menciptakan SDM unggul.

Bangsa dan Negara Jepang, ketika Kota Hiroshima dan Nagasaki hancur lebur karena di bom tentara sekutu pada tahun 1945 , upaya yang pertama dilakukan 
Negara Jepang adalah menghitung jumlah guru yang tersisa untuk diselamatkan dengan cara diberi fasilitas oleh negara untuk belajar di negara lain guna mempersiapkan SDM unggul Jepang setelah proses pemulihan Negara Jepang pasca bom tersebut. Peran guru dalam konteks ini berada di garda terdepan untuk menghasilkan SDM unggul Jepang di kemudian hari, dan sudah terbukti saat ini di era milineal ini, Jepang menjadi salah satu negara Macan Asia.

Bagaimana terobosan Indonesia terkait dunia pendidikan di era kepemimpinan Presiden RI Bapak Ir. H. Joko Widodo?. Sejak tahun 2015 ada 6 (enam) program prioritas Presiden RI bapak Ir. H. Joko Widodo dalam bidang pendidikan yakni; Program Indonesia pintar (PIP), Penguatan Pendidikan Karakter (PPK), Revitalisasi Pendidikan Vokasi, Zonasi Pendidikan, Pemajuan Kebudayaan, dan Digitalisasi Sekolah. Ke-6 program prioritas pendidikan ini menunjukkan bahwa peran guru berada di garda terdepan dalam rangka untuk mewujudkan nawacita program prioritas bidang pendidikan di Indonesia.

Penyelenggaraan pendidikan di sekolah di era digital harus bersinergis dengan program nawacita Pemerintah dalam bidang pendidikan. Salah satu produk dari nawacita bidang pendidikan tersebut adalah program merdeka belajar, yang menunjukkan adanya perbedaan signifikan dengan kondisi riil sebelumnya, baik dari sisi proses belajar, ketersediaan media belajar, sumber materi ajar, target belajar dan lain-lain. Olehkarena itu sangat tidak mungkin dilaksanakan proses belajar biasa-biasa saja tanpa target belajar yang jelas sebab semuanya sudah harus terukur target belajar seperti apa yang ingin diwujudkan dari setiap proses belajar berlangsung. Termasuk di tengah kondisi pandemi Covid-19, proses belajar daring tetap saja diharapkan 
dapat berlangsung di rumah-rumah anak didik dan berharap dapat mencapai target belajar sesuai dengan tuntutan kurikulum dan kemajuan zaman.

Dalam program merdeka belajar, guru sebagai penggerak harus dapat mengelola proses belajar dengan baik di sekolah dan menjadi tanggungjawab guru, baik proses belajar di dalam maupun di luar kelas (outing class). Prof. Dr. Agus Kristiyanto.,M.Pd dalam face booknya tanggal 8 Mei 2021 menyatakan bahwa merdeka itu sebuah suka cita tetapi bukan suka-suka. Merdeka belajar adalah hak setiap individu, tapi sayangnya tidak setiap individu memiliki kemampuan layak untuk mengisinya, bahkan mungkin memilih tidak belajarpun dianggap bagian dari merdeka belajar. Gaya bebas bukan berarti bebas menggunakan gaya renang apapun. Dalam konteks ini guru harus berada digarda terdepan untuk mewujudkan proses belajar yang berkualitas

Program merdeka belajar memberi kebebasan kepada guru mendisain dan mewujudkan tujuan yang diharapkan dari dunia pendidikan saat ini. Pemerintah RI bersama Mendikbud-Ristek pada tahun 2021 menetapkan delapan prioritas merdeka belajar yaitu; pembiayaan pendidikan melalui KIP (Kartu Indonesia Pintar), digitalisasi sekolah, prestasi dan penguatan kharakter, guru penggerak, kurikulum baru, revitalisasi pendidikan vocasional, kampus merdeka dan pemajuan kebudayaan dan bahasa. Kedelapan program prioritas program merdeka belajar menjadi pedoman untuk melakukan loncatan dalam bidang pendidikan.

Program merdeka belajar lebih menfokuskan pada kebebasan guru dalam mendisain program pengajaran. Sejauhmana guru memiliki kemampuan mendisain program pengajaran dapat dijadikan sebagai indikator mengukur kualitas guru, setidaknya ada beberapa hal 
yang dapat digunakan untuk mengukur profesionalisme guru saat ini antara lain; guru memiliki kompetensi dan keahlian dalam bidangnya, guru mampu memodifikasi bahkan menciptakan sesuatu yang baru mengikuti kemajuan teknologi digital saat ini dan kedepannya. Guru dapat mengelola kelas dengan baik, di lapangan maupun di dalam ruangan kelas. Guru mampu menyiapkan diri akan tanggungjawabnya seperti; merencanakan proses belajar, media belajar termasuk sumber belajar. Guru dapat menguasai teknologi informasi seperti digital secara mumpuni karena besar kemungkinan kedepannya akan memadukan proses belajar tatap muka (offline) dan dalam jaringan (online).

Pendidikan pada hakikatnya memiliki tiga unsur penting yaitu mendidik/membimbing, mengajar, dan melatih. Pendidikan itu eratkaitannya dengan kehidupan masa depan setiap insan manusia. Apabila pendidikan berlangsung biasa-biasa saja atau lebih ekstrim lagi asal-asal saja maka akan tercipta sumber daya manusia yang tidak siap menghadapi era mileneal yang syarat akan kompetensi yang tersertifikasi keahliannya.

Keberhasilan menyelenggarakan pendidikan dengan pendekatan program merdeka belajar secara profesional di Indonesia menjadi tanggungjawab semua elemen bangsa tanpa kecuali, dan guru berada digarda terdepan, olehkarena dari sinilah akan lahir anak bangsa Indonesia yang sehat dan bugar, memiliki kecerdasan dan keahlian/kompetensi, berahklak mulia, jujur dan bangga sebagai anak-anak Indonesia, berdaya saing tinggi, dan lain-lain. Mereka sebagai tunas atau generasi penerus bangsa untuk menjaga keuntuhan Negara Kesatuan Republik Indonesia (NKRI). 


\title{
PERAN GURU TERHADAP PESERTA DIDIK DI MASA PANDEMI COVID-19
}

\author{
Muhammad Yusuf, S.Pd.I,.M.Pd ${ }^{3}$ \\ (STAI DDI Kota Makassar/Bosowa School Makassar) \\ -4 @OS 以ூ-
}

\begin{abstract}
"Profesi sebagai guru tidaklah mudah karena membutuhkan keahlian tertentu, apalagi kalau menjadiseorang guru yang professional harus betul-betul menguasai seluk-beluk pendidikan dan pengajaran sehingga dapat mendidik dengan baik"
\end{abstract}

\section{A. Guru}

\section{Pengertian guru}

uru adalah seseorang yang mengajarkan ilmu Jpengetahuan kepada peserta didik, baik itu terkait ilmu agama ataupun ilmu umum. Guru merupaka seseorang yang selalu ditiru oleh para peserta didik baik tingkal laku, maupun kepribadian lainnya. Olehnya itu,

3 Penulis lahir di Botto (Bone, Sul-Sel), 03 Juli 1985. Penulis merupakan Pengajar di Bosowa School Makassar dan Dosen di STAI DDI Makassar dalam bidang ilmu Pendidikan Agama Islam (PAI), penulis mengambil jurusan Bahasa Arab di LIPIA (2004-2008), menyelesaikan gelar Sarjana S1 Pendidikan Agama Islam di IAI AL Aqidah Jakarta ( 2008 ), dan menyelesaikan gelar Magister pendidikan Agama Islam di UIN Alauddin Makassar ( 2016 ), sekarang sedang menmpuh Progran Doktoral dibidang konsentarsi Pendidikan dan Keguruan. 
menjadi guru itu tidaklah mudah karena semua tingkah lakunya akan menjadi teladan bagi peserta didiknya. Guru adalah sebuah profesi yang membutuhkan keahlian tertentu sehingga guru ini tidak bisa dilakukan oleh sembarang orang selain orang yang mempunyai keahlian dibidang pendidikan.

Ramayulis memberikan pendapat bahwa guru adalah seseorang yang bertanggung jawab memberikan bimbingan kepada peserta didik untuk menjadi manusia yang dapat memanusiakan manusia, sehingga yang menjadi tugas utama seorang guru adalah mendidik, mengajar, membimbing, mengarahkan, melatih, menilai, dan mengevaluasi peserta didiknya (Ramayulis 2013 ).

Dalam peraturan pemerintah Republik Indonesia Nomor 74 Tahun 20 tentang guru di jelaskan bahwa guru adalah pendidik propesional dengan tugas utama mendidik, mengajar, membimbing , mengarahkan, melatih, menilai, mengevaluasi peserta didik pada pendidikan usia dini dalam jalur pendidikan formal, pendidikan dasar dan menengah ( PP RI No 74 Tahun 2008 tentang guru ). Guru merupakan salah satu faktor yang sangat penting dalam proses pembelajaran, bagaimanapun bagusnya kurikulum tanpa didukung oleh kemampuan seorang guru dalam melakukan pengajaran atau dalam mengimplementasikan pembelajaran makan itu akan tidak bermakna.

Dari uraian diatas dapat dsimpulkan bahwa guru adalah seseorang yang bertanggung jawab terhadap pengembangkan ilmu pengetahuan peserta didik baik itu pengetahuan yang terkait dengan kebutuhan jasmani maupun yang terkait dengan kebutuhan rohani. Namun perlu diketahui bahwa tetap orang tua menjadi penanggung jawab utama dalam pendidikan seorang anak, karena itu adalah kodrat sebagai orangtua. 


\section{Tugas dan fungsi guru}

Profesi sebagai guru tidaklah mudah karena membutuhkan keahlian tertentu, apalagi kalau menjadiseorang guru yang professional harus betulbetul menguasai seluk-beluk pendidikan dan pengajaran sehingga dapat mendidik dengan baik.

Guru mempunyai banyak tugas, baik itu tugas yang terkait dengan dinas maupun luar dinas sebagai bentuk pengabdian. Apabila dikelompokkan, maka terdapat tiga jenis tugas seorang guru yaitu tugas dalam bidang profesi, tugas kemanusiaan, dan tugas dalam bidang kemasyarakatan.

a. Tugas guru sebagai profesi meliputi mendidik, mengajar, melatih. Mendidik berarti meneruskan dan mengembangkan nilai-nilai hidup. Mengajar berarti meneruskan dan mengembangkan ilmu pengetahuan, keterampilan dan teknologi. Sedangkan melatih berarti mengembangkan keterampilan-keterampilan peserta didik.

b. Tugas guru dalam bidang kemanusiaan disekolah harus menjadikan dirinya sebagai orang tua kedua. Seorang guru harus mampu menarik simpati sehingga menjadi idola para peserta didiknya.

c. Tugas guru dibidang kemasyarakatan, masyarakat menempatkan guru sebagai orang yang terhormat dilingkungannya karena dari seorang guru diharapkan memperoleh ilmu pengetahuan. Ini menandakan bahwa seorang guru berkewajiban mencerdaskan bangsa menunju pembentukan manusia Indonesia yang seutuhnya yang berdasarkan pancasila (Abd.Rahman Getteng 2014). 
Sebagai guru profesional haruslah mengerjakan tugas-tugasnya dengan baik sesuai dengan kapasitas sebagai pendidik sehingga apa yang dicita-citakan oleh system pendidikan Negara kita bisa tercapai secara maksimal. Walaupun memang tugas guru sangat berat tapi itulah konseskuensi yang harus dikerjakan oleh seorang guru, ketika seseorang sudah memilih profesi menjadi seorang guru, maka semua tugas-tugas sebagai guru harus dikerjakan secara professional.

\section{B. Peran Guru terhadap peserta didik di Masa Pandemi}

Di masa pandemi covid 19 ini, peran guru terhadap peserta didik sangat besar khususnya dalam proses pembelajaran daring. Oleh karena itu, beberapa peran guru terhadap peserta didik di masa pandemi ini akan penulis uraikan, diantaranya :

\section{Guru sebagai motivator ( penyemangat)}

Guru menjadi motivator atau penyemangat terhadap peserta didik dalam melaksanakan pembelajaran selama masa pandemic ini, jadi guru senantiasa memberikan motivasi-motivasi kepada peserta didik sebelum masuk pembelajaran ini. Hal ini agar peserta didik tetap bersemangat dalam mengikuti pembelajaran walaupun pembelajarn melalui daring atau online.

Perlu diketahui bahwa peran guru yang harus melekat pada dirinya adalah guru harus dapat menjadi motivator kepada peserta didiknya, sehingga selalu mendorong peserta didiknya agar besemangat dalam mengikuti pembelajaran. Keterampilan seorang guru dalam memotivasi peserta didik dapat menyebabkan peserta didik bersemangat dalam mengikuti pembelajaran (Soetjipto dan Raflis Kosasi 2009) . 


\section{Guru sebagai konselor}

Pembelajaran yang dilakukan oleh sekolah dimasa pandemic Covid 19 yaitu pembelajaran daring atau online. Peran guru sebagai konselor terhadap peserta didik sangat terlihat, dimana guru senantiasa memberikan bimbingan dan konseling kepada peserta didik. Konselor ini merupakan salah satu tugas guru, sebab gurulah yang lebih memahami peserta didiknya mulai dari karakternya, kepribadiannya bahkan kebiasaan-kebiasaanya sehinga dalam memberikan bimbingan sangatlah mudah.

James P.Adam menjelaskan bahwa konseling itu adalah pertalian timbal balik antara dua orang dimana seorang konselor membantu orang lain dalam hal ini konseling supaya dia dapat memahami dirinya dalam kaitannya dengan masalah kehidupan yang dihadapi oleh soseorang dari waktu ke waktu ( Kompas.Com 2021). Selain itu, Bimo Walgito juga mengatakan bahwa konseling adalah bantuan seseorang kepada orang lain untuk memecahkan masalah kehidupannya, bisa melalui wawancara atau dengan cara-cara lain yang bisa menyelesaikan masalah kehidupannya.

\section{Guru Sebagai mitra orangtua dalam mendidik dirumah}

Guru senantiasa melakukan komunikasi intens dengan orang tua dalam melaksanakan pembelajaran daring di masa pandemic, sehingga pembelajaran bisa berjalan dengan lancar sesuai yang diharapkan guru. Jadi dalam pembelajaran daring ini dibutuhkan kerjasama guru dan orangtua, guru senantiasa memberikan informasi-informasi kepada orang tua terkait materi pembelajaran dan kegiatan-kegiatan yang akan dilakukan oleh sekolah, sebaliknya orangtua senantiasa memberikan informasi ke guru terkait perkembangan peserta didik dirumah. 


\section{Guru sebagai agen penyuluh dalam standar kesehatan}

Guru sebagai agen penyuluh terhadap standar kesehatan bagi peserta didik dimasa pandemi, disini guru senatiasa mengingatkan peserta didik untuk menjaga kesehatan, memakai masker, menjaga jarak menjaga imunitas diri dan menggunakan handsanitaizer. Hal tersebut dilakukan oleh guru sebelum memulai pembelajaran. Guru senantiasa memberikan edukasi mengenai pentingnya menjaga kesehatan kepada peserta didik.

\section{Peran guru dalam sosialisasi informasi dan tekhnologi}

Guru berperan penting dalam mensosialisasikan informasi dan tekhnologi kepada peserta didik khususnya bagi peserta didik yang belum terlalu menguasai tekhnologi dalam melakukan pembelajaran. Dalam pembelajaran daring terdapat beberapa kendala yang sering dialami oleh peserta didik, baik itu kendala dalam hal-hal yang terkait dengan penggunaan media pembelajaran seperti zoom, google meet, whatshaap, edmodo, google class room dan lain-lain maupun yang terkait dengan cara-cara mengoperasikan Learning Management system (LMS ) yang dilaksanakan oleh sekolah masing-masing. Maka dalam hal ini, guru sangat berperang penting dalam mengajarkan dan mengarahkan peserta didik dalam mengunakan tekhnologi dalam pembelajaran daring di masa pandemic.

\section{DAFTAR PUSTAKA}

Getteng, Abd. Rahman,(2014), Menuju Guru Profesional dan Ber-Etika, Yogyakarta :Graha Guru, 
Http://www.kompas.com/chrysn.com/54f92956a3331 $16 \mathrm{e} 0$

Peraturan Pemerintah Republik Indonesia Nomor 74 Tahun 2008 tentang Guru bab I pasal I

Ramayulis,(2013), Profesi dan Etika Keguruan, Jakarta: Kalam Mulia

Soetjipto dan Raflis Kosasi,(2009), Profesi Keguruan, Jakarta : PT Rineka Cipta 
26 | Yang Terdepan dalam Menghadapi Pembelajaran Daring 


\title{
PENDIDIKAN KARAKTER KEPADA ANAK DALAM PERSPEKTIF AL QUR'AN DAN HADITS
}

\author{
Arif Friyadi, Lc, M.Ag ${ }^{4}$ \\ (IAIN Kudus) \\ 4 @O( ) -
}

"Kelembutan budi sangat penting untuk membentuk karakter akhlak seorang anak. Anak yang lemah lembut terdidik dari keluarga yang lemah lembut"

\begin{abstract}
Dembangunan dalam kancah nasional sesuai yang ditulis dalam sebuah RPJP (Rencana Pembangunan Jangka Panjang) tahun 2005-2025 (UU no. 17 tahun 2007) di antaranya adalah mengimplementasikan akhlak mulia dalam kehidupan masyarakat, berbudaya dan beradab berdasarkan falsafah Pancasila. Amanah undang-undang di atas dapat kita pahami bahwa pembangunan bukan hanya bersoal pada pembangunan fisik, infrastruktur dan tekhnologi, namun pada
\end{abstract}

\footnotetext{
${ }^{4}$ Arif Friyadi, Lc, M.Ag adalah penulis nasional yang beberap buku novelnya seperti "Mengapung Bersama Nil", "Sepuluh Peminang Bidadari" telah dicetak secara nasional. Sekarang penulis bekerja sebagai Dosen IAIN Kudus Fakultas Ushuluddin. Penulis lahir pada tanggal 19 Juni 1986. Menempuh pendidikan S.1 di Al Azhar Universtiy Cairo, S.2 di UIN Walisongo Semarang. Beberapa tulisan artikelnya juga sudah dimuat di Jurnal bersinta 2 dan 3.
} 
dasarnya pembangunan akhlak mulia adalah aspek paling penting dalam pembangunan itu sendiri. Dengan akhlak mulia negara mampu menjadi bangsa yang berkarakter dan disegani seluruh negara. Namun jika akhlak tidak terbangun, terjadikan dekadensi moral yang sewaktu-waktu akan menghancurkan pembangunan yang telah ada. $\mathrm{Di}$ sinilah Islam menggariskan pendidikan berkarakter untuk anak dengan tujuan sebagai pembentukan karakter bangsa. Al Qur'an dan hadis secara general menjelaskan ada empat hal yang diterapkan orang tua terhadap anaknya; 1. Kelembutan 2. Suri tauladan yang baik, 3. Lingkungan yang baik,

Salah satu dasar penting dalam pendidikan karakter adalah pendidikan akhlak pada anak. Pendikan yang benar pada seorang anak merupakan pendidikan yang menekankan akhlak yang baik dalam seorang anak. Sehingga dengan pendidikan karakter berupa akhlak yang baik maka meminimalisir kecenderungan berbuat buruk saat anak tumbuh dewasa. Namun sebaliknya, pendidikan akhlak yang buruk dari orang tua akan membentuk karakter anak yang cenderung pada keburukan dan kejahatan. Menurut Pusat Bahasa (Depdiknas) karakter berarti sebagai berikuti; "bawaan, hati, jiwa, kepribadian, budi pekerti, perilaku, personalitas, sifat, tabiat, temperamen, watak. Karakter mengacu kepada serangkaian sikap (attitude), perilaku (behavior), motivasi (motivation), dan keterampilan (skill)".

Pembentukan karakter anak menurut al Qur'an dan hadits dapat terbentuk sejak dini. Usia dini menurut peribahasa adalah bagaikan mengukir di atas batu. Ibarat kertas putih, anak dapat kita tulisi apa saja. Tulisan buruk maka yang terbaca di kertas itu adalah buruk. Namun jika yang kita tulis itu adalah hal yang 
baik, kertas itu secara tidak langsung akan menerangkan kebaikan. Untuk itu Islam sangat menekankan pentingnya pendidikan karakter anak usia dini sebagai pembentukan karakter bangsa menuju arah kemajuan mendatang.

\section{Dasar Pendidikan Akhlak Menurut al Qur'an dan Hadis}

Berangkat dari tujuan utama pendidikan akhlak yang telah dijelaskan di atas, di sini jelas bahwa peran al Qur'an dan hadis sebagai dasar utama ummat Islam sangat dibutuhkan untuk membentuk karakter akhlak anak. Dasar urgensitas akhlak dalam hadis dicerminkan dalam sabda Nabi; "Sesungguhnya aku diutus hanyalah untuk menyempurnakan akhlak yang baik," (HR Ahmad) Adapun dasar-dasar akhlak yang tertuang dalam al Qur'an dan hadis adalah sebagai berikut;

\section{Al Qur'an}

Al Qur'an adalah kalam Allah Swt. yang diturunkan kepada Nabi Muhammad Saw. melalui malaikat Jibril. Isi dari al Qur'an sebagai ajaran pokok yang dapat dikembangkan dalam seluruh aspek kehidupan. Tidak terkecuali akhlak. Secara spesifik Al Qur'an tidak menggariskan bagaimanakah akhlak yang baik, namun dengan ayat serta sejarah yang terkandung di dalamnya, kita dapat berkesimpulan jika al Qur'an adalah sumber ajaran akhlak untuk seluruh manusia. Termasuk pendidikan akhlak anak kepada orang tua adalah kisah nabi Ibrahim:

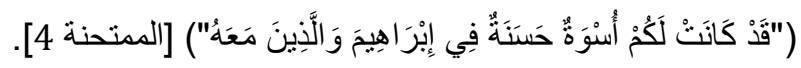

Artinya:"Sesungguhnya telah ada suri tauladan yang baik bagimu pada Ibrahim dan orang-orang yang bersama dengan dia" (al Mumtahanah 4) 
Hal yang dapat kita ambil dari cerita nabi Ibrahim adalah kelembutan budi Ibrahim menghadapi sang ayah, Adzar. Meski berbeda keyakinan namun beliau tetap menghormatinya, mendoakannya serta selalu mengajaknya dalam Islam. Berkata Ibrahim, "Wahai bapakku, mengapa kamu menyembah sesuatu yang tidak mendengar, tidak melihat, dan tidak dapat menolong kamu sedikit pun? Wahai bapakku, sesungguhnya telah datang kepadaku sebagian ilmu pengetahuan yang tidak datang kepadamu. Maka ikutilah aku, niscaya aku akan menunjukkan kepadamu jalan yang lurus." Namun sayangnya ajakan Ibrahim ini tidak diikuti dengan ketundukan sang ayah hingga dia mati dalam keadaan kafir.

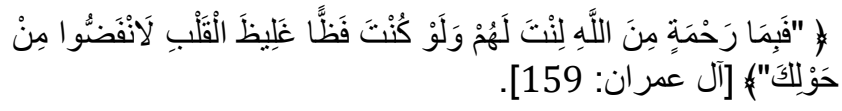

Artinya: "Maka disebabkan rahmat dari Allah-lah kamu berlaku lemah lembut terhadap mereka. Sekiranya kamu bersikap keras lagi berhati kasar, tentulah mereka menjauhkan diri dari sekelilingmu. Karena itu ma'afkanlah mereka, mohonkanlah ampun bagi mereka, dan bermusyawaratlah dengan mereka dalam urusan itu[246]. Kemudian apabila kamu telah membulatkan tekad, maka bertawakkallah kepada Allah. Sesungguhnya Allah menyukai orang-orang yang bertawakkal kepada-Nya." (Ali Imran: 159)

Kelembutan budi nabi terpancar dari seluruh aspek kehidupan yang dicontohnya oleh Rasulullah kepada ummatnya. Baik dalam perkataan, perbuatan, ketetapan dan akhlak. Beberapa contoh kelembutan nabi saat beliau berdakwah ke Kota Thaif. Bukannya mendapat perlakuan baik, namun malah beliau dilempari batu oleh penduduknya. Sontak Jibril datang kepada beliau dan mengatakan, jika mau aku akan timpakan gunung ini kepada mereka. Namun beliau tidak mau. Beliau 
balik mendoakan orang Thaif semoga Allah memberikan hidayat kepada mereka.

Kelembutan budi sangat penting untuk membentuk karakter akhlak seorang anak. Anak yang lemah lembut terdidik dari keluarga yang lemah lembut. Namun anak yang cenderung kasar, nakal dan bandel juga tercermin dari didikan orang tua terhadapnya. Perlunya mencontoh nabi dalam kehidupan akan mencerminkan sikap lembut dan akhlak yang mulia.

\section{Hadis}

Terdapat banyak hadis penting yang menekankan pendidikan akhlak terhadap anak. Di antara hadis itu adalah;

$$
\begin{array}{r}
\text { (ما من شيء في الميزان أنقل من حسن الخلق)) رواه الترمذي (2002)، وابن حبان (506/12) }
\end{array}
$$

"Tidaklah ada yang lebih berat dalam timbangan amal nanti dari akhlak yang baik." (HR. Imam Turmudzi No.2002, Ibnu Hibban 506)

$$
\text { ("حسن الخلق وحسن الجوار يعمران الديار ويزيدان في الأعمار") }
$$

Artinya: "Akhlak yang mulia, bertetangga yang baik akan menambah keberkahan umur" (HR. Imam Ahmad)

$$
\text { (أكمل المؤمنين إيمانًا أحسنهم خلقًا) رواه الترمذي (1162) }
$$

Artinya: "Paling sempurnanya keimanan seorang mu'min adalah orang yang paling baik akhlaknya. (HR. Imam Turmudzi no.1162)

Dari tiga hadis di atas dapat kita simpulkan, karakter pendidikan paling utama adalah bagaimana seorang guru atau orang tua menekankan kepada akhlak yang baik. Secara tidak langsung guru atau orang tua menjadi cerminan anaknya. 


\section{Bentuk pendidikan moral yang dapat kita ambil dari al Qur'an dan hadis;}

\section{Kelembutan}

Kelembutan adalah hal yang paling urgen dalam kehidupan ini. Akhlak yang mulia tercermin dari kelembutan budi dan kesantunan pekerti seorang. Dalam pendidikan kelembutan Ummul Mu'minin Aisyah meriwayatkan hadis sebagai berikut;

$$
\text { "أن الله يحب الرفق فى الأمر كله" }
$$

Artinya: "sesungguhnya Allah menyukai kelembutan dalam setiap hal."

Kelembutan dapat kita tanamkan dalam kehidupan sehari-hari terhadap anak. Jika seorang anak kita ingatkan, maka baiknya kita ingatkan dengan kelembutan. Jika kita ingatkan dengan cara kasar, bukannya ia mau melaksanakan peringatan kita, justru mereka akan balik meniru.

Dalam hadis lain rasul juga menjelaskan:

$$
\text { من يحرم الرفق يحرم الخير }
$$

"Barang siapa yang menutupi kelembutan (megharamkan kelembutan) maka dia ditutupi dari kebaikan."

Dari ummul Mu'minin 'Aisyah Ra.

$$
\text { "إذا أر اد الله عز وجل بأهل بيت خبرا أدخل عليهم الرفق" ' }
$$

Jika Allah menginginginkan suatu keluarga baik maka Allah akan memasukkan kelembutan di hati mereka." (HR. Imam Ahmad dalam Musnadnya (24427)

\section{Suri tauladan yang baik}

Sebagai orang tua wajib menjadi suritauladan baik untuk pendidikan karakter anak-anaknya. Tidak layak sebagai orang tua melarang anaknya merokok 
sementara dirinya sendiri mengkonsumsinya. Seorang salaf dulu dalam pendidikan anak mengatakan,

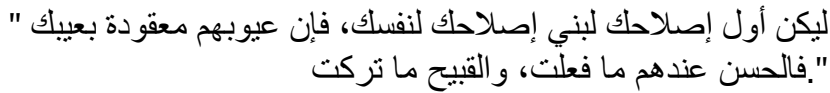

Artinya: "Hal yang pertama dalam perbaikan akhlak adalah perbaikan akhlak diri sendiri."

Orang tua merupakan kunci dari akhlak seorang anak. Baik buruknya anak tergantung pendidikan orang tua kepadanya. Di sini lah selayaknya seorang wajib menjadi suri tauladan yang baik untuk murid serta anaknya.

\section{Lingkungan yang baik}

Setelah melaksanakan pendidikan yang tertuang di atas, lingkungan baik dalam struktur masayarakat sekitar juga menentukan akhlak seorang anak. Tidak jarang beberapa kasus ada anak yang terdidik dari keluarga yang baik, namun karena pergaulan lingkungan yang kurang baik menjadikannya mengalami dekadensi moral. Mari sebagai orang tua yang tugas utama kita selain menafkahi keluarga tugas utama kita adalah menjaga keluarga kita dari pergaulan yang salah. Lingkungan yang membentuk karakter anak kita harus kita perhatikan terus. Bisa jadi lingkungan itu adalah lingkungan yang kurang baik hingga anak kita terpengaruh dan masuk dalam keburukan mereka. 
34 | Yang Terdepan dalam Menghadapi Pembelajaran Daring 


\title{
MENGAJARKAN BERPUASA DENGAN CINTA PADA ANAK USIA DINI DI BULAN RAMADHAN PADA MASA NEW NORMAL
}

\author{
Dita Lestari, M.Psi. ${ }^{5}$ \\ (IAIN Bengkulu)

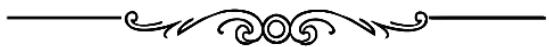

“Orangtua perlu memberikan sounding kepada anak mengenai apa itu berpuasa beserta manfaat yang akan Ia dapatkan. Terutama di masa new normal ini dimana anak-anak memiliki keterbatasan ruang gerak sehingga ia merasa bosan di rumah"

$\mathrm{B}$

erpuasa di bulan ramadhan adalah kewajiban umat islam sesuai ketetapan Allah pada rukun islam yang keempat. Berpuasa ini bermakna menahan haus, lapar, dan hawa nafsu. Hawa nafsu ini bermakna menjaga diri dari lisan dan pikiran yang negatif sehingga bagi manusia yang dapat menerapkannya maka Allah janjikan kembali fitrah. Artinya Allah bersihkan dosa, hati dan pikirannya. Motivasi puasa umat Islam adalah tampak pada hikmah puasa itu sendiri, termasuk latihan

\footnotetext{
${ }^{5}$ Penulis lahir di Bengkulu, 23 Juni 1993. Penulis merupakan dosen IAIN Bengkulu jurusan Pendidikan Islam Anak Usia Dini. Penulis menyelesaikan gelar Sarjana Psikolog di Universitas Negeri Padang (2011-2015), sedangkan Gelar Magister Profesi Psikologi Pendidikan di Universitas Gadjah Mada (2016-2019).
} 
disiplin jiwa, moral, serta untuk mendidik diri agar menjadi orang yang bertakwa.

Berpuasa ini hukumnya wajib bagi umat islam yang telah baligh. Baligh dalam hukum islam merupakan istilah yang menunjukkan bahwa seseorang telah mencapai kedewasaan (Lestari, 2005). Selanjutnya hikmah puasa juga terangkum dalam firman Allah surat al-Baqarah [2]:183 yang artinya, hai orang-orang yang beriman, diwajibkan atas kamu berpuasa sebagaimana diwajibkan atas orang-orang sebelum kamu agar kamu bertakwa. Namun, agar individu mampu berpuasa 1 hari penuh tentu perlu berlatih. Oleh karena itu, diharapkan kepada orangtua dapat melatih anak berpuasa sebelum berusia baligh.

Melatih anak berpuasa merupakan tantangan tersendiri bagi orangtua karena proses ini menjadi penentu apakah anak akan mencintai bulan puasa sebagai iman atau hanya sebagai kewajiban saat di rumah saja. Oleh karena itu orangtua perlu berlatih mengenalkan puasa beserta maknanya sebagai bentuk iman dan taqwa kepada Allah SWT. Ilmu psikologi memperkenalkan teori perilaku atau behavioristik dalam membentuk perilaku anak yang diharapkan. Teori behavior memperkenalkan konsep stimulus dan respon. Sifat dari stimulus adalah netral sedangkan respon sifatnya bervariasi karena berdasarkan pengalaman dari masing-masing individu. Skinner memperkenalkan konsep tambahan pada teori behavioristik yaitu adanya reinforcement (reward) dan punishment (hukuman). Kedua hal ini diharapkan dapat memberikan sumbangan yang lebih efektif dalam membentuk perilaku anak yang diinginkan.

Pada tulisan kali ini kita akan membahas konsep membentuk perilaku berpuasa di bulan ramadhan dengan cinta pada anak usia dini. Menurut Stenberg 
(1988), cinta adalah bentuk emosi manusia yang dalam dan paling diharapkan. Cinta ini dilengkapi dengan perasaan dekat dan mengenal orang yang dicintai. Anak mengenal cinta pertama kali adalah cinta kepada Ibu dan Ayah. Adanya kelekatan, kehangatan dan saling membutuhkan antar satu sama lain. Objek cinta ini akan terus berkembang seiring dengan bertambahnya usia anak. Oleh karena itu, pentingnya orang tua memberikan cinta yang cukup kepada anak karena ini menjadi sumber kepercayaan diri dan nilai yang akan menjadi prinsip hingga Ia dewasa.

Di Indonesia, orangtua seringkali berlomba memberikan hadiah atau iming-iming kepada anakanak yang berhasil menajalankan ibadah puasa. Pemberian hadiah ini juga dilakukan oleh anggota keluarga yang lain seperti kakek-nenek, om-tante dan lain-lain. Hadiah yang diberikan seringkali tidak sesuai dengan usia, ada yang memberi uang 100 ribu sehari puasa, ada yang memberikan mainan, tas, sepatu dan lain-lain. Konsep ini tanpa disadari telah menanamkan nilai puasa yang berorientasi pada hadiah pada anak. Hal ini sesuai dengan konsep teori behavioristik sebagaimana eksperimen yang dilakukan oleh Skinner pada tikus (Cervone, Daniel dan Lawrence, 2012). Skinner meletakkan 2 ekor tikus di kandang dengan mengkondisikan jika lampu hijau dihidupkan dan tikus menekan tuas yang ada di kandang maka ia akan mendapatkan makanan, namun jika lampu merah menyala dan tikus menekan tuas di kandang maka ia akan merasakan sentruman ringan. Setelah beberapa hari maka tikus tersebut berhenti menekan tuas saat lampu merah menyala. Hal ini menunjukkan bahwa tikus-tikus ini telah belajar bahwa Ia akan mendapatkan makanan (reward) jika lampu hijau menyala namun Ia akan disentrum ringan jika menekan tuas saat lampu merah menyala (punishment). 
Oleh karena itu dapat disimpulkan, pada anak yang terbiasa distimulasi dengan hadiah maka responnya adalah melaksanakan puasa hanya pada saat dapat hadiah. Sebaliknya jia ia tidak mendapatkan hadiah maka perilaku unutk berpuasa melemah atau bahkan hilang. Terutama sifat dasar manusia adalah tidak pernah puas sehingga nominal atau harga dari hadiah harus terus meningkat untuk memotivasinya melaksanakan puasa. Fenomena yang muncul adalah anak hanya akan berpuasa saat mendapat hadiah dan konsep ini dibawa hingga Ia Baligh atau dewasa. Dapat kita saksikan di bulan ramadhan banyak anak remaja hingga dewasa yang makan, minum, dan merokok di tempat umum. Hal ini disebabkan karena makna berpuasa adalah untuk meningkatkan keimanan kepada Allah SWT belum tersampaikan dengan baik.

Berdasarkan penjelasan di atas maka pentingnya orang tua mengajarkan anak usia dini berpuasa dengan cinta adalah mutlak. Orangtua perlu memberikan sounding kepada anak mengenai apa itu berpuasa beserta manfaat yang akan Ia dapatkan. Terutama di masa new normal ini dimana anak-anak memiliki keterbatasan ruang gerak sehingga ia merasa bosan di rumah. New normal adalah perubahan perilaku atau kebiasaan untuk tetap menjalankan aktivitas seperti biasa namun dengan selalu menerapkan protokol kesehatan di tengah pandemi COVID-19. Oleh karena itu orang tua perlu kreatif untuk membuat jadwal anak dalam mengeksplor lingkungan supaya dapat berpuasa dengan baik serta tetap menerapkan protokol kesehatan terutama sama bepergian di luar rumah. Orangtua juga wajib menjelaskan kepada anak manfaat berpuasa yang akan Ia dapatkan. Menurut Maqashidus Shaum, Izudin bin Abdis Salam (Febriansyah, 2020) menyimpulkan manfaat berpuasa dalam 7 hal: Pertama, meningkatkan ketakwaan yang membuat hati menjadi 
tenang. Kedua, menghapus dosa. Ketiga, mengendalikan hawa nafsu. Keempat, memperbanyak sedekah. Kelima, Menjaga kesehatan. Keenam, meningkatkan rasa syukur. Ketujuh mencegah diri dari perbuatan maksiat. Diharapkan orang tua dapat menjelaskan ketujuh manfaat berpuasa ini sesuai dengan bahasa anak dan berikan contoh yang mudah dimengerti. Teladan terbaik adalah adalah orang tua sehingga apa yang dilakukan oleh orang tua akan anak tiru. Oleh karena itu, orang tua harus konsisten dalam menunjukkan perilaku yang sesuai atas apa yang disampaikan kepada anak.

Setelah anak diberikan pemahaman maka perkenalkan langsung secara praktek. Anak dibangunkan untuk sahur dengan penuh kasih sayang lalu diberikan makanan favorit saat berbuka puasa. Selain itu, orang tua perlu memberikan apresiasi seperti pujian dan pelukan hangat disaat anak berhasil bangun saat sahur dan lain-lain. Berikan apresiasi ini setiap saat agar tumbuh rasa bahagia dan penghargaan pada diri anak. Selain itu, ajarkan anak berpuasa secara bertahap, artinya anak belajar berpuasa tidak langsung sehari penuh melainkan dimulai dari 3-4 jam terlebih dahulu. Waktu berpuasa ini dapat ditingkatkan setiap minggu dan merupakan hasil kesepakatan orangtua dan anak. Menurut Hartatik (2019) berikut beberapa cara mengenalkan dan melatih anak-anak untuk berpuasa, diantaranya:

\section{Memberi Teladan}

Anak-anak membutuhkan figur teladan, dan teladan paling dekat bagi anak adalah orangtua. Saat orangtua menjalankan ibadah puasa, pasti anak akan bertanya apa itu puasa, mengapa ayah dan ibu tidak makan, dan sebagainya. Hal itu akan menimbulkan rasa penasaran anak, sehingga anak ingin mencobanya. Di usia yang masih mudaanak bisa dengan mudah meniru perilaku 
orang-orang di sekitarnya, sehingga memberikan contoh lebih efektif dibandingkan sekedar memberikan instruksi.

\section{Tidak memaksa anak}

Perlu diingat bahwa melatih anak berpuasa Ramadhan tidak sama dengan mewajibkan mereka berpuasa. Telah jelas bahwa Islam sendiri tidak menghendaki adanya unsur paksaan dalam mendidik anak. Bila orangtua memaksa anak berpuasa di luar batas kemampuan si anak, ibadah yang sejatinya indah malah akan menjadi rasa susah.

\section{Memulai secara bertahap}

Melatih anak berpuasa sebaiknya dilakukan secara bertahap dengan mempertimbangkan kondisi dan kemampuan anak. Bisa dimulai dengan puasa setengah hari (orang jawa menyebutnya puasa mbedug), berbuka saat dhuhur lalu melanjutkan kembali puasanya sampai maghrib. Kalau anak sudah merasa kuat, boleh mencoba berpuasa sehari penuh hingga bedug maghrib.

\section{Memperhatikan kualitas makanan}

Biar bagaimanapun anak-anak masih dalam masa pertumbuhan, maka sangat penting menyediakan menu sahur dan berbuka dengan asupan makanan yang sehat bernutrisi. Apalagi jika menu yang disajikan tersebut adalah kegemaran si anak, pasti akan menambah semangat anak dalam berpuasa.

\section{Membuat kegiatan yang menyenangkan}

Biasanya anak mulai rewel pada jam-jam tertentu. Karenanya perlu dilakukan upaya untuk mengalihkan perhatiannya, menyibukkan mereka agar lalai dari rasa lapar dan dahaga dengan kegiatan yang menarik dan menyenangkan. 


\section{Memberikan motivasi dan pujian pada anak}

Terlepas dari berapa jam anak sudah puasa atau berapa hari anak mengikuti puasa, alangkah baiknya orangtua memberikan penghargaan atau apresiasi kepada anak setelah ia menjalankan puasa. Tidak harus selalu dengan hadiah berupa materi, bisa juga dengan memuji dan mengatakan bahwa ia anak yang hebat, hal tersebut sudah dapat menambah semangat anak untuk ikut menjalankan ibadah puasa lagi dan lagi.

\section{DAFTAR PUSTAKA}

Lestari, Puji Ningrum. 2005. Hukum Islam. Bandung: Logos Wacana Ilmu.

Sternberg, R.J. 1988. The Psychology of Love. USA: Yale University

Febriansyah. 2020. Manfaat Puasa Ramadhan Menurut Dalil-Al.Qur'an dan Hadis Nabi. https://tirto.id/manfaat-puasa-ramadhanmenurut-dalil-al-quran-hadis-nabi-e56L

Hartatik, S. 2019. Mengajarkan Anak Berpuasa Sejak Dini. https://sdmujahidinwns.sch.id/read/247/mengajarkan-anakberpuasa-sejak-dini

Cervone, Daniel dan Lawrence A. Pervin. 2012. Kepribadian: Teori dan Penelitian (edisi. 10)buku 2, terj. Aliya Tusyani, et.al, Jakarta, Salemba Humanika. 
42 | Yang Terdepan dalam Menghadapi Pembelajaran Daring 


\title{
"GURU IDOLA" DI TENGAH PANDEMI COVID-19 DALAM KACAMATA SISWA DI DAERAH TERPENCIL
}

\author{
Susana Labuem, M.Pd ${ }^{6}$ \\ (Universitas Pattimura PSDKU ARU)

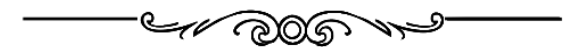

“Teknologi hanya sebuah alat. Dalam hal membuat siswa bekerja sama dan menjadikan mereka termotivasi, gurulah yang paling utama. Seorang guru yang baik yang bisa menerima bayaran nol dan membantu anak-anak berkembang secara moral, emosional, fisik, karakter dan pengetahuan tak hanya sebatas sebagai idola tetapi secara harafiah adalah malaikat".

$\mathrm{P}$ andemi Covid-19 tidak hanya menyerang negara Indonesia namun juga melanda dunia dan kemudian merubah tatanan kehidupan bermasyarakat. Keberadaan Covid-19 menuntut masyarakat untuk memberhentikan aktivitas di luar rumah yang

6 Penulis lahir di Longgar, 07 Oktober 1990. Penulis merupakan Dosen Pendidikan Matematika pada Universitas Pattimura Program Studi Di Luar Kampus Utama (PSDKU) di Kabupaten Kepulauan Aru. Penulis menyelesaikan Pendidikan Strata I di Universita Pattimura Program Studi Pendidikan Matematika pada tahun 2013. Selanjutnya, penulis menyelesaikan Pendidikan Strata II di Universitas Negeri Malang Jurusan Matematika pada tahun 2019. 
semestinya dilakukan seperti pada hari-hari biasa. Masyarakat harus menjaga jarak aman atau disebut dengan physical distancing, keadaan dimana orangorang dikarantina dan diisolasi di dalam rumah masingmasing termasuk dalam melaksanakan pekerjaan sehingga setiap individu yang rentan tidak akan tertular virus Covid-19. Apabila masyarakat ingin keluar rumah untuk memenuhi kebutuhan pokok seperti membeli sesuatu untuk kebutuhan sehari-hari, masyarakat diwajibkan menggunakan masker dan tentu dengan menjaga jarak aman dengan orang lain. Begitu pun bagi masyarakat yang melakukan perjalanan lintas kota atau daerah, wajib melakukan karantina atau isolasi mandiri selama 14 hari begitu tiba di tempat tujuan.

Pelaksanaan karantina dan isolasi mandiri yang dihimbau oleh pemerintah tentu tidak hanya berimbas pada pekerjaan masyarakat saja, akan tetapi juga berdampak pada sistem pendidikan yang mesti tetap berjalan. Pandemi Covid-19 telah mempengaruhi sistem pendidikan di seluruh dunia, yang mengarah ke penutupan (diliburkan) sekolah maupun perguruan tinggi. Proses pembelajaran yang biasanya dilaksanakan di dalam ruang kelas pada lingkungan sekolah kini berubah menjadi dengan belajar di dalam rumah.

Berdasarkan Surat Edaran Nomor 4 Tahun 2020 tentang Pelaksanaan Kebijakan Pendidikan dalam masa darurat penyebaran virus Covid-19, Mendikbud menghimbau agar semua lembaga pendidikan tidak melakukan proses pembelajaran secara langsung atau tatap muka, melainkan harus dilakukan secara tidak langsung atau jarak jauh. Dengan adanya himbauan tersebut membuat semua lembaga pendidikan mengganti metode pembelajaran yang digunakan yaitu menjadi online atau dalam jaringan (daring). 
Tidak dapat dipungkiri bahwa pembelajaran secara daring seperti yang diinstruksikan oleh Mendikbud menimbulkan berbagai macam pro dan kontra dalam masyarakat khususnya minimnya pengetahuan teknologi guru, siswa dan orang tua mengenai pengaplikasian metode daring ini. Meskipun guru harus memperkaya dan meng-upgrade keilmuan, tetapi tuntutan untuk menguasai berbagai aplikasi yang mendukung pembelajaran daring dengan cepat tidaklah semudah yang dibayangkan. Begitu juga dengan siswa dan mahasiswa, mungkin untuk mahasiswa, siswa SMA/ SMK dan SMP mempelajari dan menguasai aplikasi daring ini dengan cepat dapat dilakukan. Akan tetapi untuk para siswa SD, hal ini dirasa cukup sulit dilakukan. Akhirnya, mau tidak mau orang tua diminta untuk terlibat dalam pembelajaran daring ini.

Orang tua dengan latar belakang pendidikan tinggi akan dengan mudah beradaptasi dengan pembelajaran secara daring. Sedangkan orang tua dengan latar belakang pendidikan rendah, akan pasrah-pasrah saja jika selama berminggu-minggu anak tidak dapat mengikuti proses pembelajaran bahkan tidak mendapat nilai sama sekali. Bahkan ada pula siswa yang terkendala tidak memiliki alat komunikasi yang memadai dikarenakan kondisi ekonomi keluarga yang kurang mampu.

Lemahnya jaringan internet juga merupakan kendala yang sering dialami oleh para guru maupun dosen. Latar belakang siswa dan mahasiswa juga harus menjadi perhatian penting dimana siswa dan mahasiswa berasal dari latar belakang yang berbeda-beda, ada yang berasal dari keluarga broken home, lingkungan tempat tinggal yang tidak baik, serta anak-anak dari keluarga yang kurang mendukung kegiatan pendidikan. Hal ini tentunya menjadi tantangan berat bagi guru maupun 
dosen dalam pengaplikasian metode pembelajaran daring. Pada saat pembelajaran konvensional saja ada sebagian siswa dan mahasiswa yang mau memperhatikan dan berkontribusi saat pembelajaran berlangsung. Sebagian lagi kurang bahkan tidak berkontribusi, bagi mereka sudah mau dan dapat bersekolah saja sudah sangat bersyukur. Oleh karena itu guru harus bekerja ekstra keras agar siswa mau mengikuti model kelas daring.

Kondisi ini tentu saja memberikan dampak pada kualitas pembelajaran. Siswa dan guru maupun mahasiswa dan dosen yang sebelumnya berinteraksi secara langsung dalam ruang kelas sekarang harus berinteraksi dalam ruang virtual yang terbatas. Guru dituntut memberikan pengajaran yang baik, menciptakan suasana yang kondusif untuk belajar dan secara kreatif dan inovatif menggunakan media belajar yang menarik agar siswa dapat memahami materi pembelajaran dan tujuan pembelajaran dapat tercapai. Selain guru dan dosen, siswa maupun mahasiswa dituntut untuk selalu menyesuaikan diri dengan setiap perkembangan teknologi yang merupakan ciri khas dari revolusi industri 4.0 .

Era revolusi industri 4.0 menjadi isu akhir-akhir ini, bahkan menjadi isu Internasional. Era dimana keterampilan dan kepemimpinan seseorang menjadi kemampuan untuk bertahan dalam Era Transformasi Teknologi yang begitu cepat. Era yang mempengaruhi seluruh sudut kehidupan termasuk pendidikan. Kemajuan pendidikan menjadi tolak ukur atau ujung tombak kemajuan bangsa, karena lewat pendidikan kita dapat meningkatkan kemampuan sumber daya manusia.

Dunia pendidikan harus senantiasa menyesuaikan perkembangan teknologi terhadap usaha dalam 
meningkatkan mutu pendidikan, terutama penyesuaian penggunaan teknologi informasi dan komunikasi bagi dunia pendidikan khususnya dalam proses pembelajaran. Implementasi pemanfaatan teknologi informasi dan komunikasi dalam dunia pendidikan salah satunya dapat diwujudkan melalui pembelajaran dalam jaringan (daring). Guru yang menguasai dan memanfaatkan teknologi dalam proses pembelajaran tak jarang diberi "label" sebagai "guru idola" oleh para siswa khususnya siswa yang bersekolah di daerah perkotaan. Pertanyaan menarik namun kritis kemudian muncul, yaitu "kalau demikian adanya, apakah para guru yang mengabdi di daerah terpencil (pedesaan) yang tak tersentuh sarana pendukung berbasis teknologi tak layak diberi "label" sebagai "guru idola"?

Guru idola, sebutan yang diberikan kepada guru yang memiliki hal-hal spesial yang belum tentu dimiliki oleh guru yang lain. Label sebagai guru idola ini bergantung dari kacamata setiap orang yang melihat dan kemudian menyimpulkannya. Untuk guru yang mengabdi di daerah pedesaan atau di daerah terpencil yang jauh dari segala hal yang bersentuhan dengan teknologi, tidaklah mesti menjadi penyebab guru-guru ini tidak dapat disebut sebagai guru idola. Guru yang mencintai tugas dan panggilannya, guru yang total berdedikasi dalam segala keterbatasan yang ada, guru yang menjadi panutan bagi para siswanya, guru yang loyal dalam memberikan ilmu dan mempersiapkan masa depan bagi para siswanya, guru yang mampu bertumbuh dan berkembang bersama para siswanya dalam semua keterbatasan yang dijumpai, semua mereka layak untuk diberi label sebagai "guru idola". Lantas seperti apa sosok "guru idola" dalam kacamata siswa yang ada di daerah pedesaan di kabupaten kepulauan Aru provinsi Maluku? 
Kabupaten kepulauan Aru dengan ibu kota kabupaten yaitu Dobo, merupakan salah satu kabupaten di bagian timur Indonesia tepatnya di provinsi Maluku. Salah satu karakteristik kepulauan Aru secara geografis, yaitu memiliki 187 pulau yang terdiri dari 89 pulau yang berpenghuni dan 98 pulau yang tidak berpenghuni. Terdapat 119 desa yang tersebar di 89 pulau yang berpenghuni tersebut. Berdasarkan data dari Dinas Pendidikan Dan Kebudayaan Kabupaten Kepulauan Aru, di setiap desa telah didirikan sekolah baik itu PAUD, TK, SD, SMP maupun SMA/SMK. Hal ini merupakan salah satu langkah strategis untuk mewujudkan tujuan negara, yaitu mencerdaskan kehidupan bangsa dan juga memberikan hak warga negara sebagaimana yang tertuang dalam pasal 31 ayat 1 UUD 1945, yaitu setiap warga negara berhak mendapatkan pendidikan.

Kecamatan Aru Selatan merupakan satu dari 10 kecamatan yang ada di kabupaten kepulauan Aru dan posisinya yang paling jauh dari pusat kota kabupaten. Di kecamatan ini, ada beberapa desa yang memiliki SMA termasuk SMA persiapan yang baru dibuka desa Laininir. Sebagai sekolah rintisan tentunya ada banyak hal yang mesti disiapkan. Bangunan sekolah yang layak, status sekolah harus sah secara administrasi maupun prosedural, sarana prasarana pendukung kegiatan pembelajaran, tenaga pendidik dan kependidikan yang kompeten di bidangnya masing-masing, semua itu menjadi hal mutlak yang harus dipersiapkan. Akan tetapi, fakta yang ada belum sesuai dengan ekspektasi yang diharapkan. Sebagai sekolah baru, SMA Negeri Laininir masih mengalami keterbatasan sarana dan prasarana, buku-buku penunjang proses pembelajaran dan lebih khusus lagi minimnya tenaga guru yang berkompeten di bidangnya. 
Tahun ajaran 2020/2021 merupakan tahun ketiga berdirinya sekolah ini. Sekolah dengan jumlah siswa kurang lebih 50 orang berbanding terbalik dengan tenaga guru yang hanya 4 tenaga honorer sekolah ditambah dengan kepala sekolah yang berstatus PNS. Perbandingan jumlah guru dan siswa masih jauh dari kategori ideal. Persoalannya tak hanya sebatas itu. Empat orang tenaga guru honorer sekolah ini merupakan putra-putri asli dari desa Laininir. Mereka dengan tulus mendedikasikan dirinya untuk mencerdaskan generasi bangsa yang ada di desa Laininir kabupaten kepulauan Aru. Totalitas dedikasi mereka berbanding terbalik dengan upah yang harusnya mereka terima setiap bulan. Gaji para guru honor ini akan dibayarkan ketika para siswa sudah mengumpulkan uang SPP. Namun jika tidak, para guru ini akan tetap mengajar berbulan-bulan tanpa mendapatkan upah. Namun mereka tetap total berkontribusi dalam pengabdiannya. Selain mengajar di sekolah sesuai dengan waktu efektif sekolah, para guru ini juga seringkali memberikan pelajaran-pelajaran tambahan di rumah secara gratis kepada para siswa.

Ketika kabupaten kepulauan Aru dinyatakan masuk zona merah berdasarkan peta zonasi penyebaran Covid19, proses pembelajaran di SMA Negeri Laininir tidak dapat dilaksanakan secara online karena tidak ada jaringan internet maupun listrik yang masuk di desa Laininir. Para guru honor di sekolah ini dengan setia mendatangi rumah para siswa untuk memberikan materi pelajaran. Sungguh, totalitas dalam pengabdian tanpa menuntut upah atas semua dedikasi yang tulus untuk setiap anak bangsa. Seorang guru yang baik yang bisa menerima bayaran nol dan membantu anak-anak berkembang secara moral, emosional, fisik, karakter dan pengetahuan, tak hanya sebatas sebagai idola tetapi secara harafiah adalah malaikat. 
$\mathbf{5 0}$ | Yang Terdepan dalam Menghadapi Pembelajaran Daring 


\section{MELAWAN MOMOK GURU MATEMATIKA DI MASA PANDEMI: SEBUAH PENGALAMAN}

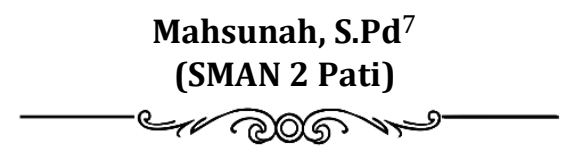

"Penggunaan metode pembelajaran yang tepat dan asyik ini bisa didiskusikan sesama guru"

Tndonesia menginformasi kasus pertama infeksi virus corona penyebab Covid-19 pada awal Maret 2020 (Rizal, 2020). Pandemi ini berpengaruh ke seluruh aspek kehidupan, baik aspek sosial, ekonomi bahkan pendidikan. Munculnya beberapa kosa kata yang trend di masa pendemi ini antara lain new normal, work from home dan juga school from home.

Sejak adanya pandemi, dampak yang dirasakan di dunia pendidikan adalah munculnya pembelajaran daring/online atau istilahnya school from home. Pembelajaran yang biasanya dilakukan secara tatap

${ }^{7}$ Penulis adalah guru Matematika di SMA N 2 Pati. Lahir di Rembang, 20 Pebruari 1969. Menyelesaikan Pendiikan Dilpoma III dari IKIP Semarang (sekarang Universitas Negeri Semarang) pada tahun 1991. Pendidikan Sarjana diperoleh dari UT ( Universitas Terbuka ) pada tahun 1996 
muka di kelas, harus dilakukan secara online dari rumah masing-masing. Dari sini sudah mulai muncul beberapa hambatan terkait dengan jaringan dan kemampuan SDM guru dalam mengoperasikan teknologi informasi. Namun jika diamati akhirnya juga memberikan efek positif, bahwa dengan adanya pembelajaran daring guru dan siswa dituntut untuk bisa mengikuti teknologi informasi dalam e-learning. Pada akhirnya, pembelajaran daring/online ini memunculkan kreativitas-kreativitas pada guru dalam menyampaikan materi. Termasuk guru-guru matematika, yang merupakan pelajaran yang "susah" dan "menakutkan" yang selama ini menjadi momok bagi siswa.

\section{Matematika sebagai Momok}

Matematika merupakan salah satu pelajaran wajib yang diajarkan di sekolah. Namun demikian faktanya hampir sebagian pelajar tidak menyukai atau menganggap matematika sebagai salah satu pelajaran yang "menakutkan". (Ovinka, 2019) . Stereotip matematika sebagai momok bagi siswa bukanlah hal baru. Tidak sedikit siswa yang mengakui bahwa matematika adalah pelajaran yang menegangkan dan menakutkan. Dampaknya, guru matematikapun sering dianggap killer. Sehingga wajar kalau banyak siswa yang tidak suka dengan mata pelajaran matematika. Dan pada akhirnya siswa cenderung malas untuk belajar matematika. Ketika jam matematika siswa mulai stres, ngantuk, ,mules, dan mengeluh saat harus mengerjakan soal. Namun, dibalik fakta-fakta tersebut masih ada siswa yang suka matematika, justru sangat menggemari mata pelajaran matematika.

Ada pengalaman menarik ketika ada siswa yang curhat (saat saya pertama kali mengajar di kelasnya) . "Sejak SD guru matematika saya galak bund ( sebutan bunda sering kali diberikan kepada saya)". Pengalaman 
tersebut mendorong saya untuk berfikir dan berusaha mencari cara merubah matematika menjadi pelajaran yang disukai. Sebagai guru matematika, sudah selayaknya saya ingin menjadikan matematika sebagai pelajaran yang menyenangkan. Pada masa pandemi seperti sekarang ini, upaya tersebut rasanya agak sulit, namun sulit bukanlah tidak bisa.

\section{Mengajar dengan Hati}

Matematika adalah pelajaran yang membutuhkan bimbingan guru. Sebelum pandemi, pelajaran matematika diajarkan secara offline dengan bimbingan guru, dan pendampingan. Pada kondisi seperti itu saja banyak siswa yang merasa kesulitan. Memasuki masa pandemi, maka semua pembelajaran beralih ke pembalajaran online (daring). Ini menjadi tantangan berat bagi guru matematika. Membayangkan pelajaran yang dianggap sulit harus diajarkan secara daring saja rasanya berat. Maka tidak mengherankan ketika awalawal harus mengajar daring menjadi sesuatu yang tidak mudah khususnya bagi guru matematika, bahkan sempat stress mencari cara bagaimana mengajarkan matematika yang mengasikkan.

Tidak sedikit guru matematika yang merasa kesulitan mencari cara mengajar yang enak dan mengasyikkan, supaya siswa bisa menerima pelajaran dengan baik. Berbagai metode digunakan untuk mengajarkan matematika. Ada yang menggunakan Youtube, Gogle clas room, Whatsapp grup, dan ada yang menggunakan Microsof Team. Walaupun variasinya berbeda, semua tujuanya sama yaitu untuk menyampaikan materi secara baik ke siswa. SMA Negeri 2 Pati Jawa Tengah, tempat saya mengajar menggunakan Microsoft Team (MT) untuk pembelajaran. Pembelajaran dengan MT memberikan peluang dan ruang kreativitas guru dengan penggunaan 
berbagai variasi. Ada fitur share screen yang memudahkan kita untuk menggunakan video atau menggunakan penjelasan word (dengan lambang equasi matematika), yang memungkinkan siswa untuk langsung berinteraksi dengan tanya jawab.

Rasanya kita tidak perlu ideal dengan berharap semua siswa kita harus bisa. Di masa pandemi ini, semua bisa kita buat mudah kok, yang terpenting adalah siswa bisa menerima dengan baik materi yang kita sampaikan. Penggunaan media hendaknya sudah kita sepakati dengan siswa. Selain itu, sekiranya siswa membutuhkan konsultasi guru harus siap bahkan saya terbuka 24 jam untuk para siswa yang mau bertanya dan berkonsultasi masalah pelajaran, baik melalui whatsapp, telpon, telegram. Ini menjadi salah satu upaya untuk memberikan kenyamanan bagi mereka belajar matematika.

Penggunaan metode pembelajaran yang tepat dan asyik ini bisa didiskusikan sesama guru. Pelajaran matematika membutuhkan banyak latihan. Maka salah satu kesepakatan yang bisa kita buat adalah pada saat pelajaran matematika setelah penyampaian materi pada pagi hari, kemudian dilanjutkan dengan pembahasan soal, kemudian pada malam hari kita mengadakan latihan atau posttes secara online melalui e-learning untuk mengetahui sejauh mana pemahaman siswa. Kesepakatan ini mendapatkan respon yang cukup baik dan hasil post test pun cukup baik, karena dengan sistem online ini siswa bisa langsung mengetahui hasil testnya. Orang tuapun dapat memantau perkembangan pembelajaran anaknya. Menurut saya cara ini cukup efektif, karena memungkinkan kita untuk bisa menilai secara langsung kemampuan siswa dan biasanya setelah ulangan siswa yang belum menguasai materi akan berkonsultasi secara langsung melalui whatsapp. 
Dengan demikian saya bisa mengetahui seberapa jauh kemempuan siswa saya.

Metode ini sudah kami terapkan sejak awal pandemi dan hasilnya cukup baik. Siswa menyerap materi dengan baik dan dekat (tidak merasa takut) dengan guru matematika. Bahkan tidak sedikit orang tua yang mengikuti pembelajaran mendampingi anaknya merasa senang dengan metode ini. Ini saya ketahui, ketika suatu saat ada orang tua yang langsung menghubungi saya dan mengucapkan terima kasih telah memberikan bimbingan kepada anaknya sehingga anaknya bisa menyerap pelajaran matematika dengan baik.

Keinginan untuk menghilangkan momok kalau matematika adalah pelajaran yang paling tidak menyenangkan bahkan matematika adalah mata pelajaran yang paling dibenci siswa, rasanya bisa kita lakukan dengan metode pembelajaran yang baik. Selain dengan metode yang menarik, guru juga harus dapat memberikan motivasi kepada siswa. Motivasi dalam pembelajaran matematika adalah usaha-usaha untuk menyediakan kondisi-kondisi sehingga seseorang terdorong untuk belajar lebih baik, dan mempengaruhi siswa sehingga pada diri siswa timbul dorongan untuk belajar, sehingga diperoleh pengertian, pengetahuan, sikap dan penguasaan kecakapan, agar lebih dapat mengatasi kesulitan-kesulitan (Defantri, n.d.).

Pendekatan kepada siswa amatlah penting. Di sekolah guru adalah orang tua kedua bagi siswa, maka sebagai orangtua hendaknya guru bisa dekat dengan siswa sebagaimana anak dan ibu atau bapaknya. Pembelajaran matematika harus menggunakan pendekatan dari hati ke hati. Pendekatan dari hati ke hati ini akan menimbulkan kenyamana bagi siswa, yang pada akhirnya juga memunculkan kedekatan antara siswa dengan guru. Ketika siswa merasa nyaman 
dengan gurunya maka dia akan berusaha menyenangi mata pelajaran yang diajarkan gurunya. Dengan metode pelajaran yang menyenangkan maka kita akan bisa menepis anggapan matematika adalah momok bagi siswa.

Dalam setahun terakhir ini kita bahkan tidak pernah sekalipun tatap muka dengan siswa, bahkan saya mengajar di kelas $\mathrm{X}$ belum tahu secara langsung siswa kita, dan kita tetap harus mengenal para siswa satu per satu pada saat daring. Maka saat daring itulah kesempatan kita mengenal siswa kita lebih dekat. Salah satu cara yang saya lakukan adalah setiap pembelajaran daring kita harus bisa mengenal dengan cara MT meminta menghidupkan kameranya. Dan yang paling utama yang saya lakukan setiap saat adalah pendekatan dengan hati sehingga ada kedekatan antara guru dengan siswa.

Menjadi kewajiban bagi saya, seorang guru matematika untuk menghilangkan momok matematika sebagai mata pelajaran yang menyeramkan, dan guru matematika sebagai guru killer. Caranya adalah dengan menerapkan metode pembelajaran yang sesuai dengan kemampuan dan kondisi sisswa, serta suasana yang menyenangkan. Belajar tidak harus di kelas, tidak harus sama persis plek dengan buku. Guru hendaknya juga memberikan ruang kepada siswa untuk eksplorasi dengan mengembangkan pendapat dan kemampuannya sendiri. Guru harus mengikuti perkembangan IT, bersosial media serta mengikuti perkembangan siswa generasi $\mathrm{Z}$ supaya lebih kreatif dalam pembelajaran online.

Pendekatan dari hati ke hati antara guru dan siswa mari menjadi metode yang ampuh untuk menghilangkan "momok Matematika menyeramkan, dan guru matematika adalah guru killer". Guru dan siswa 
hendaknya tetap bersinergi sehingga terjalin hubungan yang sehat dan baik. Momok matematika adalah menyeramkan akan kita kikis, mari kita bawa para siswa gemar matematika.

\section{DAFTAR PUSTAKA}

Defantri. (n.d.). Pembelajaran Matematika Yang Menyenangkan. Retrieved from https://www.defantri.com/2013/03/pembelajar an-matematika-yang.html

Ovinka, G. M. P. \& V. T. (2019). Matematika Dianggap "Momok" bagi sebagian Siswa. Kompasiana. Jakarta. Retrieved from https://www.kompasiana.com/vinesyatalia/5d4 d0ad80d82302ae57592e2/matematikadianggap-momok-bagi-sebagian-siswa

Rizal, J. G. (2020). Pandemi Covid-19, Apa Saja Dampak pada Sektor Ketenagakerjaan Indonesia? Kompas. Jakarta. Retrieved from https://www.kompas.com/tren/read/2020/08/ 11/102500165/pandemi-covid-19-apa-sajadampak-pada-sektor-ketenagakerjaan-indonesia?page=all. 
$\mathbf{5 8}$ | Yang Terdepan dalam Menghadapi Pembelajaran Daring 


\section{IMPLEMENTASI PERMAINAN TRADISIONAL DALAM MENINGKATKAN PHYSICAL LITERACY ANAK DI MASA PANDEMI}

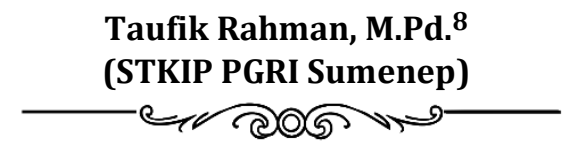

"Permainan tradisional yang dilakukan oleh anak-anak dapat meningkatkan kamampuan physical literacy karena permainan tradisional dapat menstimulus anak untuk aktif melakukan aktivitas gerak"

Dendidikan jasmani olahraga dan kesehatan diajarkan di sekolah baik di tingkat sekolah dasar dan sekolah menengah yang melibatkan aktivitas fisik. Aktivitas fisik yang diajarkan melalui materi atletik, aquatic, aktivitas ritmik, permainan bola besar, permainan bola kecil, permainan kecil dan permainan

\footnotetext{
8 Penulis lahir di Sumenep, 13 Januari 1987. Penulis merupakan dosen program studi Pendidikan Jasmani Kesehatan dan Rekreasi di STKIP PGRI Sumenep sejak tahun 2012. Penulis menyelesaikan gelar Sarjana Pendidikan pada program studi Pendidikan Jasmani Kesehatan dan Rekreasi tahun 2005 di Universitas Negeri Surabaya, sedangkan gelar Magister Pendidikan ditempuh di Universitas Negeri Surabaya tahun 2011 pada program studi Pendidikan Olahraga.
} 
tradisional. Pembelajaran pendidikan jasmani olahraga dan kesehatan di sekolah bertujuan untuk meningkatkan pemahaman anak terhadap physical literacy. Physical Literacy merupakan pondasi dalam pembentukan perilaku, kesadaran, pemahaman tentang pola hidup aktif, kesenangan dalam melakukan aktivitas, kemampuan untuk mengidentifikasi, memahami, menginterpretasikan, merespon secara efektif dalam pemanfaatan kemampuan gerak tubuh dalam konteks yang luas dan bervariasi (Tremblay M., 2010). Sedangkan menurut IPLA (International Physical Literacy Association) "Physical Literacy is the motivation, confidence, Physical competence, knowledge, understanding, to value and take responsibility for engagement in physical activities for live". Dari definisi di atas dapat disimpulkan bahwa elemen dasar dalam physical literacy meliputi motivasi, kepercayaan diri, kompetensi fisik, pengetahuan dan pemahaman, keterlibatan anak dalam aktivitas fisik.

Motivasi dan kepercayaan diri merupakan komponen utama dalam melakukan aktivitas fisik, oleh karena itu faktor-faktor yang mendorong meningkatnya motivasi dan kepercayaan diri anak perlu dioptimalkan. Salah satu cara untuk meningkatkan motivasi dan kepercayaan diri anak agar mereka aktif dalam melakukan aktivitas fisik yaitu dengan memberikan tugas gerak yang tidak terlalu sulit dilakukan, artinya guru memberikan tugas gerak dengan tingkat kesulitan dari mudah ke yang sulit. Harapannya anak dapat berhasil melakukan tugas gerak yang ditugaskan oleh guru sehingga dapat meningkatkan motivasi dan kepercayaan diri untuk melakukan tugas gerak berikutnya. Gerakan-gerakan yang mudah dilakukan juga berpengaruh terhadap tingkat pengetahuan dan pemahaman anak akan tugas gerak yang diberikan, sehingga anak bisa memproduksi gerak yang 
ditugaskan. Keterlibatan anak dalam aktivitas melalui tugas gerak yang diberikan guru dapat meningkatkan kompetensi fisik (peningkatan keterampilan dan pola gerakan) anak. Tujuan dari pemahaman terhadap physical literacy ini adalah agar anak terlibat dalam aktivitas fisik dalam kehidupan sehari-hari secara teratur sehingga aktivitas fisik menjadi kebutuhan dan gaya hidup anak.

Seorang anak akan memiliki kemampuan physical literacy ketika melakukan pendidikan secara disengaja melalui pendidikan jasmani olahraga dan kesehatan di sekolah. Pembelajaran pendidikan jasmani olahraga dan kesehatan yang berkualitas di sekolah sangat membantu anak dalam meningkatkan pemahaman terhadap pentingnya physical literacy. Pembelajaran yang dilakukan oleh guru melalui aktivitas fisik seperti olahraga dan permainan tradisional merupakan cara tepat untuk meningkatkan kompetensi fisik, kesehatan, kebugaran, tanggung jawab diri, dan kegemaran aktivitas fisik bagi semua anak sehingga mereka selalu butuh untuk aktif secara fisik seumur hidup.

Sejak mewabahnya virus covid-19 pada awal tahun 2020, pembelajaran pendidikan jasmani olahraga dan kesehatan dilakasanakan secara daring (dalam jaringan). Hal ini tentunya berdampak pada keleluasaan dan kreativitas guru dalam mengajarkan aktivitas fisik di sekolah, tentunya juga berdampak pada minat dan motivasi anak dalam melakukan aktivitas fisik, karena pembelajaran tidak seperti yang lazim dilaksanakan yakni bertatap muka dengan guru dan melakukan aktivitas fisik bersama-sama teman lainnya, pembelajaran dilakukan secara mandiri di rumah dengan mengikuti instruksi dari guru.

Pada tahun 2021 ini sesuai anjuran pemerintah, pembelajaran di sekolah dilaksanakan secara daring 
dan luring atau yang lebih dikenal dengan istilah blanded learning. Untuk pembelajaran secara daring anak dituntut untuk belajar mandiri di rumah, dan pembelajaran secara luring atau pertemuan tatap muka, anak secara bergantian sesuai dengan jadwal melaksanakan pembelajaran tatap muka di sekolah dengan mematuhi protokol kesehatan yaitu menjaga jarak, mencuci tangan, memakai masker, dan menghindari kerumunan.

Diberlakukannya pembelajaran blanded learning tentunya merupakan solusi dari kejenuhan anak selama hampir satu tahun melaksanakan pembelajaran secara daring. Pada pertemuan tatap muka (luring), guru bisa memantau aktivitas fisik anak melalui pembelajaran di sekolah. Walaupun dilaksanakan secara bergantian untuk menghindari kerumunan, ini terbukti efektif untuk menjaga kesehatan, kebugaran dan meningkatkan imun anak. Pada pertemuan daring, guru tetap memberikan tugas gerak untuk dilaksanakan di rumah. Dengan tugas gerak yang diberikan oleh guru baik berupa tugas keterampilan ataupun tugas gerak melalui video tutorial (Hamdan Husein Batubara, 2020) diharapkan anak di rumah tetap aktif melakukan aktivitas fisik sehingga kesehatan dan kebugaran anak tetap terjaga. Aplikasi yang biasanya digunakan oleh guru dalam memantau dan mengontrol aktivitas fisik anak di rumah yaitu whatsapp, google meet, zoom dan media sosial lainnya (Yulianto, 2020).

Waktu yang disediakan oleh sekolah pada saat pertemuan tatap muka (luring) sangat terbatas, tidak seperti waktu di masa normal pembelajaran. Durasi anak-anak belajar tatap muka di sekolah hanya sekitar 2-3 jam saja, selebihnya anak belajar secara mandiri di rumah. Dalam memanfaatkan waktu luang di rumah, kebanyakan aktivitas anak berkutat pada aktivitas 
bermain gadget dan game online. Kecanduan anak untuk bermain gadget di masa sekarang ini, juga berpengaruh terhadap kemampuan fisik motorik dan interaksi sosial anak. Anak cenderung sibuk dengan gadget dan game online nya masing-masing sehingga mereka kurang aktif bergerak dan abai terhadap lingkungan di sekitarnya.

Disamping itu, ada juga yang mengisi waktu mereka dengan bermain dengan teman sebayanya dengan aktivitas bermain sepak bola, bermain permainan tradisional seperti bentengan, dan engklek. Hal ini cukup efektif dalam menjaga kesehatan dan kebugaran selama belajar mandiri di rumah. Interaksi sosial dengan lingkungan sekitar juga berjalan dengan baik, mereka bisa berinteraksi dan berkomunikasi pada saat bermain. Selain bermain, tanpa disadari mereka juga mengembangkan aspek kognitif, afektif dan psikomotor. Dari aspek kognitif, mereka bisa memahami cara bermain dan menentukan strategi agar menang dalam permainan. Dari aspek afektif, mereka belajar saling menghargai, saling menghormati, dan bekerja sama. Sedangkan dari aspek psikomotor, mereka bisa meningkatkan kekuatan, kecepatan, keseimbangan dan lainnya. Selain meningkatkan ketiga aspek tersebut, secara tidak langsung mereka juga melakukan aktivitas yang dapat meningkatkan kemampuan physical literacy. Sesuai dengan hasil penelitian yang dilakukan oleh (Gustian, 2019) permainan tradisional yang dilakukan oleh anak-anak dapat meningkatkan kamampuan physical literacy karena permainan tradisional dapat menstimulus anak untuk aktif melakukan aktivitas gerak.

Selain itu juga, permainan tradisional yang dimainkan oleh anak-anak pada waktu luang dapat melestarikan budaya dan kearifan lokal yang pada akhir-akhir ini sudah mulai hilang dari dunia anak, 
mereka lebih tertarik untuk bermain gadget daripada bermain permainan tradisional. Dalam hal melestarikan budaya dan kearifan lokal, guru pendidikan jasmani kesehatan dan rekreasi ikut andil melalui pembelajaran di sekolah dan diharapkan dalam pembelajaran daring memberikan tugas untuk bermain permainan tradisional bersama teman sebayanya sebagai bentuk aktivitas fisik di rumah selama pandemi.

\section{DAFTAR PUSTAKA}

Gustian, U. S. (2019). Efektifitas Modifikasi Permainan Tradisional dalam Pengembangan Physical Literacy Anak Taman Kanak-Kanak. Jurnal Keolahragaan, 23-33.

Hamdan Husein Batubara, D. S. (2020). Penggunaan Video Tutorial untuk Mendukung Pembelajaran Daring di Masa Pandemi Virus Corona. Muallimuna: Jurna Madrasah Ibtidaiyah, 74-84.

Tremblay M., L. M. (2010). Physical Literacy Measurement The Missing Piece. Physical \& Health Education Journal 76 (1), 26-30.

Yulianto, D. (2020). Pengaruh Pembelajaran Daring Pengguna Platform Digital terhada Pemecahan Masalah Matematis dan Sikap Kritis Siswa di MA Daar El Qalam. Symmetry: Pasundan Journal of Research in Mathematics Learning and Education, 107-128. 


\title{
MENDEKATKAN ANAK DENGAN SASTRA MELALUI AUDIOBOOK
}

\author{
Andarini Permata Cahyaningtyas, M.Pd. ${ }^{9}$ \\ (Universitas Islam Sultan Agung)

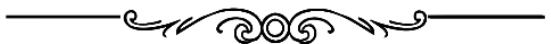

"Popularitas audiobook meningkat bersamaan dengan semakin disukainya podcast yang menghadirkan percakapan tanpa gambar"

$\mathrm{S}_{\mathrm{H}}^{\mathrm{e}}$ etahun lebih anak-anak tak lagi dapat menikmati hari-harinya di luar rumah, bermain bersama temanteman, serta belajar bersama guru di sekolah. Pandemi telah merenggut hak dan kebebasan anak untuk mengeksplorasi diri dan lingkungannya. Hal ini menjadikan anak lebih banyak menghabiskan waktu untuk menatap layar gawai ponselnya masing-masing (Laveda, 2020). Tentunya hal ini akan membawa pengaruh positif dan negatif bagi anak. Di satu sisi,

\footnotetext{
${ }^{9}$ Penulis adalah lulusan S1 Pendidikan Guru Sekolah Dasar dan S2 Pendidikan Dasar Konsentrasi Bahasa Indonesia dari Universitas Negeri Yogyakarta. Lahir di Banjarnegara, dan sekarang aktif mengajar di Prodi Pendidikan Guru Sekolah Dasar, Fakultas Keguruan dan Ilmu Pendidikan, Universitas Islam Sultan Agung. Penulis aktif menjadi pengelola Jurnal Ilmiah Pendidikan Dasar sejak tahun 2018. Di tahun 2019, penulis menjadi salah satu peserta Program Peningkatan Kemampuan Berbahasa Inggris (PKBI) yang diselenggarakan oleh Kemenristek Dikti di ITB selama bulan Agustus-November.
} 
anak-anak menjadi semakin jauh dari istilah gaptek atau gagap teknologi sejak kecil. Berbagai aplikasi dapat mereka operasikan untuk mencari apa yang ingin diketahui, atau hanya sekedar untuk menghibur diri. Namun di sisi lain, anak-anak yang tidak dibantu oleh orang tuanya untuk mengontrol aktivitas penggunaan gawainya akan menjadi kecanduan dan sulit untuk melepaskan diri dari benda kecil serba bisa tersebut.

Terlepas dari dampak negatif yang ditimbulkan oleh gawai itu sendiri, kegiatan belajar dari rumah yang membatasi anak-anak untuk melakukan aktivitas di luar rumah juga dapat menimbulkan berbagai macam akibat, seperti munculnya kecemasan dalam diri anak. Kecemasan tersebut muncul karena anak-anak merasa sulit dalam memahami materi yang diberikan oleh guru, kesulitan untuk mengerjakan dan mengumpulkan tugas sesuai dengan deadline yang telah ditentukan, keterbatasan koneksi internet dari tempat tinggal mereka, munculnya kendala-kendala teknis selama proses pembelajaran, serta perasaan khawatir untuk menghadapi kegiatan pembelajaran selanjutnya (Oktawirawan, 2020). Anak-anak, khususnya usia sekolah dasar, juga akan merasakan jenuh dan bosan dikarenakan pemberian tugas rutin oleh gurunya (Sari et al., 2021).

Kecemasan dan kebosanan yang terus menerus tentunya akan menimbulkan dampak negatif yang semakin besar. Oleh karena itu, perlu ada kegiatan lain sebagai pengalih perhatian anak dari gawai dan tugastugas sekolah. Salah satu kegiatan bermanfaat yang dapat dilakukan oleh anak-anak di rumah adalah dengan membaca karya sastra. Ada beberapa genre karya sastra yang dapat dinikmati anak-anak di rumah, antara lain buku bergambar, puisi, dongeng tradisional dan modern, fiksi realistis, fiksi historis, buku informasi, 
serta biografi (Darigan et al., 2002). Genre-genre seperti dongeng dan fiksi modern banyak dituangkan dalam bentuk komik, novel, atau pun cerita bersambung, yang sebenarnya mudah ditemukan di toko buku terdekat. Hanya saja, memang tidak semua orang tua gemar memperkenalkan sastra kepada anak sejak kecil. Selain itu, orang tua tidak akan dapat membuat anak-anaknya suka membaca apabila mereka sendiri menjadi sosok figur orang tua yang tidak suka membaca. Sebagai contoh, apabila sehari-harinya anak lebih sering melihat orang tuanya memegang gawai, maka anak-anak pun akan meniru hingga pada akhirnya dapat merusak pola pikir anak dan membuat mereka malas membaca buku (Ihsan, 2020).

Padahal, di zaman serba canggih sekarang ini, banyak yang mulai mendigitalisasi buku atau yang biasa kita kenal dengan e-book atau buku elektronik. Pertanyaannya yang muncul kemudian adalah apakah buku cetak memberikan pengaruh yang sama dengan buku elektronik? Jawabannya adalah tidak. Berdasarkan hasil penelitian, buku cetak masih menjadi pilihan terbaik bagi kemampuan optik, kognitif, serta metagkognitif yang dibutuhkan otak anak saat membaca (Tanner, 2014). Oleh karena itu, membelikan buku cetak bagi anak seharusnya masih menjadi opsi utama orang tuanya saat ingin memperkenalkan sastra pada anak. Membaca buku elektronik juga sama saja tidak menjauhkan anak dari layar, karena memang buku elektronik ini tersedia dalam bentuk file yang disimpan pada gawai, laptop, atau PC.

Sayangnya, pandemi mengakibatkan kondisi perekonomian keluarga menengah ke bawah di Indonesia menjadi terganggu. Usaha yang tidak berjalan semestinya menyebabkan banyak perusahaan yang harus mengurangi jumlah karyawannya, hingga 
menutup cabang-cabang yang mereka miliki. Himbauan untuk membatasi mobilitas di luar rumah juga menyebabkan para pengemudi ojek daring kehilangan pelanggan hingga tak lagi mampu mendapatkan penghasilan yang cukup. Hal ini membuat banyak keluarga yang mengencangkan ikat pinggang agar mampu bertahan hidup, dan tak lagi dapat menyediakan fasilitas belajar dan hiburan bagi anak-anaknya. Untuk itulah, orang tua perlu mencarikan alternatif bagi anak agar dapat terus mengenal sastra di saat mereka tak lagi mampu membelikan buku-buku untuk anak-anaknya atau tidak beroperasinya perpustakaan yang koleksi buku-bukunya dapat mereka baca di sela kegiatan belajar daring.

Salah satu alternatif yang dapat dipilih oleh orang tua untuk mengatasi kebosanan anak selama di rumah adalah audiobook. Pada dasarnya, audiobook adalah suatu bentuk rekaman suara yang memuat isi buku jenis apapun (seperti buku teks ilmiah, buku fiksi, atau jenis lainnya), yang dibacakan oleh si penulis, narator profesional, atau suara sintesis (Anwas, 2014; Have \& Pedersen, 2013). Pengembangan audiobook sebenarnya sudah dilakukan beberapa saat setelah Thomas Alpha Edison menemukan fonograf dan bermimpi bahwa suatu hari nanti akan ada teknologi yang mampu merekam seluruh isi buku (Thorp, 2020). Seiring berjalannya waktu dan berkembangnya teknologi, kini kita dapat menemukan ratusan ribu audiobook dari seluruh penjuru dunia. Popularitas audiobook meningkat bersamaan dengan semakin disukainya podcast yang menghadirkan percakapan tanpa gambar sehingga penggunaan dan penjualan audiobook meningkat sejak satu dekade terakhir (Have \& Pedersen, 2020; Thorp, 2020). 
Kesukaan masyarakat masa kini dengan audiobook tentunya bukan tanpa alasan. Audiobook memiliki beberapa keunggulan, antara lain bahwa audiobook pada dasarnya memanfaatkan kemampuan manusia yang telah mahir berkomunikasi secara lisan sejak sepuluh ribu tahun lalu. Sebagai pendengar, manusia mampu memperoleh banyak informasi dari perubahan nada suara atau intonasi (Heid, 2018). Sebagai contoh, ketika anak-anak membaca buku cerita, mereka harus menerka-nerka seperti apa intonasi yang sesuai untuk sebuah narasi atau dialog. Jika anak-anak masih kurang memahami tanda baca, maka mereka juga akan mengalami kesulitan untuk mengiterpretasikan nada suara yang mewakili kalimat dengan tanda baca tersebut. Seperti saat ada dialog yang diakhiri dengan tanda seru, maka berarti dialog tersebut menunjukkan intonasi dengan tekanan tinggi (contoh: marah, kagum, kaget, dsb); atau misal koma yang menandakan seharusnya klausa dibaca dengan adanya jeda sebelum melanjutkan ke klausa berikutnya.

Selain itu, ketersajiannya dalam bentuk micro-file (biasanya dalam format MP3) menjadi kunci utama fleksibilitas dan mobilitas yang dimiliki oleh audiobook (Have \& Pedersen, 2013). Hal ini menjadikan audiobook dapat diputar melalui banyak variasi media elektronik, seperti ponsel, MP3 player, wireless speaker, laptop atau PC, smart tv, dll. Selain itu, ukuran file yang tidak terlalu besar memungkinkan kita memindahkannya secara lebih mudah dari satu perangkat ke perangkat lainnya melalui bluetooth atau sarana lainnya. Oleh karena itu, kita akan dengan mudah memutar audiobook kapan pun dan dimana pun tanpa anak harus menghadap layar terus menerus.

Penerapan audiobook dalam kehidupan anak juga memberikan berbagai macam keuntungan, baik bagi 
yang bersangkutan, guru, maupun orang tua (Serafini, 2004), yakni di antaranya:

1. Mendongkrak kemampuan guru dan orang tua dalam membacakan cerita bagi anak-anak;

2. Memperkenalkan kosakata baru bagi anak, yang menjadi salah satu kunci kesuksesan dalam membaca;

3. Menjadi sebuah demonstrasi bagaimana membaca secara fasih;

4. Memungkinkan anak-anak untuk mengakses buku yang tidak bisa mereka baca;

5. Membuka kesempatan bagi anak untuk mendiskusikan cerita sebagai salah satu upaya untuk memahami isinya;

6. Membantu anak-anak yang kesulitan membaca untuk lebih berfokus pada muatan dan makna yang terkandung;

7. Mengundang anak untuk memasuki keajaiban dunia sastra; serta

8. Meningkatkan kecintaan anak terhadap sastra dan kegiatan membaca.

Berdasarkan penjelasan di atas, kita bisa mengetahui bahwa audiobook dapat menjadi sarana bagi anak untuk dekat dengan sastra, atau bahkan mencintai sastra. Sastra menjadi sebuah pelarian terbaik bagi anak yang sedang mengalami kebosanan dan kejenuhan akibat belajar daring dibandingkan dengan permainanpermainan dalam gawai mereka. Sastra yang merupakan sebuah karya yang disampaikan melalui bahasa, sebenarnya "lebih dari sekedar bahasa". Bahasa dalam teks kesastraan "hanya" menjadi sarana semata, karena yang terpenting adalah muatan nilai dan moral di dalamnya (Nurgiyantoro, 2010). Muatan nilai dan 
moral inilah yang akan menjadi sumber pembelajaran dan penanaman karakter dalam diri anak. Melalui sastra, anak-anak dapat belajar hal yang baik dan buruk, serta mana yang patut untuk ditiru dan mana yang tidak. Oleh karena itu, pendampingan orang tua sangatlah penting untuk dapat memaksimalkan internalisasi nilai-nilai karakter dan moral dalam diri anak.

Seperti yang telah dijelaskan di atas, audiobook akan sangat bermanfaat bagi anak yang masih mengalami kesulitan dalam membaca (seperti banyak terjadi di kalangan anak-anak SD kelas 1), serta anak-anak yang tidak terlalu menyukai kegiatan membaca. Oleh karena itu, selama masa pandemi Covid-19 ini, orang tua dapat mulai memperkenalkan audiobook kepada anak-anak agar mereka mengenal cara lain dalam "membaca". Banyak sekali situs-situs yang menyediakan audiobook bermuatan sastra anak secara gratis, salah satunya adalah Audible yang menyediakan lebih dari 500 file dalam bahasa Inggris, Spanyol, Perancis, Jerman, Italia, dan Jepang; Librophile yang menyediakan koleksi fiksi, dongeng, dan cerita rakyat; serta Bookbox yang berisi rekaman cerita-cerita pendek untuk anak ("5 Situs Pilihan Berburu Audiobook Gratisan," 2013; Pratama, 2020).

Sayangnya, belum ada situs yang secara khusus menyajikan audiobook berisi cerita anak dalam bahasa Indonesia. Meskipun demikian, ada beberapa akun Youtube yang menyediakan audiobook yang berisi dongeng anak, di mana salah satunya adalah channel milik Ichannisart Project (Ichannisart Project, n.d.). Di situ kita bisa menemukan dongeng-dongeng seperti Kisah Peter Kelinci, Monyet Mike, Kue Kismis Bu Topple, dll. Beberapa channel lain juga ada yang menyediakan konten audiobook meski tidak spesifik hanya berisi 
audiobook saja, tapi ada pula yang menggabungkan dengan konten video dongeng. Dari keterbatasan inilah, para akademisi dan praktisi sastra anak Indonesia dapat mulai menggiatkan produksi audiobook gratis berbahasa Indonesia agar anak-anak Indonesia pun dapat menikmati karya-karya orisinil dalam negeri dalam bentuk audio dan akan menjadi generasi yang lebih mencintai sastra ketimbang game online di masa yang akan datang.

\section{DAFTAR PUSTAKA}

5 Situs Pilihan Berburu Audiobook Gratisan. (2013). Detik News. https://inet.detik.com/consumer/d2205060/5-situs-pilihan-berburu-audiobookgratisan

Anwas, 0. M. (2014). Audiobook: Media pembelajaran masyarakat modern. Jurnal Teknodik, 18(1), 5462.

Darigan, D. ., Tunnel, M. ., \& Jacobs, J. . (2002). Children's literature: Engaging teachers and children in good books. Pearson Education, Inc.

Have, I., \& Pedersen, B. S. (2013). Sonic mediatization of the book: Affordance of the audiobook. Journal of Mediatization and Cultural Change2, 29(54), 123140.

https://doi.org/10.7146/mediekultur.v29i54.728 4

Have, I., \& Pedersen, B. S. (2020). The audiobook circuit in digital publishing: Voicing the silent revolution. New Media and Society, 22(3), 409-428. https://doi.org/10.1177/1461444819863407

Heid, M. (2018, September 6). Are Audiobooks As Good For You As Reading? Here's What Experts Say. 
Time. https://time.com/5388681/audiobooksreading-books/

Ichannisart Project. (n.d.). Videos [Youtube Channel]. Youtube.

https://www.youtube.com/channel/UCJkRfrP0C Ubr6hmuAzZikrQ/videos

Ihsan, D. (2020, September 8). Orangtua Jadi Contoh Anak agar Gemar Baca Buku. Kompas. https://www.kompas.com/edu/read/2020/09/0 8/202339271/orangtua-jadi-contoh-anak-agargemar-baca-buku

Laveda, M. (2020, November 10). Pandemi Membuat Anak Muda Lebih Banyak Menatap Layar Ponsel. Republika.

https://www.republika.co.id/berita/qjl2bq423/p andemi-membuat-anak-muda-lebih-banyakmenatap-layar-ponsel

Nurgiyantoro, B. (2010). Sastra anak dan pembentukan karakter. Cakrawala Pendidikan, 29(Edisi Khusus Dies Natalis UNY), 25-40.

Oktawirawan, D. H. (2020). Faktor pemicu kecemasan siswa dalam melakukan pembelajaran daring di masa pandemi Covid-19. Jurnal Ilmiah Universitas Batanghari Jambi, 20(2), 541. https://doi.org/10.33087/jiubj.v20i2.932

Pratama, K. R. (2020). Ratusan Cerita Anak dalam Bentuk Audio Tersedia Gratis di Audible. Kompas. https://tekno.kompas.com/read/2020/03/26/0 7020067/ratusan-cerita-anak-dalam-bentukaudio-tersedia-gratis-di-audible-

Sari, P. R., Tusyantari, N. B., \& Suswandari, M. (2021). Dampak pembelajaran daring bagi siswa sekolah 
dasar selama COVID-19. Prima Magistra: Jurnal Ilmiah Kependidikan, 2(1), 9-15.

Serafini, F. (2004). Audiobooks \& Literacy: An Educator's Guide to Utilizing Audiobooks in the Classroom. Listening Library.

Tanner, M. J. (2014). Digital vs. print: Reading comprehension and the future of the book. School of Information Student Research Journal, 4(2). https://doi.org/10.31979/2575-2499.040206

Thorp, C. (2020). Audiobooks: The rise and rise of the books you don't read. BBC. https://www.bbc.com/culture/article/20200104 -audiobooks-the-rise-and-rise-of-the-books-youdont-read 


\title{
MENGAJARKAN BERSABAR MENJAGA KESEHATAN PADA ANAK DI MASA PANDEMI
}

\author{
Siti Khoirun Nisak, S.Pd.I., M.Pd. ${ }^{10}$ \\ (UIN Sayyid Ali Rahmatullah Tulungagung)

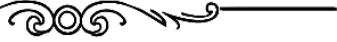

"Pentingnya peran orang terdekat anak untuk mengajak atau mengajarkan pada anak untuk menerapkan protokol kesehatan"

Sejak tahun 2020 sampai bulan Mei 2021 ini $S$ merupakan tahun dimana seseorang benar-benar diuji secara lahir dan batin terhadap kasus virus corona. Tidak hanya Indonesia, bahkan seluruh dunia merasakan dampak virus ini. Banyak orang berharap virus ini segera berakhir dan tidak ada lagi korban dari virus ini. Kasus Wuhan sangat mengerikan di telinga. Baru-baru ini ada kasus corona dengan varian baru di India yang mana orang menyebutnya tsunami covid-19. Hal itu dapat menjadi pelajaran bagi semua bahwa tidak boleh menganggap sepele tentang virus corona. Bukan berarti kita ketakutan, namun bertindak hati-hati, tidak

10 Penulis lahir di Tulungagung, 22 September 1993, penulis merupakan Dosen IAIN Tulungagung dalam bidang ilmu Pendidikan Agama Islam. 
ceroboh, mematuhi saran pemerintah untuk selalu menjaga protokol kesehatan.

Kondisi anak ketika terdapat pandemi ini di beberapa situasi akan lebih manja, ada juga anak yang lebih kreatif, tergantung pada kondisi anak tersebut. Namun ketika berpergian keluar, anak anak terkadang abai untuk memakai masker atau faceshield. Ketika penulis sepulang dari bekerja, mengamati bahwa banyak anak-anak yang masih bergerombol dengan teman-temannya tanpa masker, padahal di masa pandemi saat ini. Mereka mengobrol santai tanpa masker dan tanpa menjaga jarak dengan temantemannya sambil memancing, bermusik, dan bermain lainnya. Padahal pemakaian masker, cuci tangan, menjaga jarak sangat penting untuk diterapkan di masa pandemi.

Terbesit di benak penulis, dalam hal ini pentingnya peran orang terdekat anak untuk mengajak atau mengajarkan pada anak untuk menerapkan protokol kesehatan tersebut. Orang terdekat anak termasuk teman-teman atau kawan-kawan dari anak sangat berperan penting untuk mempengaruhi anak dalam mengajak mencegah corona. Memang bagi sebagian orang atau anak bahwa memakai masker itu bikin sesak atau tidak nyaman, karena kebiasaan sebelumnya tanpa masker dalam keseharian. Namun kita sebagai orang terdekat anak bisa memetik dari kejadian corona ini, tentang apa yang harus diajarkan pada anak, yaitu mengajarkan kesabaran.

Kata sabar mudah diungkapkan tapi terkadang sulit dilaksanakan atau dilakukan. Dari situasi pandemi saat ini kita orangtua malah mudah mengajarkan arti kesabaran pada anak. Pertama, tentang mencuci tangan atau memakai handsanitizer; Kita bisa memberitahukan pada anak bahwa kita masih diberi air yang murah tidak 
kesulitan, maka mari membiasakan mencuci tangan atau memakai handsanitizer. Ketika anak malas, maka kita mengajak anak untuk bersabar belajar disiplin melakukannya. Orang terdekat bisa mencontohkan dengan membawa handsanitizer atau antiseptic kemana-mana dan memakainya.

Kedua, tentang memakai masker; Ini yang banyak dijumpai di anak-anak jika memakai masker sering lepas. Orang terdekat bisa memberi pesan pada anak tentang pentingnya masker lalu mengajak bersabar memakai masker demi kesehatan bersama. Jika hal itu diabaikan anak, maka orangtua bisa melakukan langkah lain dengan cara melarang anak berpergian atau bermain dengan teman lainnya. Hal ini secara tidak langsung mengajarkan anak bersabar menghadapi situasi yang kurang menyenangkan ini.

Ketiga, menjaga jarak; Jika orangtua mau berpergian keluar dan anak ingin ikut, namun anak sering abai memakai masker, maka orangtua tidak mengijinkan anaknya keluar bersamanya. Dalam melarang ini orangtua tetap disarankan menyampaikan dengan halus kepada sang anak. Halus tapi tegas. Secara tidak langsung anak bersabar untuk memakai masker, sehingga bisa diijinkan untuk berpergian dengan orangtuanya. Ketika sampai di tempat kerumunan orang, orangtua memberi contoh pada anak untuk sebisa mungkin menghindari kerumunan tersebut jika dapat dihindari. Jika hal itu tidak memungkinkan maka anak memakai masker tebal dan jika perlu memakai sarung tangan supaya jika tidak sengaja menyentuh apapun bisa terhindar dari virus.

Sebenarnya protokol kesehatan yang dihimbaukan berpesan mengajak bersabar untuk disiplin menjaga kesehatan. Tiga langkah yang disebutkan merupakan ajakan secara praktek langsung pada anak. Ada ajakan 
berupa renungan pada anak tentang makna sabar. Mari kita ajak anak melihat kondisi Wuhan dan India. Kita mengajak anak untuk tidak ketakutan pada corona, namun mengajak hati-hati. Kondisi bisa melihat suasana di luar sana melalui beberapa media sosial bersama anak, bisa kita manfaatkan untuk mengobrol bersama sang anak.

Misal kita berkata pada anak, " Adek tetap ingin sehat kan, tetap ingin bermain bersama teman-teman kan, maka memakai masker, cuci tangan ya, jangan sering bermain di luar. Karena jika adek dan temanteman menjaga kesehatan, maka nanti bisa bermain lagi dengan lebih menyenangkan. Lihat di Wuhan dan India, mereka tidak bisa bermain bersama teman-temannya lagi karena banyak yang sakit. Adek terus berdoa ya semoga pandemi segera berakhir. Allah pasti mendengar doa kita dan mengabulkannya. Namun kenapa sekarang masih ada, maka itu karena kita masih kurang disiplin untuk memakai masker dan sebagainya. Maka mari kita bersabar untuk disiplin menjaga kesehatan. Allah Maha melihat jika hamba-Nya bersungguh-sungguh atau tidak". Cepat atau lambat jika orang tua berpesan ini dan memberi contoh praktek seperti yang dikatakan, maka anak akan mengikuti. Karena sifat anak meniru apa yang ada di dekatnya.

Selain kejadian corona, kejadian bencana banjir, gempa, tenggelamnya kapal selam Naggala 402 di negara tercinta bisa kita renungkan bersama anak. Bisa anak sendiri yang mengutarakan pendapatnya lalu kita dapat memberi pelajaran tentang sabar. Dari kejadian bencana yang terjadi mari mengajak anak merenung betapa sedihnya keluarga yang ditinggalkan ayahnya, suaminya, atau anaknya dari yang terkena bencana atau kecelakaan. Kita sampaikan pada anak, bahwa sabar kita untuk menjaga protokol kesahatan itu ringan, lebih 
berat mereka yang terkena bencana atau kecelakaan. Mereka seperti kehilangan harapan mendadak dan tidak tahu langkah apa yang dilakukan. Lalu kita kembalikan pada menjaga bab atau perihal menjaga protokol kesehatan, supaya semua sehat.

Kita sampaikan pada anak tentang jika kita satu orang mematuhi protokol kesehatan dan satu orang lain lagi mematuhi maka akan memutus rantai covid secara tidak langsung, maka jangan menyepelekan satu orang. Segala aktivitas di masa pandemi ini banyak yang dibatasi karena untuk memutus rantai covid-19. Hal ini kita renungkan bersama anak supaya bersabar membatasi aktivitasnya yang berkerumun atau di luar. Aktivitas yang dibatasi, namun ide kreatif bisa dituliskan dengan cara yang tidak harus berkumpul secara langsung. Bersabar sementara menjaga protokol kesehatan dan berdoa akan segera menyudahi virus corona ini. 
80 | Yang Terdepan dalam Menghadapi Pembelajaran Daring 


\title{
MOTIVASI BELAJAR PESERTA DIDIK KELAS IX SMP NEGERI 3 WEWEWA TIMUR MENJELANG PENILAIAN AKHIR TINGKAT SATUAN PENDIDIKAN (PATSP) MASA PANDEMI COVID - 19
}

\author{
Oce Regina Talan, S.Pd.,Gr ${ }^{11}$ \\ (Universitas Nusa Cendana Kupang)

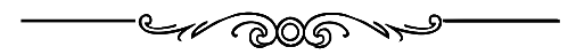

"Kurang atau bahkan tidak adanya motivasi belajar dari dalam diri peserta didik menjadi hal yang serius dalam proses pembejalaran di sekolah"

Dendidikan adalah hal yang sangat penting dalam
kehidupan setiap orang. Jika bidang pendidikan
pincang, maka pincang pulalah suatu Negara. Indonesia

11 Penulis lahir di Tetaf, 21 Oktober 1988. Penulis menyelesaikan Pendidikannya Di FKIP Bimbingan Konseling Universitas Nusa Cendana Kupang pada Januari 2013. Tahun 2013, Penulis mengikuti Program Sarjana Mendidik Di Daerah Terluar, Terdepan dan Tertinggal dan di tempatkan di Kabupaten Kutai Barat Kalimantan Timur sampai dengan tahun 2014. Tahun 2015, Penulis melanjutkan Pendidikan Profesi Guru pada Universitas Negeri Surabaya dan lulus tahun 2016 dengan mendapatkan gelar 'Gr/ Guru Profesional'. Tahun 2017 Penulis mengikuti seleksi CPNS jalur khusus Guru Garis Depan dan di tempatkan untuk mengajar di SMP Negeri 3 Wewewa Timur Kabupaten Sumba Barat Daya Propinsi Nusa Tenggara Timur Sampai Sekarang. 
merupakan salah satu Negara yang sangat memberi perhatian pada bidang pendidikan. Bahkan pendidikanpun sudah diatur dalam Undang - Undang bahwa "Setiap orang berhak memperoleh pendidikan". Pelaksanaan pendidikan di Indonesia sangatlah bervariasi, ada pendidikan Formal, Pendidikan Non Formal dan adapula pendidikan informal. Hal ini dimaksudkan agar setiap orang dapat mengeyam pendidikan.

Sistem pendidikan di Indonesia yakni sistem pendidikan nasional terdiri dari tiga jenjang yaitu pendidikan dasar, pendidikan menengah dan pendidikan tinggi. Wajib belajar di Indonesia terdiri dari 12 tahun yakni 6 tahun pendidikan dasar dan 6 tahun pendidikan menengah. Sistem pendidikan nasional nasional berupaya untuk memberikan pengetahuan kepada peserta didik baik secara akademis, keterampilan serta mengembangkan sikap positif yang dikelola atau diatur dalam kurikulum.

Kurikulum merupakan perangkat mata pelajaran dan program pendidikan yang diberikan oleh suatu lembaga penyelenggara pendidikan yang berisi rancangan pelajaran yang akan diberikan kepada peserta didik dalam suatu periode jenjang pendidikan. Kurikulum di Indonesia terus berkembang seiring berkembangnya waktu disesuaikan dengan kebutuhan peserta didik dan perkembangan ilmu pengetahuan dan teknologi, tanpa menghilangkan atau meniadakan konsep dasar suatu mata pelajaran dalam setiap jenjang pendidikan. Perubahan dan atau pengembangan kurikulum ini pun didasarkan pada kesadaran bahwa kehidupan bermasyarakat, berbangsa dan bernegara yang terus berkebambang seiring perkembangan ilmu pengetahuan dan teknologi. 
Peserta didik sebagai pelaku pendidikan dalam semua jenjang dituntut untuk mampu mencapai kriteria ketuntasan belajar mimimum dalam setiap mata pelajaran pada jenjangnya. Kriteria kentuntasan belajar mimimun tersebut tidak terlepas dari kurikulum yang sedang berjalan pada satuan pendidikan sebagai penyelenggara pendidikan. Dalam penentuan kriteria ketuntasanpun bervariasi disesuaikan dengan tingkat kesulitan setiap mata pelajaran serta tingkat pendidikan pada setiap jenjang. Semakin tinggi tingkat pendidikan atau kelas pada suatu jenjang pendidkan maka semakin tinggi kriteria ketuntasan belajar mimimum yang harus dicapai oleh peserta didik.

Nadiem Anwar Makarim, B.A.,M.B.A adalah seorang pengusaha Indonesia yang resmi menjabat sebagai Menteri Pendidikan dan Kebudayaan Indonesia pada kabinet Indonesia maju, masa pemerintahan presiden Ir. Joko Widodo - K.H Ma'ruf Amin yang dilantik pada 23 Oktober 2019. Banyak hal yang menjadi terobosan baru dari menteri Nadiem terkait dengan pendidikan di Indonesia pada awal menjabat sebagai menteri pendidikan. 4 hal pokok yang menjadi kebijakan dalam bidang pendidikan nasional melalui program "Merdeka Belajar" adalah gebrakan yang tentunya sangat berperan penting dalam bidang pendidikan.

Program "Merdeka belajar" ini meliputi Ujian Sekolah Berstandar Nasional (USBN), Ujian Nasional (UN), Rencana pelaksanaan pembelajaran (RPP) dan peraturan penerimaan peserta didik baru (PPDB) berbasis Zonasi. Menurut Nadiem, Empat hal tersebut merupakan arah pembelajaran kedepan yang berfokus pada peningkatan kualitas sumber daya manusia Indonesia. Tahun 2020 merupakan tahun pelaksananan 
UN terakhir sesuai dengan kebijakan tersebut. Artinya bahwa setelah itu tidak akan ada ujian nasional yang sangat menegangkan bagi peserta didik pada tingkat akhir disetiap jenjang pendidikan, baik itu pendidikan dasar maupun pendidikan menengah. Ujian Sekolah berstandar nasional untuk peserta didik pada tingkat akhir satuan pendidikan pada setiap jenjang yang semula diselenggarakan oleh pemerintah pusat dialihkan untuk diselenggarakan di sekolah masing masing.

Tahun 2020, virus Corona muncul dan menjadi wabah dunia yang sangat meresahkan semua orang. Tingkat penularan dan angka kematian karena wabah virus corona yang semakin tinggi dari waktu ke waktu menyebabkan lumpuhnya kehidupan di berbagai Negara dalam segala bidang. Indonesiapun tidak luput dari wabah ini. Aktifitas dalam semua bidang kehidupan menjadi sangat terhambat akibat penyebaran virus ini. Pelaksanaan pembelajaran dalam bidang pendidikanpun menjadi terganggu.

Wabah yang semakin hari semakin merajalela di seluruh pelosok negeri dan angka kematian yang semakin melonjak menjadi perhatian besar dari para pemangku kebijakan di Indonesia. Tak terkecuali dalam bidang pendidikan. Menteri pendidikan dan kebudayaan mengambil beberapa kebijakan sebagai strategi pemutusan rantai penularan dan mengurangi angka kematian akibat Covid -19 ini. Dan pada akhirnya tahun 2020 yang sebelumnya menjadi tahun terakhir pelaksanaan USBN dengan penyelenggara pemerintah pusat dan tahun terakhir pelaksaaan Ujian Nasional menjadi tahun pertama ditiadakannya pelaksanaan Ujian nasional dan penyelenggara USBN adalah Sekolah pada tingkat satuan pendidikan masing - masing. 
Peserta didik kelas IX SMP Negeri 3 Wewewa Timur tahun pelajaran 2019/2020 yang menjadi angkatan pertama lulus tanpa ujian nasional karena wabah virus corona. Pelaksanaan USBN di sekolahpun berupa penilaian portofolio dan pemberian tugas. Sebagai angkatan pertama yang lulus tanpa ujian nasional kemudian muncullah istilah yang dibuat oleh sekelompok orang dan kemudian beredar bahwa lulusan tahun 2020 untuk semua jenjang pendidikan adalah "Angkatan Corona". Entah dari mana istilah ini, yang jelas istilah ini sempat viral di social media.

Kegiatan belajar - mengajar pada tahun pelajaran 2020/2021 di SMP Negeri 3 Wewewa Timur berlangsung dengan menggunakan sistem belajar di sekolah skala terbatas. Hal ini dikarenakan wabah virus corona kemudian menjadi pandemi yang secara terus menerus menular dan meresahkan. Belajar di sekolah skala terbatas merupakan pilihan untuk pelaksanaan kegiatan proses belajar mengajar dengan pertimbangan tidak mungkin pembelajaran daring dilaksanakan di daerah pedalaman. Tidak adanya listrik, tidak adanya jaringan internet dan bahkan tidak adanya hanphone dari peserta didik menjadi kendala untuk pembelajaran daring.

Belajar di sekolah skala terbatas pada SMP Negeri 3 Wewewa Timur Tahun pelajaran 2020/2021 ini dirancang dengan pola belajar tiga hari di sekolah dan tiga hari di rumah. Untuk belajar 3 hari di sekolah peserta didik per kelas dibagi menjadi 2 kelompok. Setiap kelompok punya waktu 3 hari belajar di sekolah dengan tiga sampai empat mata pelajaran per hari yang di alokasikan dalam waktu 30 menit per mata pelajaran. Sangat tidaklah efektif seperti sebelum pandemic covid - 19 yang membutuhkan alokasi waktu 45 menit per jam. 
Pandemi covid -19 seakan memberi ruang bagi peserta didik untuk terus menerus tinggal di rumah dan tidak betah ketika berada di sekolah. Peserta didik menjadi malas datang di sekolah dan lebih memilih untuk tetap dirumah. Orang tua yang selalu sibuk berada di kebun dan disawahpun merasa sangatlah terbantu banyak dengan tinggalnya anak - anak di rumah. Tidak sedikit peserta didik yang tinggal di rumah dengan alasan yang tidak jelas dan bahkan ketika berada di sekolah hanya untuk menghindari pekerjaan di rumah. Kurangnya waktu belajar di sekolah tidak menjadi motivasi yang bagus untuk tetap datang di sekolah sesuai jadwal belajarnya tapi kemudian hanya dijadikan sebagai formalitas saja.

Hal yang sangat mengejutkan adalah ketika adanya proses konseling dari guru BK terhadap salah satu peserta didik yang tidak masuk sekolah selama satu minggu dan guru BK melihat catatan di buku pelajaran peserta didik tersebut, tidak ada catatan materi apapun pada buku catatan peserta didik tersebut. Yang lebih parah lagi adalah adanya tulisan "Corona" lalu di artikan sebagai "Kopi, Rokok, Nasi". Kurang atau bahkan tidak adanya motivasi belajar dari dalam diri peserta didik menjadi hal yang serius dalam proses pembejalaran di sekolah.

Menjelang akhir tahun pelajaran 2020/ 2021 untuk kelas IX, Dinas Pendidikan Kabupaten Sumba Barat Daya Propinsi Nusa Tenggara Timur menyelenggarakan Penilaian Akhir Tingkat Satuan Pendidikan (PATSP) yang diselenggarakan sepenuhnya oleh sekolah masingmasing. Informasi ini kemudian disosialisasikan kepada peserta didik kelas IX. Hal yang terjadi kemudian adalah peserta didik kelas IX tidak lagi menganggap Kegiatan PATSP ini adalah hal yang serius dan butuh persiapan diri yang maksimal. Peserta didik semakin betah di 
rumah dan jarang untuk masuk sekolah. Peserta didik dengan sesuka hatinya datang sekolah. Bahkan menjelang kegiatan PATSP, tingkat kehadiran peserta didik yang seharusnya 13 atau 14 orang per kelas bias menjadi 5 atau 6 orang per kelas.

Waktu yang sangat terbatas untuk belajar di sekolah tidak menjadi motivasi bagi peserta didik untuk datang ke sekolah. Sering tidak masuk sekolah, ijin tanpa alasan yang jelas dan bahkan hanya muncul menjelang Penilaian Tengah Semester adalah kebiasaan yang susah untuk hilang. Perubahan mungkin bias saja terjadi hanya beberapa hari ketika peserta didik diberi pembinaan dan konseling, selanjutnya kembali ke kebiasanan semula.

Motivasi belajar peserta didik kelas IX menjadi sangat rendah menjelang kegiatan pelaksanaan penilaian akhir. Peserta didik menganggap kegiatan ini hanya biasa saja dan enggan untuk belajar di sekolah apalagi belajar di rumah. Tidak adalah belajar kelompok seperti angkatan tahun 90-an yang selalu belajar kelompok menjelang Ujian Akhir. Tidak ada privatprivat yang berlangsung menjelang ujian akhir. Tidak ada ketakutan dan keresahan tidak lulus, tidak ada lagi tradisi belajar subuh sambil merendam kaki dalam air di baskom untuk mengusir rasa kantuk, tidak ada lagi persaingan menjadi juara kelas dan atau mendapatkan nilai tertinggi, yang ada hanyalah persaingan untuk menunjukan siapa yang paling banyak tinggal di rumah. Pandemi Covid -19 benar - benar melumpuhkan segalanya. 
88 | Yang Terdepan dalam Menghadapi Pembelajaran Daring 


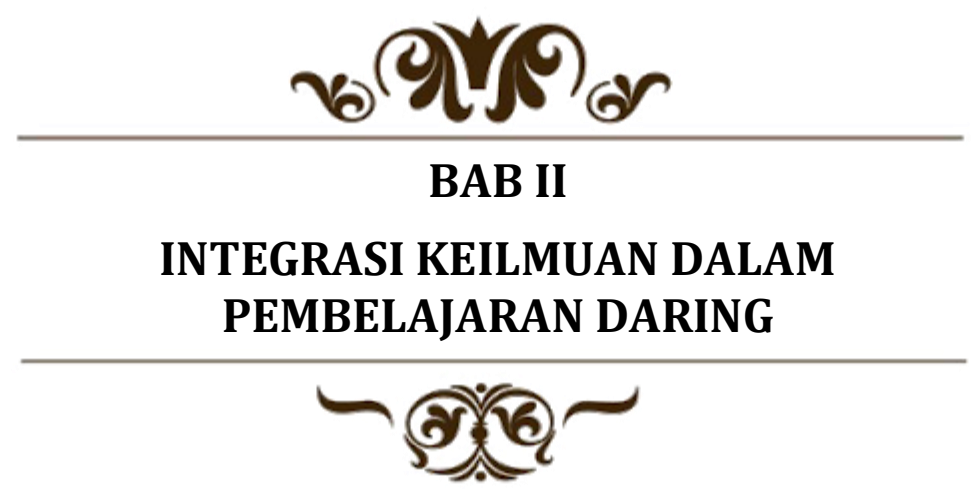


90 | Yang Terdepan dalam Menghadapi Pembelajaran Daring 


\title{
U-DICTIONARY: APLIKASI ALTERNATIF PADA PEMBELAJARAN BAHASA INGGRIS SAAT PANDEMI
}

\author{
Dr. Sholihatul Hamidah Daulay, S.Ag., M.Hum ${ }^{12}$ \\ (Universitas Islam Negeri Sumatera Utara)

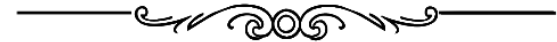

"U-Dictionary merupakan suatu aplikasi menterjemahkan kata-kata ataupun frasa singkat, aplikasi ini juga bisa menggunakan kamera untuk mencari terjemahan secara langsung dari foto, serta mampu menerjemahkan kata dalam mode offline atau tanpa adanya koneksi internet."

S aat ini kita telah memasuki era globalisasi yang perkembangan teknologi informasi. Segala bentuk informasipun dapat diperoleh dengan begitu sangat cepat dimanapun dan kapanpun tanpa adanya batasan sama sekali. Perkembangan dan kemutakhiran

12 Penulis lahir di Surabaya, 22 Juni 1975, penulis adalah Dosen UIN Sumatera Utara dalam bidang ilmu Linguistik, penulis menyelesaikan gelar Sarjana Tadris Bahasa Inggris di IAIN Sumatera Utara (1999), gelar Magister Humaniora diselesaikan di Universitas Sumatera Utara Program Studi Linguistik (2002), dan akhirnya Doktor Ilmu Linguistik diselesaikan di Universitas Sumatera Utara Fakultas Ilmu Budaya Program Studi Linguistik (2014). 
teknologi tersebut juga telah mengubah cara manusia dalam belajar dan berbahasa (Naismith dalam Rahim, 2009). Tidak dapat dipungkiri, bahasa adalah merupakan komponen yang penting dalam berkomunikasi dan berinteraksi dengan orang lain disamping komponen-komponen lain seperti nada, gerak tubuh, isyarat, dan lain sebagainya. Tanpa adanya bahasa tidak akan pernah terjadi komunikasi secara verbal ataupun non verbal, karena sangat pentingnya faktor bahasa ini sebagai alat komunikasi sehingga membuat beberapa linguis menyatakan bahwa berbahasa sama perlunya dengan bernafas.

Adapun bahasa yang sering digunakan oleh masyarakat penuturnya juga memiliki variasi tertentu. Variasi tersebut muncul bergantung pada latar belakang sosial masyarakatnya, letak geografis, pendidikan, usia, dan sebagainya. Kesemua faktor tersebut berdampak pada munculnya dialek-dialek sosial dan dialek geografi. Masyarakat bahasa selalu bersifat heterogen, dan bahasa yang digunakan selalu menunjukkan berbagai variasi internal sebagai akibat keberagaman latar belakang sosial budaya penuturnya (Wardaugh, 1986; Kaswanti Purwo, 1990:16 dalam Wijana, 1996:7). Menurut Bell (1976:191) menyatakan bahwa tidak ada satupun penutur bahasa yang memiliki satu gaya (single style speaker) karena setiap penutur bahasa pada umumnya menggunakan berbagai bahasa serta menguasai penggunaan bahasa tersebut, situasi ini juga disebut sebagai situasi bilingual (kedwibahasaan) ataupun multilingual (kemajemukan bahasa).

Kondisi di atas berdampak pula pada pembelajaran bahasa baik di dalam kelas maupun di luar kelas. Dalam proses pembelajaran bahasa khususnya bahasa Inggris, guru selalu berusaha mengkombinasikan strategi pembelajaran dengan topik ataupun materi yang ada. 
Pada materi writing atau menulis, guru akan menyuruh siswanya untuk menulis ulang materi yang baru dipelajari ataupun menulis karangan bebas dengan tata bahasa yang baik, sementara jika materi speaking atau berbicara, guru akan secara langsung melakukan tanya jawab dengan siswanya ketika melakukan zoom meeting ataupun voice note di aplikasi WhatsApp.

Sementara itu, pada materi reading atau membaca biasanya guru menyuruh muridnya untuk menjawab pertanyaan yang berhubungan dengan teks sekaligus memahami teks bacaan dengan baik. Akan tetapi dalam proses pemahaman teks bacaan ini, siswa masih mengalami kesulitan pula yakni kurang memahami makna ataupun arti dari teks tersebut, dan untuk mengatasi masalah ini maka guru memberikan solusi bagi siswanya dengan cara mengunduh aplikasi $U$ Dictionary agar memudahkan siswanya memahami teks bacaan bahasa Inggris tersebut. Penggunaan $U$ Dictionary ini adalah sebagai alternatif dari penggunaan kamus bahasa Inggris-Indonesia ataupun sebaliknya.

U-Dictionary merupakan suatu aplikasi menterjemahkan kata-kata ataupun frasa singkat, aplikasi ini juga bisa menggunakan kamera untuk mencari terjemahan secara langsung dari foto, serta mampu menerjemahkan kata dalam mode offline atau tanpa adanya koneksi internet.

\section{Penggunaan U-Dictionary pada Pembelajaran Bahasa}

Seluruh negara di dunia ini telah diserang oleh pandemi sehingga terjadi banyak perubahan pada sistem sosial masyarakat Indonesia, dan tak luput pula berdampak pada proses belajar mengajar yang biasanya dilakukan di sekolah ataupun di madrasah. Mau tidak mau, kegiatan belajar mengajar yang dilakukan melalui 
tatap muka harus diganti dengan cara Pembelajaran Jarak Jauh (PJJ) atau belajar secara daring atau online dari rumah. Dalam proses pelaksanaan pembelajaran ini, tentu saja akan menimbulkan permasalahan baru terutama pada proses pembelajaran bahasa Inggris. Sebagaimana kita ketahui bahwa bahasa Inggris adalah bahasa asing yang diajarkan di Indonesia dan juga sebagai salah satu mata kuliah wajib di Perguruan Tinggi, ataupun sebagai mata pelajaran di sekolah dasar dan menengah yang bertujuan agar ketrampilan menulis, membaca, serta berbicara menggunakan bahasa Inggris dengan baik dapat dimiliki oleh semua generasi muda Indonesia. Dengan situasi pandemi ini, para siswa merasa kesulitan dalam mempelajari bahasa Inggris disebabkan karena beberapa faktor seperti masalah kuota internet yang kurang memadai, sarana media yang kurang baik, serta kendala jaringan sinyal internet yang belum merata ke pelosok desa tempat tinggal siswa.

Pada masa pandemi sekarang, penggunaan $U$ Dictionary ini bukan hanya sekedar sebagai aplikasi kamus online/offline, akan tetapi juga sebagai aplikasi untuk penerjemah Bahasa Inggris maupun media belajar Bahasa Inggris dengan konten yang original serta praktis pula dalam penggunaannya, aplikasi ini dapat dipakai di smartphone android. Pada prakteknya, penggunaan aplikasi ini sangat berguna sekali dalam pembelajaran bahasa Inggris. Salah satunya adalah ketika guru sedang menyampaikan teks bacaan terutama pada materi translation atau terjemahan, siswa dengan mudah memasukkan kata maupun kalimat yang tidak diketahui artinya lalu tekan mencari, maka dengan cepat akan muncul makna dari kosa kata yang dimaksud tersebut. Jadi, siswa tidak perlu menghabiskan waktu yang banyak dengan membolak- 
balikkan halaman di kamus untuk mencari kosakata yang diinginkan.

Aplikasi U-Dictionary ini adalah aplikasi yang berfungsi sebagai pendukung dalam proses belajar bahasa dan sangat efektif serta efisien sehingga tingkat pemahaman bahasa Inggris siswa lebih meningkat dan tercapai lebih baik pula. Aplikasi ini juga dilengkapi oleh beberapa fitur seperti game, kuis, dan artikel bahasa Inggris untuk menambah kosakata bahasa juga memiliki tingkat keakuratan yang lebih tinggi bila dibandingkan dengan google translate, karena bisa dengan otomatis dan cepat dalam menerjemahkan kata-kata. Dilain sisi, aplikasi terjemahan bahasa ini juga telah diunduh oleh seluruh para pengguna android di dunia sebanyak 50 juta kali. Selain itu, aplikasi ini juga didukung oleh 44 bahasa asing di dunia serta memiliki kemampuan OCR yang tinggi yakni bisa menerjemahkan tulisan dan gambar melalui kamera.

\section{Kelebihan dan Kelemahan Aplikasi $U$-Dictionary}

Suatu aplikasi tentu saja memiliki kelebihan dan kekurangannya, demikian pula dengan aplikasi $U$ Dictionary ini. Aplikasi ini melengkapi fitur-fitur yang belum tersedia di aplikasi sebelumnya. Adapun kelebihan aplikasi $U$-Dictionary ini adalah:

1. Aplikasi ini menyediakan 44 bahasa asing di dunia, bisa mempelajari bahasa sesuai dengan kebutuhan.

2. Pengucapan bisa disesuaikan dengan gaya Amerika maupun British.

3. Dapat menggunakan kamera untuk menerjemahkan dari buku atau layar komputer.

4. Adanya kuis dalam bahasa asing serta permainan kata.

5. Tersedia video pembelajaran bahasa. 
6. Permainan game untuk menambah kosakata.

7. Dapat menterjemahkan kata maupun kalimat dengan tepat dan secara otomatis.

8. Dapat menterjemahkan kata dalam keadaan offline.

9. Dapat diunduh di play store secara gratis.

10.Dapat menampilkan kata dalam bahasa Inggris di lockscreen ponsel kita dengan menggunakan fitur world lock english.

11.Dapat menterjemahkan omongan orang dan katakata bahasa asing di video melalui fitur voice translate.

12.Melalui aplikasi ini bisa belajar bahasa Inggris dimanapun dan kapanpun.

Adapun kekurangan dari aplikasi U-Dictionary ini adalah:

1. Sering terjadi masalah ketika menerjemahkan dengan menggunakan kamera.

2. Belum terindex di aplikasi U-Dictionary beberapa kata yang ada di bahasa Indonesia.

3. Banyaknya pariwara atau iklan yang mengganggu dan muncul ketika menterjemahkan.

4. Besarnya ukuran aplikasi versi offlinenya dibandingkan onlinenya sehingga menyulitkan ketika harus menginstall kedua-duanya.

5. Secara default bahasa yang tersedia hanya bahasa Inggris dan bahasa Indonesia saja.

\section{Kesimpulan}

U-dictionary adalah suatu aplikasi untuk menerjemahkan bahasa asing dengan tepat dan sangat cepat, dengan melalui aplikasi ini banyak sekali bahasa 
yang dapat kita terjemahkan dengan baik dan aplikasi ini juga sangat cocok digunakan oleh guru dan siswa untuk pembelajaran bahasa saat pandemi ini. Aplikasi ini digunakan untuk memudahkan siswa dalam menerjemahkan bahasa Indonesia ke bahasa Inggris maupun sebaliknya, bisa diunduh secara gratis di Playstore maupun Appstore dengan ukuran file yang sangat minim.

Aplikasi ini juga sangat cocok bagi siswa yang sedang belajar bahasa karena penggunaannya sangat mudah dan praktis. Siswa dan guru dapat berkolaborasi dalam memahami teks bacaan dan menjawab pertanyaan soal yang ada di buku pelajaran, disisi lain aplikasi ini juga dapat mengedukasi untuk siswa-siswa yang malas membaca buku. Diharapkan aplikasi U-Dictionary ini tidak membosankan pengguna atau usernya, dengan menyajikan video seru, permainan kata, kuis dan lain sebagainya ternyata aplikasi ini terbukti lebih baik dan unggul dibandingkan aplikasi lainnya seperti google translate. Semoga U-Dictionary ini bisa dijadikan aplikasi alternatif untuk meningkatkan pembelajaran bahasa Inggris di masa pandemi saat ini.

\section{DAFTAR PUSTAKA}

Chusnu Syarifa Diah Kusuma. 2018. Integrasi Bahasa Inggris Dalam Proses Pembelajaran. Jurnal Efisiensi -- Kajian Ilmu Administrasi Edisi Agustus 2018, Vol. XV No. 2, ISSN 1412-1131, e-ISSN 2528-5750.

https://apkpure.com/id/u-dictionary-best-englishlearning-dictionary/com.youdao.hindict

https://play.google.com/store/apps/details?id=com.yo udao.hindict\&hl=in 
Maduwu, Byslina. 2016. Pentingnya Pembelajaran Bahasa Inggris di Sekolah. Jurnal Warta edisi :50. 1829-7463

Majid, A . (2012) . Mobile Learning. Bandung: Universitas Pendidikan Indonesia.

Rahimi, M. (2014). The Impact of Mobile Dictionary Use on Language Learning. Jurnal Procedia - Social and Behavioral Sciences.

Sadtono, E. (1976). An Interirn Report on the Teaching of English at the five Centres of Excellence in Indonesia. Laporan Hasil-Hasil Alumni RELC di Perguruan Tinggi. Malang: IKIP Malang. 


\title{
EFEKTIFITAS PEMBELAJARAN BAHASA SECARA DARING DI MASA PANDEMI COVID-19 PADA MAHASISWA DI KOTA PALU
}

\author{
Abdul Gafur Marzuki ${ }^{13}$ \\ (IAIN Palu)

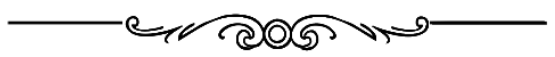

"Perkembangan teknologi dalam pembelajaran juga telah memfasilitasi dan memudahkan dosen dan mahasiswa dalam berinteraksi secara daring"

\begin{abstract}
Derkembangan teknologi khususnya dalam pembelajaran terus berkembang pesat dengan hadirnya berbagai macam pilihan aplikasi dalam pembelajaran baik secara daring maupun luring. Beberapa contoh platform yang paling banyak digunakan saat ini dalam pelaksanaan pembelajaran Bahasa secara daring adalah Canvas, Moodle, Schoology,
\end{abstract}

\footnotetext{
13Penulis lahir di Palu, 11 Juli 1983, penulis adalah dosen IAIN Palu dalam bidang Pendidikan Bahasa Inggris dan Teknologi Pembelajaran. Penulis memperoleh gelar sarjana Pendidikan Bahasa Inggris di Universitas Tadulako (2008), gelar magister Pendidikan Bahasa Inggris di Pascasarjana Universitas Tadulako (2010), Doktor Teknologi Pembelajaran di Universitas Negeri Malang (2014), dan Kursus Singkat Academic English, Academic Writing, dan Research Methodology di Universitas Leiden, Belanda (2016).
} 
Edmodo, Google Classroom, Quizziz, Kahoot, dan Duo Lingo. Sedangkan aplikasi untuk bertatap secara maya yang paling banyak digunakan adalah Zoom, Google Meet, Streamyard, dan Webex. Perkembangan teknologi dalam pembelajaran juga telah memfasilitasi dan memudahkan dosen dan mahasiswa dalam berinteraksi secara daring. Berbagai varian aplikasi dalam pembelajaran adalah aplikasi atau web yang terdiri dari sekumpulan orang yakni pengajar dan mahasiswa yang didalamnya memuat beberapa fitur yang sangat membantu dalam kelancaran proses pembelajaran daring. Aplikasiaplikasi tersebut sebagai platform pembelajaran telah dirancang untuk memaksimalkan tercapainya tujuan pembelajaran dan memfasilitasi proses pembelajaran secara daring.

Perubahan model pembelajaran dengan cara tatap muka menjadi metode daring selama pandemic Covid19 berdampak besar dalam proses pembelajaran di perguruan Tinggi khususnya pada dosen dan mahasiswa. Tidak sedikit dari mereka yang kesulitan beradaptasi dengan pembelajaran daring. Selain karena ketidaksiapan keterampilan dalam mengoperasikan aplikasi-aplikasi pembelajaran daring, koneksi internet juga menjadi masalah pokok karena tidak semua wilayah dapat terjangkau oleh koneksi internet yang stabil, bahkan dibeberapa lokasi, mahasiswa harus pergi ke tempat-tempat tertentu yang tersedia koneksi internet bahkan ada yang harus memanjat pohon untuk memperoleh koneksi. Dua hal ini selain beberapa hal lain menjadi tantangan utama dalam pembelajaran daring khususnya pembelajaran bahasa di tingkat Perguruan Tinggi selama masa pandemi Covid-19.

Tulisan ini adalah hasil penelitian dengan menggunakan metode survei. Survei ini dilakukan untuk mendapatkan data yang dibutuhkan dan juga akan 
menjadi bahan evaluasi pembelajaran secara daring. Teknik pengumpulan data menggunakan angket. Pengisian angket dilakukan secara daring menggunakan Google Form. Alasan pemilihan survei ini adalah agar penulis mendapatkan data akurat tentang keefektifan pembelajaran daring. Sampel dalam penelitian ini adalah 350 mahasiswa yang kuliah di Kota Palu, dengan margin of error kurang dari $5 \%$.

Untuk mengetahui seberapa besar efektifitas pembelajaran daring, maka penulis sebagai peneliti mengajukan beberapa pertanyaan yang terkait dengan pembelajaran daring untuk diisi oleh responden (mahasiswa) yang berasal dari beberapa Perguruan Tinggi di Kota Palu yakni Universitas Tadulako, IAIN Palu, Universitas Alkhairaat, Universitas Muhammadiyah Palu, STIE PB Palu, STIMIK Adhi Guna, dan STIMIK Bina Mulia Palu. Berikut pertanyaanpertanyaan angket yang diajukan kepada responden:

1. Bagaimana tanggapan anda mengenai pembelajaran secara daring selama masa Pandemi Covid 19?

Pertanyaan ini bertujuan untuk mengetahui tingkat kepuasan mahasiswa selama pelaksanaan pembelajaran daring. Kepuasan mahasiswa terhadap pembelajaran daring perlu diukur sebagai bahan evaluasi apakah pelaksanaan perkuliahan daring ini efektif atau justru tidak efektif. Adapun hasil survei terhadap kepuasaan mahasiswa dalam pembelajaran daring adalah terdapat $52 \%$ responden mahasiswa mengatakan tidak puas dengan pembelajaran daring dan hanya 6\% yang mengatakan sangat puas. Terdapat $8 \%$ mengatakan puas, 6\% mengatakan cukup puas, dan 28\% mengatakan kurang puas. Hal ini dapat disimpulkan bahwa pembelajaran daring tidak disukai oleh sebagian besar mahasiswa di Kota Palu dengan alasan yang beragam. 
2. Media pembelajaran apa yang paling anda senangi dalam pembelajaran daring?

Pertanyaan ini bertujuan agar penulis mengetahui aplikasi apa yang paling cocok atau disenangi untuk digunakan dalam pembelajaran daring. Adapun hasil survei terhadap aplikasi yang paling disenangi untuk digunakan dalam pembelajaran daring adalah aplikasi WhatsApp dengan persentase 66\% responden, Google Classroom dengan persentase 24\%, aplikasi Zoom dengan persentase $2 \%$, aplikasi Moodle dengan persentase $3 \%$, dan sisanya dengan persentase $5 \%$ responden memilih aplikasi Telegram, Edmodo, dan Google Meet. Adapun alasan sebagian besar responden memilih aplikasi WhatsApp untuk pembelajaran daring adalah karena aplikasi ini sangat mereka kuasai, mudah digunakan, murah, dan irit dalam penggunaan kuota dan memori. Demikian juga dengan aplikasi Google Classroom dipilih oleh responden karena mudah digunakan dan tidak membutuhkan koneksi internet yang sangat stabil. Aplikasi Zoom, Moodle, Edmodo, Telegram, dan Google Meet kurang diminati responden karena selain kurang begitu dikuasai, aplikasi tersebut juga membutuhkan koneksi internet yang sangat stabil dan memerlukan kuota internet yang besar.

3. Bagaimana penguasaan materi yang disampaikan oleh dosen melalui pembelajaran daring?

Pertanyaan ini bertujuan untuk mengetahui seberapa besar materi yang disampaikan dosen mampu dikuasai oleh mahasiswa. Pertanyaan ini akan mampu menjawab tingkat keberhasilan pembelajaran daring yang dilakukan selama masa pandemi Covid-19. Berikut adalah hasil survei terhadap tingkat penguasaan materi yang disampaikan oleh dosen kepada para mahasiswa yaitu $20 \%$ responden menjawab sangat kurang, $41 \%$ 
responden menjawab kurang, 26\% responden menjawab cukup, lalu $8 \%$ responden menjawab baik, dan sisanya $5 \%$ menjawab sangat baik. Hal ini membuktikan bahwa selama pembelajaran daring, materi yang disampaikan oleh dosen tidak dapat dikuasai dengan maksimal oleh mahasiswa. Hal ini terjadi karena banyak materi-materi Bahasa yang tidak akan maksimal untuk dikuasai jika dilaksanakan dengan pembelajaran daring (materi-materi yang sifatnya keterampilan berbahasa) selain kendalakendala teknis seperti koneksi internet, ketersediaan kuota, ketersediaan perangkat pembelajaran, dan kemampuan responden/mahasiswa dalam mengoperasikan aplikasi pembelajaran daring.

4. Menurut anda apa kekurangan dalam pembelajaran daring?

Pertanyaan ini bertujuan untuk mengetahui faktorfaktor yang menjadi penyebab tidak efektifnya pembelajaran daring. Beberapa faktor tersebut diantaranya adalah materi yang tidak cocok diajarkan secara daring, koneksi internet, ketersediaan kuota internet, ketersediaan perangkat, dan keterampilan dalam menggunakan aplikasi. Adapun hasil survei terkait kekurangan dalam proses pembelajaran secara daring yaitu terdapat $42 \%$ responden mengatakan materi sulit dipahami, $22 \%$ responden mengatakan masalah koneksi internet, $20 \%$ responden menjawab kesulitan mengoperasikan aplikasi pembelajaran daring, 12\% responden menjawab tidak memiliki kuota internet yang cukup, dan $4 \%$ responden menjawab tidak memiliki perangkat untuk digunakan seperti HP Android maupun laptop. 
5. Mana yang lebih anda sukai pembelajaran tatap muka, perpaduan tatap muka dan daring, atau pembelajaran daring?

Pertanyaan ini bertujuan untuk mengetahui keinginan responden dalam pembelajaran daring di masa pandemi Covid-19. Pilihannya adalah pembelajaran dengan total daring, perpaduan antara tatap muka dan daring, dan to tal tatap muka. Jika mayoritas responden menjawab total daring berarti pembelajaran daring ini efektif dan disukai oleh responden mahasiwa, namun sebaliknya jika mayoritas responden menjawab total tatap muka, berarti pembelajaran daring ini tidak efektif dan tidak menyenangkan. Berikut adalah hasil survei terhadap responden yakni $50 \%$ responden memilih perkuliahan tatap muka, 38\% responden memilih perpaduan tatap muka dan daring (blended), dan hanya $12 \%$ responden yang memilih daring sepenuhnya. Hasil survei ini menunjukkan bahwa mayoritas responden atau mahasiswa lebih menyukai pembelajaran tatap muka dibanding pembelajaran daring.

Dari hasil temuan tersebut, penulis dapat menyimpulkan beberapa permasalahan dalam pembelajaran daring di masa pandemi Covid-19. Pertama, materi yang disampaikan oleh dosen tidak dapat dikuasai dengan maksimal oleh mahasiswa. Hal ini terjadi karena banyak materi-materi bahasa yang tidak akan maksimal dikuasai jika dilaksanakan dengan pembelajaran daring (materi-materi yang sifatnya keterampilan berbahasa) selain kendala-kendala teknis seperti koneksi internet, ketersediaan kuota, ketersediaan perangkat pembelajaran, dan kemampuan responden/mahasiswa dalam mengoperasikan aplikasi pembelajaran daring, sehingga pihak institusi Perguruan Tinggi perlu untuk melaksanakan pelatihan 
atau Bimbingan Teknis terkait keterampilan dosen dan mahasiswa dalam menggunakan aplikasi-aplikasi pembelajaran daring. Selain itu, fasilitas koneksi internet yang stabil dan baik perlu disediakan oleh pemerintah daerah sampai pada daerah-daerah pinggiran sehingga koneksi dapat dinikmati oleh seluruh masyarakat khususnya mahasiswa yang tinggal dan berdomisili di pedesaan.

\section{DAFTAR PUSTAKA}

Adnan, M., \& Anwar, K. (2020). Online Learning amid the COVID-19 Pandemic: Students' Perspectives. Online Submission, 2(1), 45-51.

Alawamleh, M., Al-Twait, L. M., \& Al-Saht, G. R. (2020). The effect of online learning on communication between instructors and students during Covid19 pandemic. Asian Education and Development Studies.

Alek, A., Marzuki, A. G., Farkhan, M., \& Deni, R. (2020). Self-Assessment in Exploring EFL Students' Speaking Skill. Al-Ta lim Journal, 27(2), 208-214.

Baber, H. (2020). Determinants of students' perceived learning outcome and satisfaction in online learning during the pandemic of COVID19. Journal of Education and E-Learning Research, 7(3), 285-292.

Dewantara, J. A., \& Nurgiansah, T. H. (2021). Efektivitas Pembelajaran Daring di Masa Pandemi COVID 19 Bagi Mahasiswa Universitas PGRI Yogyakarta. Jurnal Basicedu, 5(1), 367-375.

Izza, A. Z., Falah, M., \& Susilawati, S. (2020). Studi Literatur: Problematika Evaluasi Pembelajaran Dalam Mencapai Tujuan Pendidikan Di Era 
Merdeka Belajar. Konferensi Ilmiah Pendidikan Universitas Pekalongan 2020, 10-15. Retrieved from

https://proceeding.unikal.ac.id/index.php/kip

Larassati, M. A. (2020). Efektifitas Media Pembelajaran Daring Edmodo dalam Perkuliahan Pendidikan Agama Islam pada masa Pandemi Covid-19. http://jurnal.uts.ac.id.

Manowong, S. (2016). Undergraduate students' perceptions of Edmodo as a supplementary learning tool in an EFL classroom. Humanities, Arts and Social Sciences Studies (Former Name Silpakorn University Journal of Social Sciences, Humanities, And Arts), 137-162.

Marzuki, A. G. (2019). Utilizing Recorded English Dialogues in Teaching English Word Stress to Islamic Higher Education Students in Indonesia. Jurnal Pendidikan Islam, 5(1), 53-64.

Marzuki, A.G. (2017). Developing Speaking Skill through Oral Report in an EFL Class in Indonesia, Al-Ta'lim Journal, 24(3), 243-254.

Morgan, H. (2020). Best practices for implementing remote learning during a pandemic. The Clearing House: A Journal of Educational Strategies, Issues and Ideas, 93(3), 135-141.

Octaberlina, L. R., \& Muslimin, A. I. (2020). Efl students perspective towards online learning barriers and alternatives using moodle/google classroom during covid-19 pandemic. International Journal of Higher Education, 9(6), 1-9.

Radha, R., Mahalakshmi, K., Kumar, V. S., \& Saravanakumar, A. R. (2020). E-Learning during lockdown of Covid-19 pandemic: A global 
perspective. International journal of control and automation, 13(4), 1088-1099.

Sujarwo, S., Sukmawati, S., Akhiruddin, A., Ridwan, R., \& Siradjuddin, S. S. S. (2020). An Analysis of University Students' Perspective on Online Learning in the Midst of Covid-19 Pandemic.Jurnal Pendidikan dan Pengajaran, 53(2), 125-137. 
108 | Yang Terdepan dalam Menghadapi Pembelajaran Daring 


\section{PEMBELAJARAN DARING DI MASA PANDEMI COVID 19 MELALUI APLIKASI SYAM-OK DI KAMPUS FIK UNM}

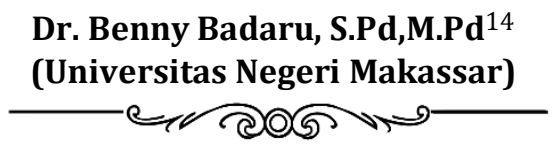

"Sebagai platform pembelajaran daring, LMS SYAM OK berupaya meningkatkan akses layanan pembelajaran yang dinamis dan terjangkau baik dalam lingkup civitas akademik UNM, seperti dosen dan mahasiswa dan terjangkau bagi dosen dan mahasiswa luar UNM"

Dembelajaran daring saat ini, semakin berkembang pesat, tidak hanya sekedar sebagai mengikuti trend erupsi revolusi teknologi informasi. Namun sangat dirasakan sebagai suatu mode utama terlebih ketika dipernadapkan pada situasi pandemi covid-19 yang

14 Penulis lahir di Ujung Pandang, 11 Oktober 1985, penulis merupakan Dosen Penjaskesrek FIK UNM dalam bidang ilmu Pendidikan Olahraga, penulis menyelesaikan gelar Sarjana Pendidikan di Universitas Negeri Makassar (2008), sedangkan gelar Magister Pendidikan diselesaikan di Universitas Negeri Makassar Program Studi Pendidikan Jasmani dan Olahraga (2010), dan akhirnya Doktor Ilmu Keolahragaan diselesaikan di Universitas Negeri Jakarta pada Program studi Pendidikan Olahraga (2017). 
mengharuskan belajar dilakukan dari rumah. Di kondisi normal, belajar daring diterapkan secara bended sehingga kedudukan adalah sebagai suplemen pembelajaran. Dikondisi sekarang, belajar daring digunakan sebagai replacement atau pengganti dari pelaksanaan tatap muka pembelajaran di kelas. Sistem pembelajaran daring (dalam jaringan) merupakan sistem pembelajaran tanpa tatap muka secara langsung antara guru dan siswa tetapi dilakukan melalui online yang menggunakan jaringan internet. pembelajaran secara daring yaitu proses pembelajaran yang memanfaatkan jaringan internet dalam proses pembelajaran (Isman, 2017).

Pembelajaran daring merupakan pembelajaran yang bertujuan untuk menjangkau kelompok yang masif dan luas dengan memanfaatkan jaringan internet (Yanti et al., 2020). Guru harus memastikan kegiatan belajar mengajar tetap berjalan, meskipun siswa berada di rumah. Solusinya, guru dituntut dapat mendesain media pembelajaran sebagai inovasi dengan memanfaatkan media daring (online). Patria dan Yulianto (2011) mengemukakan ada beberapa metode belajar yang dilakukan saat pembelajaran dari rumah, yaitu diantaranya pembelajaran daring. Pembelajaran daring merupakan metode pembejaran yang menggunakan teknologi dan jaringan internet mulai dari penggunaan Whatsapp, Google Classroom, Zoom atau aplikasi lainnya. Pembelajaranan daring dilakukan dengan memanfaatkan teknologi internet dengan sistem belajar jarak jauh, sehingga kegiatan belajar dan mengajar (KBM) tidak dilakukan secara tatap muka. Pembelajaran online dapat dilakukan dengan menggunakan beberapa media, baik media cetak (modul) maupun non cetak (audio atau video), komputer atau internet, siaran radio dan televisi. Padma dan Sukanesh (2011) yang menyebutkan pada pembelajaran daring peserta didik 
cenderung tidak berperan aktif dalam pembelajaran, sehingga pembelajaran terasa membosankan dan menurunkan semangat dan minat belajar siswa.

Integrasi Teknologi Informasi khususnya sistem pembelajaran secara daring, Universitas Negeri Makassar (UNM) telah memiliki sejarah dalam pelaksanaan pembelajaran daring dimulai sejak rilis tahun 2006 dengan nama eleraning.unm.ac.id, kemudian tahun 2012 berganti nama menjadi lms.unm.ac.id hingga tahun 2020. Memasuki awal perkuliahan semester ganjil tahun 2020, tepatnya pada tanggal 19 Agustus 2020, merespon kemajuan dan kemajemukan pembelajaran di era disrupsi teknologi informasi, UNM melaunching LMS SYAM.OK. Kehadiran LMS SYAM OK merupakan upaya panjang UNM dalam menjadikan kampus UNM sebagai kampus digital yang dapat memenuhi tuntutan kemajuan dan kebutuhan belajar di masa depan. Peluncuran Ims SYAM OK, sekaligus menandai awal digunakannya SYAM OK sebagai platform pembelajaran daring di UNM.

Sebagai platform pembelajaran daring, LMS SYAM OK berupaya meningkatkan akses layanan pembelajaran yang dinamis dan terjangkau baik dalam lingkup civitas akademik UNM, seperti dosen dan mahasiswa dan terjangkau bagi dosen dan mahasiswa luar UNM. Hal ini sejalan dengan semangat merdeka belajar dalam kaitan kesempatan untuk saling melakukan kuliah lintas program studi di luar kampus. Dalam memenuhi harapan pembelajaran daring di UNM, LMS SYAM OK mendorong perwujudan pembelajaran yang berpusat pada mahasiswa melalui aktivitas pembelajaran asinkronous secara mandiri maupun kolaboratif. Tentu dengan tetap mempertimbangkan kemandirian dan gaya belajar mahasiswa saat ini 
sebagai pembelajar yang kreatif, inovatif, dan kolaboratif.

Sebagai suatu pembelajaran daring baru, memahami sifat dan karakteristik LMSnya membutuhkan waktu dan adaptasi untuk akrab. Sebagai upaya memberikan pemahaman yang sama terhadap LMS SYAM OK, maka penulis melakukan kegiatan pelatihan tentang pembelajaran daring melalui aplikasi SYAM-OK di lingkup civitas Akademika FIK UNM, baik itu tenaga pendidik (dosen) maupun pada mahasiswa FIK UNM yang selaku pengguna aplikasi pembelajaran tersebut. Kehadiran kegiatan ini, harapannya dapat menjadi acuan bersama dalam melaksanakan pembelajaran daring yang memenuhi standar minimal kualitas pembelajaran daring yang dibuat oleh Kementerian Riset Teknologi dan Pendidikan Tinggi. Standar ini meliputi standar sistem, standar konten, dan standar proses yang dituangkan dalam buku pedoman pembelajaran SYAM OK.

Aplikasi pembelajaran daring yang dinamakan LMS SYAM OK yang akan disusun secara garis besar pokok materinya meliputi: 1) manajemen kelas; 2) manajemen materi; 3) manajemen aktivitas; 4) penilaian dan evaluasi dalam pembelajaran daring; dan 5) etika dalam pembelajaran daring. Panduan ini meliputi panduan untuk pengguna dosen dan pengguna mahasiswa. Untuk mahasiswa fokus pada bagaimana mengikuti perkuliahan daring, meliputi materi pada: 1) mengisi kehadiran, membaca dan mendownload materi, mengikuti forum diskusi, mengikuti video konferensi, mengelola tugas, dan mengikuti ujian. Panduan ini akan terus berkembang siring dinamikan perkembangan pembelajaran daring, Untuk saat ini, ketersediaan sumber-sumber belajar dalan LMS SYAM OK sudah cukup untuk melayani kebutuhan belajar mahasiswa 
dan dosen baik secara full daring maupun dalam sistem pembelajaran blended learning.

Aplikasi online bertujuan untuk melatih kemandirian siswa dan keaktifan siswa (Oknisih, et al., 2019). Menyadari akan kurangnya pengetahuan tentang pembelajaran daring melalui aplikasi SYAM OK pada lingkup civitas akademika FIK UNM, maka kami sebagai tenaga pendidik (dosen) bagian dari tim blended learning SYAM-OK ingin memberikan pelatihan secara terpadu kepada para dosen maupun mahasiswa FIK UNM yang ingin mengetahui dan mempelajari pengetahuan tentang pembelajaran daring SYAM OK. Dengan harapan bahwa setelah mereka dibekali pengetahuan tentang pembelajaran daring SYAM OK, maka diharapkan mereka dapat mengaplikasikan pengetahuan yang mereka dapatkan pada kegiatan proses belajar mengajar di FIK UNM.

Setelah SYAM-OK dilaunching pada 19 Agustus 2020, tim pengelola terus melakukan perbaikan fitur agar layanan ini dapat digunakan dengan mudah dan powerful. Berdasarkan informasi yang dihimpun, salah satu kendala yang dialami oleh dosen adalah mengenai pembuatan kelas dan memasukkan mahasiswa ke dalam kelas yang masih dilakukan secara manual. Hal tersebut di tindak lanjuti dengan mengembangkan sebuah aplikasi penghubung antara LMS SYAM-OK dengan Sistem Akademik UNM. Maka lahirlah aplikasi bernama Course Management System (CMS) SYAM-OK. Olehnya itu, saat ini pembuatan mata kuliah, pembagian grup kelas, sinkron mahasiswa, dan manajemen kelas dikelola melalui aplikasi ini. Untuk proses pembelajarannya, tetap menggunakan LMS SYAM-OK.

Pada umumnya platform yang dimiliki oleh UNM yaitu aplikasi pembelajaran daring (online) SYAM-OK yang digunakan selama di masa pandemic covid 19 
sangat mempengaruhi minat belajar mahasiswa karena merupakan aplikasi pembelajaran daring yang baru di lingkungan kampus FIK UNM. Kebanyakan mahasiswa lebih menyukai aplikasi Whatsapp dan Google Classroom karena tidak begitu banyak menyita kuota internet, tidak ribet dan memberikan dampak yang positif terhadap peningkatan hasil belajar, minat dan motivasi peserta didik dalam belajar serta menumbuhkan sikap kreatif pada peserta didik.

Selama pembelajaran daring, peserta didik sering mengalami kendala seperti jaringan internet tidak stabil, banyaknya tugas yang diberikan, sulit fokus serta aplikasi yang rumit, sehingga mahasiswa lebih senang dengan pembelajaran tatap muka apalagi dengan perkuliahan secara praktek seperti mata kuliah sepakbola, atletik, bulutangkis dan lain-lain. Pada dasarnya selama pandemi ini mahasiswa merindukan perkuliahan secara tatap muka, merindukan interaksiinteraksi nyata pada proses pembelajaran dan bukan hanya sekedar transfer materi dan tugas dari dosen pada mahasiswanya saat pembelajaran daring berlangsung.

Pembelajaran daring hendaknya tidak hanya berorientasi pada pemberian materi dan target pembelajaran akan tetapi juga harus berorientasi pendekatan personal guru kepada siswa didiknya baik pendekatan emosional maupun pendekatan kognitif. Waryanto (2006) menyatakan bahwa kelebihan dari penggunaan pembelajaran daring yaitu pembelajaran daring dapat digunakan dalam menyampaikan pembelajaran tidak terbatas ruang dan waktu. Selain itu, pembelajaran daring dapat menggunakan berbagai sumber belajar yang banyak tersedia di internet serta bahan ajar adalah dapat digunakan untuk menyampaikan pembelajaran tanpa dibatasi ruang dan 
waktu, dapat materi pembelajaran relatif mudah diperbaharui. Di samping itu, dengan dilakukannya pembelajaran daring dapat menjadikan mahasiswa lebih mandiri pada proses pembelajaran.

\section{DAFTAR PUSTAKA}

Isman, M. (2017). Pembelajaran Moda Dalam Jaringan (Moda Daring). The Progressive And Fun Education Seminar, 586-588.

Padma, A., dan Sukanesh, R. (2011). Meningkatkan Motivasi Belajar Siswa pada Pembelajaran Online Akibat Pandemi COVID-19. Automatic Classification and Segementation of Brain Tumor in CT Images Using Optimal Dominant Gray LLvel Run Length Texture Features, 2(10), 53-59.

Patria, L., dan Yulianto, K. (2011). Pemanfaatan Facebook Untuk Menunjang Kegiatan Belajar Mengajar Online Secara Mandiri. Prosiding Seminar Nasional FMIPA-UT 2011. http://repository.ut.ac.id/id/eprint/2305

Oknisih, Nur. Wahyuningsih, Yull, dan Suyoto. (2019). Penggunaan Aplen (Aplikasi Online) sebagai Upaya Kemandirian Belajar SIswa. Prosiding Seminar Nasional Pendidikan Dasar. Vol. 1. 477483.

http://eproceedings.umpwr.ac.id/index.php/sem naspgsd/article/view/1056

Yanti, M. T., Kuntarto, E., \& Kurniawan, A. R. (2020). Pemanfaatan Portal Rumah Belajar Kemendikbud Sebagai Model Pembelajaran Daring Di Sekolah Dasar. Adi Widya Jurnal Pendidikan Dasar, 10(1), 61-68. 
Waryanto, N. H. (2006). Online Learning sebagai salah satu Inovasi Pembelajaran. Jurnal Phitagoras, 2(1).

116 | Yang Terdepan dalam Menghadapi Pembelajaran Daring 


\title{
MODEL PEMBELAJARAN HIGHER ORDER THINKING SKILLS DALAM PENDIDIKAN JASMANI
}

\author{
Wahyu Indra Bayu ${ }^{15}$ \\ (Universitas Sriwijaya)

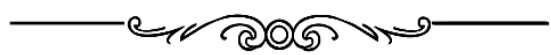

"HOTS mencakup pengelompokan, perbandingan, kontras ide, dan teori serta mampu memecahkan masalah. Salah satu pendekatan pembelajaran yang dapat meningkatkan aktivitas belajar siswa, meningkatkan keterampilan berpikir tingkat tinggi, dan menghubungkan pengetahuan yang telah mereka pelajari dengan masalah dunia nyata"

\begin{abstract}
Higher Order Thinking Skills (HOTS) adalah 1 komponen penting dari keterampilan Abad 21. Ini adalah keterampilan yang paling dibutuhkan dalam kehidupan saat ini. Yang termasuk dalam HOTS adalah keterampilan belajar diantaranya berpikir kritis, kreativitas, kolaborasi, dan komunikasi. HOTS mencakup pengelompokan, perbandingan, kontras ide,
\end{abstract}

\footnotetext{
${ }^{15}$ Penulis merupakan Dosen pada Program Studi S1 Pendidikan Jasmani dan Kesehatan dan S2 Pendidikan Olahraga FKIP Universitas Sriwijaya. Lahir dan besar di Kabupaten Jombang Jawa Timur, tepatnya di Kec. Sumobito. Menempuh pendidikan tinggi S1-S3 di Universitas Negeri Surabaya dari tahun 2005-2015.
} 
dan teori serta mampu memecahkan masalah. Salah satu pendekatan pembelajaran yang dapat meningkatkan aktivitas belajar siswa, meningkatkan keterampilan berpikir tingkat tinggi, dan menghubungkan pengetahuan yang telah mereka pelajari dengan masalah dunia nyata adalah pembelajaran berbasis masalah (PBL). Pembelajaran berbasis masalah (PBL) adalah strategi pembelajaran di mana peserta didik mencoba memecahkan masalah atau serangkaian masalah yang tidak mereka kenal. PBL memupuk pembelajaran mandiri, pemecahan masalah yang efektif, keterampilan komunikasi dan kolaborasi. Pendekatan PBL dapat membantu peserta didik mengembangkan pemikiran kritis dan kemampuan untuk memecahkan masalah secara mandiri. Peserta didik mengalami peningkatan kemampuan untuk mengidentifikasi masalah yang berkaitan dengan rekreasi dan pendidikan jasmani, serta membuat peserta didik menjadi lebih kreatif dalam memecahkan masalah (Chow, Tsai, \& Louie, 2008).

Selain PBL, dapat juga diterapkan pendekatan pembelajaran berbasis inkuiri dalam pendidikan jasmani. Pendekatan ini dapat merangsang dan melibatkan peserta didik dalam pembelajaran secara fisik dan kognitif. Inkuiri adalah pendekatan yang mempromosikan keterlibatan, motivasi dan pembelajaran, serta yang melibatkan penggunaan pengetahuan kognitif, pengalaman tubuh, dan keterampilan komunikatif. Inkuiri sebagai proses belajar peserta didik dapat dipertimbangkan dalam tiga tahap: meluncurkan, memfasilitasi, dan membuat inkuiri, dengan komponen proses inkuiri disertakan di setiap tahap. Sebagai bagian dari peluncuran inkuiri mereka, siswa merumuskan pertanyaan untuk mengeksplorasi dan menyelidiki topik mereka. Pengajar memfasilitasi komponen mengumpulkan dan mengatur 
saat siswa menafsirkan dan menganalisis apa yang telah mereka kumpulkan dalam penyelidikan. Setelah siswa mengumpulkan informasi dan bukti yang sesuai terkait dengan pertanyaan mereka, mereka dapat bergerak maju untuk memahami bukti mereka - mereka mengevaluasi dan menarik kesimpulan; komunikasikan apa yang telah mereka pelajari; dan merenungkan apa, mengapa, dan bagaimana mereka belajar. Meskipun tahapannya progresif, pendidik dapat memulai prosesnya pada tahap mana pun.

Hampir sama dengan pendekatan inkuiri, model pembelajaran Teaching Games for Understanding (TGfU) dapat diterapkan pada proses pembelajaran pendidikan jasmani untuk meningkatkan kemampuan berpikir tingkat tinggi (Memmert et al., 2015). TGfU dipahami sebagai pendekatan inkuiri untuk pengajaran game di mana bermain game diajarkan sebelum penyempurnaan keterampilan. Pendekatan TGFU telah mendorong debat tentang pengajaran permainan yang sering terpolarisasi menjadi argumen taktik keterampilan. TGfU adalah pendekatan dalam pembelajaran pendidikan jasmani yang dikembangkan oleh Peter Werner, David Bunker, dan Rod Thorpe, dan diadopsi pada tahun 2002 oleh sekelompok perwakilan, asosiasi dan individu dari seluruh dunia. Model Game Mengajar untuk Memahami menggabungkan 6 tahapan utama yang meliputi: (1) Fokus-Game, (2) Penghargaan Game, (3) Kesadaran Taktis, (4) Pengambilan Keputusan, (5) Eksekusi Keterampilan dan (6) Kinerja (Werner, Thorpe, \& Bunker, 1996). Pembeda TGfU dari model pembelajaran lainnya adalah adalah pendekatan yang digunakan. Kunci untuk guru/pelatih adalah teknik bertanya dan relevansinya dengan peserta didik tentang pengenalan aturan dan teknik. Fokusnya adalah pada peserta didik dan pemecahan masalah. Selain itu, kesenangan adalah bahan utamanya. TGfU adalah suatu pendekatan 
pengajaran yang memanfaatkan pembelajaran aktif dengan sangat efektif karena peserta didik belajar melalui permainan. Penggunaan pertanyaan adalah metode yang ampuh untuk mendorong peserta didik menganalisis tindakan mereka, baik secara individu, maupun sebagai tim. Pertanyaan umumnya akan berhubungan dengan aspek taktis tertentu. Frase pertanyaan yang efektif juga dapat membantu membimbing pemain ke jawaban, jika mereka berjuang dengan suatu aktivitas. Usia, pengalaman, dan tingkat kemampuan pemain akan mempengaruhi kompleksitas pertanyaan yang digunakan.

Pemikiran kritis dapat disesuaikan dengan domain fisik dalam dua cara (Tishman \& Perkins, 1995). Yang pertama melibatkan pemanfaatan peluang yang sudah ada di area pembelajaran dan yang kedua melibatkan penggunaan berbagai strategi yang tersedia untuk pembelajaran berpikir kritis. McBride, Gabbard, \& Miller, (1990) menyarankan bahwa banyak model pembelajaran yang berbeda, seperti Spectrum of Teaching Styles (Mosston \& Ashworth, 1990), tersedia untuk pendidik jasmani yang ingin mendorong siswanya untuk berpikir kritis. Banyak guru pendidikan jasmani sudah memasukkan keterampilan berpikir kritis dalam pengajaran mereka, mungkin tanpa mereka sadari. Berpikir kritis adalah istilah yang tidak berbentuk (Tan, 2017). Ini memiliki banyak interpretasi baik dalam definisi maupun proses yang terlibat dalam mengembangkan pemikiran kritis. Sebagian besar definisi menyoroti hubungan ke tiga tingkat teratas taksonomi Bloom: analisis, sintesis, dan evaluasi. Bentuk-bentuk keterampilan berpikir telah dikaitkan dengan sejumlah disposisi pelajar "berpikir kritis" termasuk; keterbukaan dan pemikiran yang adil, fleksibilitas pemikiran, keingintahuan dan kemauan untuk mengambil risiko (Lai, Bay-Borelli, Kirkpatrick, 
Lin, \& Wang, 2011). Dalam konteks pendidikan jasmani, Beni, Fletcher, \& Ní Chróinín, (2017) menjelaskan bagaimana peserta didik dengan pengalaman pribadi mereka dapat merasa lebih terhubung antara "makna" dari tugas-tugas belajar yang mereka dapatkan, serta memungkinkan untuk berkomitmen menerapkan gaya hidup aktif secara fisik.

Dalam rencana pembelajaran atau diskusi sebelum kelas dimulai dengan pengamat, guru harus secara spesifik menjelaskan kapan dan bagaimana berpikir kritis ditujukan dalam pembelajaran. Sebagian besar pengamat (biasanya kepala sekolah atau asisten kepala sekolah) digunakan untuk mengidentifikasi pembelajaran berpikir kritis di kelas, tetapi mungkin tidak memiliki pengetahuan yang luas secara prosedural yang diperlukan untuk mengenalinya dalam pemberian tugas gerak; jadi berdiskusi dengan pengamat bagaimana peserta didik terlibat secara kognitif dan kreatif, serta bagaimana pemeblajaran dirancang untuk mencapai semua standar, sangat disarankan. Peningkatan kapasitas pembelajaran pendidikan jasmani ketika diajarkan dengan penuh kesadaran, dengan kesadaran akan hasil yang diajarkan kepada peserta didik. Bahkan ketika tidak sedang dinilai, guru akan meningkatkan proses pembelajaran mereka jika mereka sadar dalam mengajar pada ranah kognitif, psikomotor, dan afektif.

Peserta didik juga dapat menggunakan banyak dari keterampilan berpikir kritis untuk melakukan tugas gerak dan menyelesaikan tugas tersebut selama pembelajaran pendidikan jasmani. Misalnya, dalam permainan sepak bola, seorang peserta didik mungkin bertanya, "Bagaimana cara menciptakan peluang untuk menghasilkan gol?" Dalam hal ini, peserta didik menganalisis situasi di lapangan, memilih tindakan yang 
mungkin dilakukan, memprediksi gerakan mana yang akan menghasilkan kesuksesan, dan kemudian mengevaluasi hasil dari pilihan yang dibuat. Keuntungan dari fokus pada berpikir kritis dalam pembelajaran pendidikan jasmani adalah dapat meningkatkan kesadaran peserta didik tentang pemikiran mereka sendiri dan sejauh mana keterampilan berpikir mereka efektif dalam membantu mereka untuk menjadi lebih terampil, bugar, dan berpengetahuan tentang aktivitas fisik.

Pemikiran kritis memang mendapat tempat dalam domain psikomotorik. Pendidikan jasmani dan lingkungan olahraga dapat memberikan lingkungan yang mendukung bagi individu untuk belajar bagaimana berpikir kritis. Sifat praktis dari aktivitas fisik memungkinkan individu untuk menerapkan strategi baru, mencoba gerakan baru, dan mengevaluasi nilai respons dengan segera. Peserta didik dapat ditantang untuk menghasilkan solusi unik untuk masalah gerakan, membuat versi baru dari permainan, dan memikirkan masalah yang berkaitan dengan kebugaran dan kesehatan. Namun, baik guru/pelatih dan peserta didik harus mampu mengenali peluang yang tersedia untuk menerapkan dan memanfaatkan pemikiran kritis. Namun, seperti yang dinyatakan sebelumnya, tantangannya adalah belajar mengenali kapan peluang ini tersedia. Akhirnya, terlepas dari strategi yang diajarkan atau kegiatan yang terlibat, guru harus bertindak sebagai fasilitator proses berpikir kritis. Guru mendorong kemampuan peserta didik untuk memusatkan perhatian mereka pada keputusan yang diperlukan untuk kinerja terampil. Melalui peran aktif ini, guru dapat membantu peserta didiknya dalam memanfaatkan berpikir kritis untuk pencapaian keberhasilan di bidang kebugaran dan gerak. 


\section{DAFTAR PUSTAKA}

Beni, S., Fletcher, T., \& Ní Chróinín, D. (2017). Meaningful experiences in physical education and youth sport: A review of the literature. Quest, 69(3), 291-312. https://doi.org/10.1080/00336297.2016.122419 2

Chow, B. C., Tsai, E. H. L., \& Louie, L. H. T. (2008). Application of Problem-based Learning for "Physical Education and Recreation Management" Courses. In Studies on Teaching and Learning (pp. 7-16). Hong Kong. Retrieved from https://repository.hkbu.edu.hk/phys_bkch

Lai, E., Bay-Borelli, M., Kirkpatrick, R., Lin, A., \& Wang, C. (2011). Critical Thinking: A Literature Review Research Report. London.

McBride, R. E., Gabbard, C. C., \& Miller, G. (1990). Teaching critical thinking skills in the psychomotor domain. The Clearing House, 63(5), 197-201. Retrieved from https://www.jstor.org/stable/30188469?seq=1

Memmert, D., Hillmann, W., Huttermann, S., KleinSoetebier, T., Konig, S., Nopp, S., ... Griffin, L. (2015). Top 10 research questions related to teaching games for understanding. Research Quarterly for Exercise and Sport, 86(4), 347-359. https://doi.org/10.1080/02701367.2015.108729 4

Mosston, M., \& Ashworth, S. (1990). The Spectrum of Teaching Styles: From Command to Discovery. New York: Longman, Inc. Retrieved from https://eric.ed.gov/?id=ED312266

Tan, C. (2017). Teaching critical thinking: Cultural challenges and strategies in Singapore. British 
Educational Research Journal, 43(5), 988-1002. https://doi.org/10.1002/berj.3295

Tishman, S., \& Perkins, D. N. (1995). Critical Thinking and Physical Education. Journal of Physical Education, Recreation \& Dance, 66(6), 24-30. https://doi.org/10.1080/07303084.1995.106070 94

Werner, P., Thorpe, R., \& Bunker, D. (1996). Teaching Games for Understanding: Evolution of a Model. Journal of Physical Education, Recreation \& Dance, 67(1), 28-33. https://doi.org/10.1080/07303084.1996.106071 76 


\title{
PEMANFAATAN MEDIA PADLET DALAM PEMBELAJARAN MENULIS TEKS EKSPLANASI PADA SISWA KELAS XI SMA
}

\author{
Ulfah Mey Lida, M.Pd. ${ }^{16}$ \\ (IAIN Kudus)

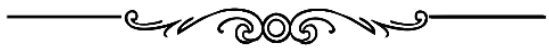

"Mulang Bahasa Indonesia penak ya, gampang. Rak sah nganggo itung-itungan. Bocah diwenehi tugas ning WA ngono wis iso ngerjakke. Iso disambi nyekel penggehan liyo. Penak. Mulang 30 JP yo rak krasa"

\begin{tabular}{l} 
Begitulah celetuk rekan pendidik dari mata pelajaran \\
lain, yang menganggap bahwa pembelajaran Bahasa \\
Indonesia itu gampang untuk era Pembelajaran Jarak \\
Jauh (PJJ) seperti saat ini. Anggapan semacam ini \\
memang kerap terlontar dari mereka yang memahami \\
pelajaran Bahasa Indonesia ini secara awam. Padahal, \\
tiap mata pelajaran memiliki tingkat pencapaian yang \\
sejajar sesuai dengan jenjang pendidikannya. Tiap-tiap \\
\hline 16 Penulis lahir di Demak, 05 Mei 1992, penulis merupakan Dosen \\
IAIN Kudus dalam bidang Pendidikan Bahasa Indonesia. Penulis \\
menyelesaikan gelar Sarjana Pendidikan Bahasa dan Sastra Indonesia di \\
Universitas Negeri Semarang (2013). Adapun gelar Magister Pendidikan \\
Bahasa Indonesia diselesaikan juga di Universitas Negeri Semarang \\
(2017).
\end{tabular} 
pendidik juga berkewajiban untuk memfasilitasi peserta didiknya untuk dapat mencapai tolok ukur pemahaman materi yang sudah ditentukan.

Di era pandemi seperti ini, guru dituntut untuk dapat menyesuaikan pembelajaran dengan kondisi yang ada. Kebijakan belajar di rumah membuat semua metode, strategi, dan pendekatan pembelajaran yang semula dapat diterapkan untuk pembelajaran di kelas menjadi tidak relevan lagi. Kelas merupakan tempat siswa mengeksplor kemampuan-kemampuan yang dimiliki dengan berbagai kegiatan-kegiatan belajar yang difasilitasi oleh guru. Saat ini, ruang kelas bertransformasi menjadi kelas virtual pada platform digital. Hal ini berlaku untuk semua mata pelajaran, tidak terkecuali Bahasa Indonesia.

Menulis Teks Eksplanasi merupakan salah satu materi yang harus dikuasai oleh siswa kelas XI SMA. Priyanti dalam Supriyanto (2009: 23) menjelaskan bahwa teks eksplanasi merupakan teks yang memuat konten-konten tentang proses yang berhubungan dengan fenomena alam, ilmu budaya, sosial, dan topiktopik lainnya. Teks ini memaparkan kejadian secara faktual yang mencakup apa, di mana, kapan, siapa, dan bagaimana. Dalam materi ini, siswa diharapkan dapat menjelaskan proses atau fenomena alam dan sosial. Menurut hasil penelitian Supriyanto (2019: 23), siswa justru tidak tertarik dan tidak memiliki motivasi untuk menulis teks eksplanasi. Hal ini dikarenakan keterampilan dan motivasi menulis siswa masih rendah.

Era PJJ semacam ini memang menuntut guru lebih ekstra, agar dapat memicu semangat dan motivasi siswa dalam belajar. Jika pembelajaran hanya menggunakan Whatsapp (WA) saja, tentu siswa akan merasa bosan dan cenderung menyepelekan. Terlebih jika guru tidak 
memberikan feedback untuk setiap tugas yang dikerjakan siswa.

Hal ini akan menjadi berbeda jika guru memanfaatkan teknologi yang tersedia. Saat ini, ada ribuaan platform digital yang dapat dimanfaatkan untuk pembelajaran. Salah satunya yaitu Padlet. Platform digital ini merupakan salah satu aplikasi daring yang menyerupai papan tulis. Aplikasi ini dapat diakses secara gratis oleh siapa saja, dengan menuliskan laman padlet.com di address bar browser. Berikut ini merupakan tampilan beranda Padlet.

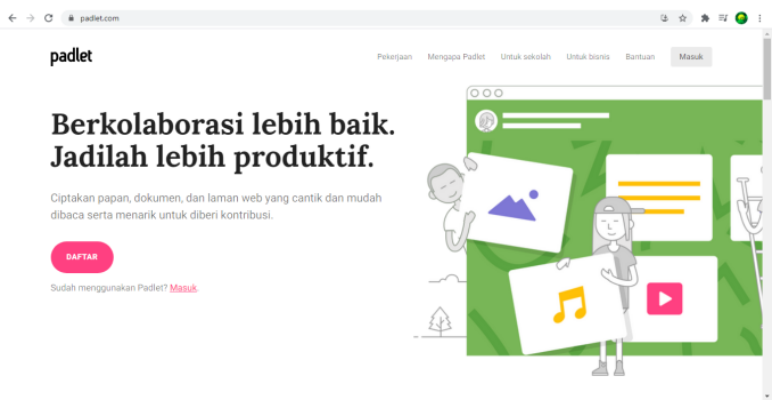

Gambar 1. Halaman beranda Padlet

Padlet dapat digunakan di semua perangkat yang mendukung internet, seperti komputer, laptop, tablet, smartphone, dll. Di era daring semacam ini sangat memungkinkan memanfaatkan Padlet dalam pembelajaran jarak jauh, termasuk dalam pembelajaran menulis teks eksplanasi.

Berdasarkan hasil observasi yang dilakukan, sebagian besar guru belum menggunakan media yang inovatif dalam pembelajaran menulis teks eksplanasi. Alih-alih memanfaatkan teknologi, guru lebih nyaman meminta siswa menulis di buku tugasnya, lalu memintanya untuk memfoto dan mengunggahnya di 
WA atau platform kelas digital. Hal ini seperti memadukan pembelajaran konvensional dengan pembelajaran daring. Cukup ironis, perkembangan teknologi yang pesat ini tidak diimbangi dengan perkembangan SDMnya.

Memanfaatkan media Padlet dalam pembelajaran menulis teks eksplanasi pada siswa kelas XI SMA dapat menjadi salah satu cara dalam meningkatkan daya tarik dan semangat belajar siswa. Untuk mengaplikasikannya, hal pertama yang harus dilakukan adalah membuka laman padlet.com terlebih dahulu. Kemudian masuk menggunakan akun Google. Ini menjadi salah satu kelebihan dari Padlet, yaitu terintegrasi dengan jaringan terbesar di dunia yang semua orang pasti memiliki akun di dalamnya, sehingga baik siswa maupun guru tidak perlu mendaftar sebagai member Padlet untuk dapat menikmati fasilitas di dalamnya.

Ketika sudah masuk, pilih menu "Buat Padlet" untuk membuat lembar papan tulis baru. Setelah itu akan diminta untuk memilih gaya papan tulis yang diinginkan. Terdapat delapan gaya yang dapat dipilih sesuai dengan kebutuhan.

Selamat Hari Jumat!
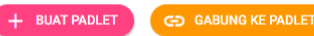

Q: GALERI

TINGKATKAN

Gambar 3. Pilih "Buat Padlet"

128 | Yang Terdepan dalam Menghadapi Pembelajaran Daring 


\begin{tabular}{l} 
Masuk ke Padlet \\
Belum punya akun Padlet? Daftar \\
\hline G Masuk dengan Google \\
\hline Masuk dengan Microsoft \\
\hline Masuk dengan Apple \\
\hline Email atau nama pengguna \\
Email atau nama pengguna \\
\hline Kata sandi \\
Kata sandi \\
\hline
\end{tabular}

Gambar 2. Masuk dengan akun google

Buat padlet

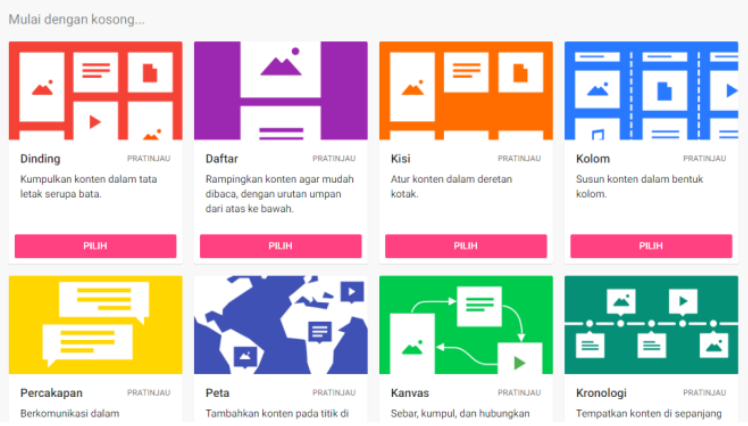

Gambar 4. Pilihan gaya papan tulis

Menulis teks eksplanasi berfokus pada praktik menulis yang dilakukan oleh siswa. Pada media Padlet, gaya papan tulis yang tepat untuk memfasilitasi praktik menulis siswa yaitu gaya "kisi". Gaya ini mengatur

Yang Terdepan dalam Menghadapi Pembelajaran Daring | 129 
konten secara berjajar dalam satu lembar papan tulis. Dalam hal ini, teks eksplanasi siswa menjadi konten dalam Padlet.

Saat lembar papan tulis sudah terbuat, terlebih dahulu sesuaikan dengan materi yang akan diajarkan. Pada kolom pengaturan, terdapat pilihan untuk mengganti judul papan tulis, deskripsi papan tulis, gambar latar papan tulis, jenis huruf, dan pilihan reaksi postingan. Reaksi yang dimaksud meliputi emotikon, suka, nilai, dan komentar. Pengaturan ini membuat papan tulis daring menjadi interaktif, baik antara guru dengan siswa, maupun siswa dengan siswa.

Padlet yang sudah diatur ini harus dibagikan kepada siswa agar mereka dapat menulis di dalamnya. Siswa dapat mengaksesnya melalui laptop maupun smartphone, sehingga mereka dapat menulis teks eksplanasi di mana pun dan kapan pun. Dalam papan tulis daring ini, siswa dapat menambahkan gambar, suara, dan video dalam teks eksplanasi yang mereka tulis, sehingga fenomena yang mereka tuliskan lebih menarik dan faktual. Dokumen yang dilampirkan tersebut dapat berasal dari dokumen pribadi, perekaman langsung, bahkan dapat mengambil dari laman pencarian daring.

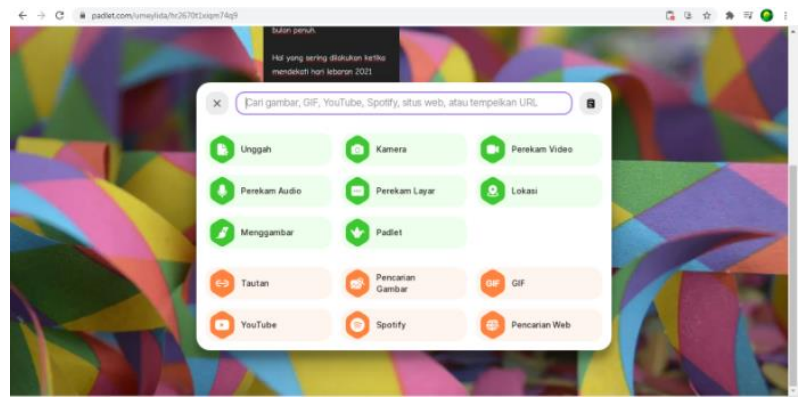

Gambar 5. Pilihan lampiran dokumen 
Dengan memanfaatkan Padlet, semua teks eksplanasi yang ditulis siswa terpampang dalam papan tulis daring, sehingga masing-masing siswa dapat membaca tulisan temannya. Selain itu, mereka juga dapat memberikan komentar dan penilaian terhadap karya tersebut.

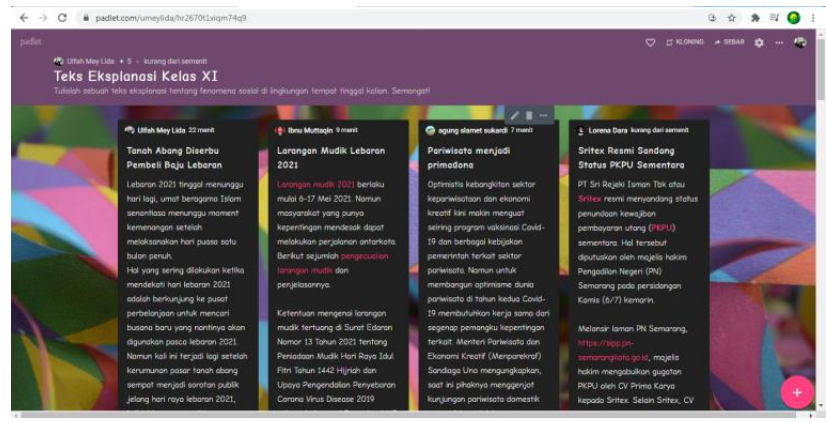

Gambar 6. Tampilan Teks Eksplanasi Siswa dalam Padlet

Dengan demikian, pemanfaatan media Padlet dalam pembelajaran menulis teks eksplanasi pada siswa kelas XI SMA ini dapat memberikan fasilitas praktik menulis, selain itu juga memberikan ruang pameran karya. Siswa satu dengan yang lainnya dapat saling menikmati, memberi masukan, serta menilai karya orang lain. Media Padlet ini sangat menunjang Pembelajaran Jarak Jauh menulis teks eksplanasi. Oleh sebab itu, diharapkan setiap guru dapat memaksimalkan penggunaan media daring, baik Padlet maupun media daring lainnya.

\section{DAFTAR PUSTAKA}

Purwanto, Agus Rudi. 2020. "Menggunakan Padlet sebagai E-Learning yang Sederhana". (https://dinaspdank.wonogirikab.go.id/wp- 
content/uploads/2020/03/Padlet-

Presentation.pdf) Diakses pada Jumat, 7 Mei 2021) pukul 09.30 WIB.

Suprianto, Edy. 2019. Implementasi Media Audio Visual untuk Meningkatkan Kemampuan Menulis Teks Eksplanasi. Trapsila: Jurnal Pendidikan Dasar. Desember 2019; 1(2); 22-32. 


\title{
KOLABORASI PEMBELAJARAN DARING DAN LURING DALAM MENINGKATKAN HASIL BELAJAR MATEMATIKA DI ERA PANDEMI COVID-19
}

\author{
Rina Gustini, S.Pd ${ }^{17}$ \\ (MAN 2 Cilacap)

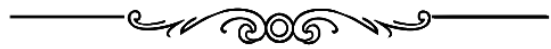

"Kegiatan tatap muka dengan guru tidak dapat digantikan dengan aplikasi dan melalui pembelajaran daring (online)"

\begin{abstract}
Derkembagan ilmu pengetahuan dewasa ini mengharuskan dunia pendidikan untuk selalu meningkatkan peningkatan mutunya dalam segala bidang. Oleh karena itu upaya peningkatan mutu pendidikan sudah merupakan kesepakatan nasional seperti yang tertuang dalam Undang-undang Sisdiknas No 20 tahun 2003 dan undang -undang Rebublik Indonesia No 14 tahun 2005 tentang guru dan dosen. Berbagai terobosan di luncurkan untuk meningkatkan kemampuan guru dan siswa termasuk dengan giat giatnya meningkatkan kemampuan guru dan siswa dalam penguasaan IT sehingga dapat melaksanakan
\end{abstract}

17 Penulis lahir di Pariaman, 12 Agustus 1973 merupakan Guru di MAN 2 Cilacap 
pembelajaran jarak jauh yang memanfaatkan media internet dan aplikasi pembelajaran jarak jauh seperti Google classroom, whatts app, telegram, Edmodo, Zoom, Google Meet dan masih banyak lagi yang lainnya.

Pandemi Covid-19 yang datang tanpa bisa di tolak telah merubah sebagian besar aspek kehidupan manusia, dan tak luput juga mempengaruhi aspek pendidikan. Kebijakan social distancing ( menjaga jarak ) dalam rangka menghambat penyebaran virus corona telah memaksa pembelajaran dilakukan ecara online (daring ) dengan memanfaatkan aplikasi dan media social yang bisa diakses secara online.

Pembelajaran daring merupakan pembelajaran yang dilakukan menggunakan internet sebagai tempat menyalurkan ilmu pengetahuan. Bentuk pembelajran seperti ini dapat dilakukan kapanpun dan dimanapun tanpa terikat waktu dan tanpa harus bertatap muka. Di era perkembangan teknologi pembelajaran daring semakin canggih dengan berbagai aplikasi dan fitur yang semakin memudahkan pengguna seperti Google classroom, whatts app, telegram, Edmodo, Zoom, Google Meet dan masih banyak lagi yang lainnya. Tidak terikatnya waktu dan dilakukan tanpa bertatap muka menjadi keunggulan pembelajaran daring yang bisa dimanfaatkan pendidik . Seperti yang terjadi pada saat ini, pembelajaran daring menjadi salah satu pilihan bentuk pembelajaran yang dapat dilakukan oleh pendidik untuk menyiasati kendala pandemic yang entah kapan akan berakhir. Indonesia menerapkan social distance di segala aspek kehidupan termasuk dunia pendidikan. Oleh karena itu, pembelajaran daring dapat dikatakan menjadi salah satu pilihan pembelajaran yang sangat mungkin dipilih dan dilakukan oleh pendidik agar bisa tetap 
melaksanakan proses belajar mengajar dan berinteraksi dengan siswa siswa bimbingannya.

Sistem pembelajaran dilaksanakan melalui perangkat personal computer (PC), Laptop atau handphone yang terhubung dengan koneksi jaringan internet. Guru dapat melakukan pembelajaran bersama diwaktu yang sama menggunakan grup di media sosial seperti WhatsApp, telegram, Aplikasi Zoom Cloud Meeting ataupun media lainnya. Dengan demikian, guru dapat memastikan siswa mengikuti pembelajaran dalam waktu yang bersamaan, meskipun di tempat yang berbeda. Dilihat dari kejadian sekitar yang sedang terjadi, baik siswa maupun orangtua siswa yang tidak memiliki handphone yang memadai untuk menunjang kegiatan pembelajaran daring (online) ini merasa kebingungan,sehingga pihak sekolah ikut mencari solusi untuk mengantisipasi hal tersebut. Beberapa siswa yang tidak memiliki handphone melakukan pembelajaran secara berkelompok, sehingga mereka melakukan aktifitas pembelajaran pun bersama. Mulai belajar melalui videocall yang dihubungkan dengan guru yang bersangkutan, diberi materi-materinya pun dalam bentuk video yang berdurasi kurang dari 2 menit.

Matematika adalah salah satu pelajaran yang di ajarkan di sekolah, dan tak luput dari dampak wabah covid. Ikut melakukan pembelajaran jarak jauh, sementara matematika adalah materi pembelajaran yang abstrak yang cukup sulit untuk di pahami sebagian besar siswa tanpa bimbingan guru secara tatap muka (luring ).

Matematika Secara umum memiliki karakteristik :

1. Memiliki objek kajian yang abstrak,

2. Mengacu pada kesepakatan, 


\section{Berpola pikir deduktif,}

4. Konsisten dalam sistemnya,

5. Memiliki simbol yang kosong dari arti,

6. Memperhatikan semesta pembicaraan.

Obyek matematika bersifat abstrak, maka belajar matematika memerlukan daya nalar yang tinggi. Demikian pula dalam mengajar matematika guru harus mampu mengabstraksikan obyek-obyek matematika dengan baik sehingga siswa dapat memahami obyek matematika yang diajarkan. Belajar matematika merupakan kegiatan mental yang tinggi. Sehingga dalam mengajar matematika guru harus mampu memberikan penjelasan dengan baik sehingga konsep-konsep matematika yang abstrak dapat dipahami siswa. Keabstrakan matematika adalah salah satu penyebab matematika menjadi mata pelajaran yang cukup sulit untuk dapat dipahami sebagian besar siswa yang memiliki tahap pembelajaran konkret. Ini menjadi kendala utama dalam pembelajaran daring yang tidak memungkinkan terjadinya tatap muka dan interaksi antara siswa dan guru secara langsung.

Menyiasati banyaknya problem yang di hadapi, beberapa guru yang berbaung di beberapa madrasah mencoba untuk mencari solusi supaya proses fisycal distance tetap terlaksana dan materi matematika yang abstrak tetap dapat dipahami oleh siswa. Salah satu cara yang dilaukan adalah melakukan kegiatan pembelajaran bervariasi antara daring dan luring. Dimana siswa di bagi menjadi beberapa kelompok sehingga saat terjadi pertemuan tatap muka tetap bisa menjaga protokol kesehatan dan materi pelajaran juga bisa disampaikan dengan baik.

Pembelajaran luring di lakukan perkelompok dan di lakukan saat guru akan menjelaskan materi yang 
bersifat konsep dan abstrak, yang di perkirakan akan sulit untuk di pahami oleh siswa secara mandiri. Ini bertujuan agar siswa menguasai konsep awal dengan baik sehingga materi berikutnya siswa bisa memahami secara mandiri atau dengan bantuan video tutorial yang dikirim guru melalui pembelajaran daring.

Pembelajaran daring di lakukan untuk melengkapi pembelajaran luring. Materi yang sekiranya bisa dipahami tanpa kehadiran guru disampaikan secara online atau daring. Termasuk latihan soal soal soal untuk memperlancar siswa dalam mengerjakan soal soal. Pembelajaran daring memanfaatkan berbagai aplikasi atau media social yang ada yang sdh cukup di kenal oleh siswa.

Belajar dalam kelas (luring) dan belajar dari mana saja (daring) tentunya punya kelebihan dan kekurangan masing masing. Oleh karena itu maka kolaborasi kedua cara pembelajaran ini akan menutupi dan melengkapi kekurangan dan kelemahan masing masing.

Kelebihan pembelajaran kolaborasi luring dan daring adalah sbb:

1. Tetap bisa melaksanakan protokol kesehatan secara ketat dan menjaga jarak karena siswa yang datang saat tatap muka bergiliran sesuai jadwal kelompoknya, ini memungkinkan guru membuat kelompok sesuai sarana dan prasarana yang tersedia dan memperhatikan protokol kesehatan

2. Siswa tidak harus setiap hari berangkat ke sekolah, Berangkat ke sekolah hanya pada saat pembelajaran luring saja

3. Hemat biaya, buku buku pelajaran bisa didapat berupa soft copy sehingga siswa tidak perlu untuk membeli buku yang harganya relative mahal. 
4. Materi pembelajaran bisa lebih interaktif dan lebih menarik, bisa di berikan dalam bentuk video atau game yang biasanya lebih di gemari oleh siswa.

5. Soal soal latihan yang bisa di kemas dalam bentuk permainan interaktif di harapkan akan menarik minat siswa untuk lebih tertantang memahami materi pembelajaran sebagai upaya memenangkan permainan yang dimainkan.

Pelajaran yang dipetik dari dunia pendidikan di tengah pandemi ini, yakni kegiatan tatap muka dengan guru tidak dapa di gantikan dengan aplikasi dan pembelajaran daring (online). Beberapa guru di sekolah mengaku, jika pembelajaran daring ini tidak seefektif kegiatan pembelajaran konvensional (tatap muka langsung), karena beberapa materi harus dijelaskan secara langsung dan lebih lengkap. Pembelajaran daring hanya efektif untuk memberikan penugasan dan kolaborasi antara luring dan daring di harapkan akan mampu menjadi solusi bagi proses belajar mengajar dan meminimalisir kesulitan dan permasalahan yang ada diantara guru, siswa dan orang tua.

\section{DAFTAR PUSTAKA}

Basri, Hasan. 2013 Landasa Pendidikan. Bandung: Pustaka Setia.

Majid, Abdul. 2011. Perencanaan Pembelajaran. Bandung: Remaja Rosadakarya.

Mulyasa. 2013. Pengembangan dan Implementasi Kurikulum 2013. Bandung: Remaja Rosadakarya

Suyono dan Hariyanto. 2011. Belajar dan Pembelajaran. Bandung: Remaja Rosadakarya 


\title{
IMPLEMENTASI TEORI CITRA DA'I DALAM MENGEMBANGKAN EKSISTENSI DAKWAH DI MASA PANDEMI
}

\author{
Siti Marlida, M.Ag ${ }^{18}$ \\ (Universitas Muhammadiyah Bandung)

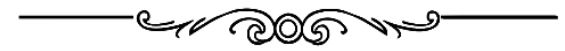

"Da'i sebagai unsur utama dan subyek dakwah dalam menyampaikan misi ajaran Islam memegang kendali penuh aktifitas dakwah"

Slam adalah agama yang identik dengan dakwah,. Dakwah menjadi sumbu yang menyalakan hidupnya izzatul Islam .Ketika aktiftas dakwah konsisten digerakkan maka nilai nilai ajaran Islam dapat ditegakkan dan disebarkan ke seluruh penjuru dunia secara intensif. Dakwah adalah internalisasi ajaran Islam kepada seluruh umat manusia di muka bumi ini . Dakwah akan sukses apabila disampaikan dengan memperhatikan kesempurnaan unsur unsur dakwah.

\footnotetext{
${ }^{18}$ Penulis lahir di Bekasi 17 Oktober 1970, penulis adalah dosen di Universitas Muhammadiyah Bandung dalam bidang ilmu Dakwah.Penulis menyelesaikan gelar Sarjana Bahasa Arab di Institut Agama Islam Negeri tahun 1995 sedangkan gelar Sajana Ilmu Dakwah di selesaikan di Universitas Islam Negeri Bandung tahun 2010. Selain mengajar, aktifitas penulis saat ini sebagai pengisi berbagai Majlis Taklim dan mengelola yayasan Pendidikan
} 
Diantara unsur-unsur tersebut yaitu da'i (pelaku dakwah),mad'u (obyek dakwah),madah (materi dakwah),wasilah (media dakwah), metode ( thoriqoh dakwah) dan atsar (efek dakwah). Adapun Unsur yang sangat menentukan keberhasilan dakwah adalah unsur da'i. M.Munir \& Wahyu Wahyuni mengatakan bahwa da'i adalah orang-orang yang melaksanakan dakwah baik lisan, tulisan, maupun perbuatan yang dilakukan baik secara individu, kelompok atau lewat organisasi dan lembaga.

Mengapa harus unsur da'i? Karena dakwah adalah sebuah proses yang harus disiapkan secara professional, komprehensif dan sistematis agar misi dakwah bisa dilaksanakan lebih efektif dan efisien kepada umat. Selain itu, perjalanan dakwah sejak zaman nabi Muhammad SAW sampai hari ini menghadapi banyak tantangan dan problema yang semakin berat sehingga dakwah perlu dikemas dengan penuh kehati-hatian dan ketelitian agar Islam tetap menjadi agama rahmatan lil-aalamiin. .

Menurut Samsul Munir Amin ( 2008:29) Sebagai suatu proses, dakwah tidak hanya merupakan usaha penyampaian, tetapi merupakan usaha mengubah way of thinking, way of feeling, way of life manusia sebagai sasaran dakwah ke arah kualitas kehidupan yang lebih baik Oleh karena itu kehadiran seorang Da'i yang berkualitas dan memiliki kompetensi professional dalam menyampaikan dakwah nya sangat dibutuhkan.

Menurut Hamzah Ya'qub (1981:37). bahwa dalam kegiatan dakwah, peranan da'i sangatlah esensial, sebab tanpa da'i, ajaran Islam hanyalah ideologi yang tidak terwujud dalam kehidupan masyarakat. "Biar bagaimanapun baiknya ideologi Islam yang harus disebarkan di masyarakat, ia akan tetap sebagai ide, ia 
akan tetap sebagai cita-cita yang tidak terwujud jika tidak ada manusia yang menyebarkannya.

Untuk mewujudkan da'i yang berkualitas dan profesional, tentu tidak hanya cukup mengandalkan pemahaman bahan materi yang akan disampaikan saja. Kompetensi da'i harus ditunjang pula oleh beberapa kriteria lain nya yang bisa menjad standar penilaian bersama. Ada dua kriteria dasar yang merupakan syarat penting dan harus dimiliki oleh siapapun yang berkomitmen menekuni jalan dakwah sebagai seorang da'i. Kriteria pertama adalah keilmuwan seorang da'i dan kriteria kedua adalah karakeristik atau kerpibadian seorang da'i.

Da'i sebagai unsur utama dan subyek dakwah dalam menyampaikan misi ajaran Islam memegang kendali penuh aktifitas dakwah. Da'i harus betul betul memperhatikan keluasan \&kualitas keilmuwan nya dan kemuliaan kepribadiannya. Dengan kualitas keilmuwan dan kepribadian yang baik, seorang da'i mampu memberikan kesan, kepercayaan dan citra yang positif di mata mad'u baik secara individu atau masyarakat. Sebagaimana kita lihat dalam perjalanan sejarah dakwah nabi Muhammad SAW dan para Khulafauurasyidin. Mereka betul betul mengamalkan ajaran Islam dalam setiap aspek kehidupan. Kepribadian nabi Muhammad SAW yang mencerminkan kesesuaian antara perkatan dan perbuatan senanatiasa selaras dengan isi ajaran Islam yang didakwahkan oleh nabi . Keteladanan nabi menjadi magnet dan daya Tarik masyarakat Arab berbondong-bondong rela bersyahadat meerima Islam sebagai keyakinan hidup mereka.. Keteladanan nabi Muhammad SAW menjadi rahasia dan power dakwah yang dilanjutkan oleh para sahabat dan generasi berikut nya. 
Seiring perjalanan dakwah yang sangat panjang,maka lahirlah Ilmu dakwah sebagai upaya para ilmuwan dakwah memberikan bekal referensi yang sangat penting bagi para pelaku dakwah atau da'i agar mereka selalu memperbaharui wawasan dan kemampuan nya dalam berdakwah. Dalam bangunan ilmu dakwah tersebut, para ilmuwan dakwah telah mengembangkan beragam teori diantara nya teori citra Da'i. Teori ini menguraikan konsep-konsep bagaimana seorang da'i membangun jati diri nya sebagai seorang pendakwah.

Secara bahasa citra dapat diartikan sebagai gambar atau gambaran, sedangkan secara istilah citra adalah gambaran yg dimiliki orang banyak mengenai pribadi, perusahaan, organisasi, maupun produk atau citra dapat juga diartikan suatu kesan kuat yang melekat pada banyak orang tentang seseorang, sekelompok orang atau tentang suatu institusi.

Menurut Enjang AS \& Aliyah Teori citra da'i menjelaskan penilaian mad'u terhadap kredibilitas da'i apakah da'i mendapat penilaian positif atau negatif, dimata mad'unya. Persepsi mad'u baik positif maupun negatif sangat berkaitan erat dengan penentuan penerimaan informasi atau pesan yang disampaikan da'i. Semakin tinggi kredibilitas da'i maka semakin mudah mad'u menerima pesan-pesan yang disampaikannya, begitu juga sebaliknya. Demikian pula pendapat Sayyid Sabiq memberikan kerangka pemikiran dalam mempertegas citra seorang da'i.. pertama Aspek moralitas yang baik bagi seorang da'i guna menunjang dakwah menjadi lebih produktif kedua mempersiapkan diri dalam intelektualitas. Selain itu Banyak hal yang harus dibekali oleh juru dakwah seiring dengan kemajuan di bidang sains dan teknologi yang sedemikian pesatnya. 
Kredibilitas menurut Oxford Dictionary bermakna (kualitas pribadi yang dapat dipercaya). Suatu kepribadian baru dapat dipercaya atau memiliki kredibilitas apabila ia secara konstan dan konsisten selalu menjaga ucapannya selaras dengan perilaku kesehariannya. Jalaluddin Rahmat menjelaskan dalam wacana ilmu komunikasi, citra itu semakna dengan kredibilitas,yaitu seperangkat persepsi komunikan tentang sifat-sifat yang terdapat pada komunikator.

Kredibiltas atau citra seorang da'i dapat dinilai dari beberapa faktor diantara nya:

1. Reputasi da'i dari jejak jejak karya,sikap dan prilaku sebelumnya

2. Cara da'i dalam mnegenalkan diri nya pada masyarakat

3. Ungkapan pemilihan kata dan bahasa yang digunakan,menjadi daya tarik kesan mad'u

4. Sistematika da'i dalam menyampaikan materi yang sesuai dengan kebutuhan mad'u

5. Kemampuan da'i dalam menggunakan metode dan media dakwah

Enjang AS \& Wahyu Wahyuni merumuskan citra positif da'i menjadi tiga dimensi yaitu:

1. Adanya kebersihan hati da'i dari sifat sifat syirik \& penyakit hati

2. Adanya kecerdasan mental dalam mengkondisikan batin nya agar selalu ikhlas \& tawakkal

3. Adanya keberanian mental dalam menyampaikan kebenaran 
Sejak terjadi nya wabah covid yang menyebar luas ke seluruh penjuru dunia, menyebabkan banyak perubahan di berbagai sector kehidupan. Semua aktifitas menjadi terbatas dan banyak sekat yang menghambat interaksi manusia secara langsung demi menjaga protokoler kesehatan dan menghindari penularan virus covid 19 semakin tak terkendali. Beragam upaya dilakukan masyarakat untuk mensiasati dampak pandemi yang luar biasa berat nya dengan mencari solusi dan berinovasi agar sektor-sektor kehidupan yang ditekuni tetap bisa dijalani sebaik mungkin. Demikian pula dengan dakwah yang merupakan sumbu hidup nya agama Islam di muka bumi ,Dampak pandemi menyebabkan aktifitas dakwah menjadi terhenti dan kehilangan arah karena fungsi masjid sebagai sentral ibadah ditutup total sehingga dakwah yang biasa nya dilakukan secara "Face to Face" antara da'i \& mad'u tidak dapat dilaksanakan. Lalu apa yang harus kita lakukan agar eksi .Diantara upaya yang bisa kita lakukan agar eksistensi dakwah terus berlangsung terutama di masa pandemi ini adalah dengan mengimplementasikan teori citra da'i secara maksimal. Ada dua langkah yang harus dilakukan oleh para da'i yaitu:

1. Lakukan evaluasi secara integral \& komprehensif

Para da'i harus mengevaluasi kinerja dakwah nya ketika sebelum pandemi lalu membuat peta perbandingan dengan kondisi obyektif saat pandemi sekarang ini. Apa aktiftas dakwah yang masih bisa dilanjutkan? Apa konsep dakwah yang harus diperbaharui? Dan yang lebih penting lagi para da'i harus memperbaiki karakter dan menyempurnakan ahlak kepribadian nya sesuai dengan ajaran Islam serta menerapkan teori citra da'i karena kredibilitas seorang da'i dalam pandangan mad'u sangat 
dipengaruhi oleh kepribadian nya, penampilan nya serta keluasan ilmu nya. Keteladanan seorang da'i lebih berkesan dan menggugah hati mad'u sebagaimana pepatah Arab mengatakan 'Lisanul Hal afshohu min lisaanil maqol" artinya Bahasa prilaku lebih tajam dari bahasa lidah.

2. Lakukan aksi personal branding da'i

Dampak pandemi menyebabkan aktiftas dan interaksi antar manusia banyak dilakukan menggunakan koneksi internet melalui dunia maya. Segala sesuatu akan terhubung bila kita menggunakan jaringan internet, tak lagi dipisahkan oleh jarak dan waktu semua bisa dikendalikan dan dikontrol dalam sentuhan jemari. Walaupun banyak tanggapan negative dengan perubahan kebiasaan ini namun mau tak mau masyarakat harus beradaptasi dengan cepat agar bisa memenuhi kebutuhan nya baik dari sisi ekonomi,pendidikan, hiburan dan sebagainya. Demikian pula yang harus dilakukan oleh para da'i.agar dakwah tetap berkesinambungan. Penyesuaian kebiasaan baru di masa pandemic dengan optimalisasi kompetensi menggunakan mediamedia yang tersedia baik media cetak, media visual, media audio dan media sosial sebagai sarana menyampaikan materi dakwah.

Aksi personal branding da'i merupakan cara dakwah baru sebagai respon atas perubahan kebiasaan masyarakat di masa pandemi. Da'i harus aktif dan rajin menyajikan materi dakwah di berbagai media baik cetak ,media audio dan media sosial agar masyarakat mengenal sosoknya sebagai pendakwah dan masyarakat senantiasa mendapatkan pengetahuan agama Islam lebih intensif lagi. Da'i juga harus peka dan pandai membaca situasi apa yang sedang trending dimasyarakat dan memberikan 
ulasan ilmu nya menurut ajaran Islam. Sehingga masyarakat tak perlu bingung menyikapi persoalan atau problema kehidupan yang sebagian masyarakat tidak mengetahui kepastian hukum nya baik di AlQuran maupun Al-Hadits Dengan aksi personal branding ini para da'i dituntut harus selalu meng upgrade ilmu agama nya dan kompetensi nya dalam bidang media agar dapat mengakses lebih cepat bila ada tanggapan dari mad'u berupa pertanyaan dan lain nya.

\section{DAFTAR PUSTAKA}

Iswandi Syahputra, 2007, Komunikasi Profetik: Konsep Dan Pendekatan Bandung: Refika Offset,

Enjah AS dan Aliyah, 2009,Dasar-dasar Ilmu Dakwah,Bandung : Widya Padjadjaran,

Abdul Azis,1995, Yang Tegar di Jalan Dakwah ,Jakarta: Gaya Media Pratama, 1995

Jalaluddin Rahmat, 1998, Psikologi Komunikasi Bandung: Rosdakarya, 1998

http://indramukhtaroji.blogspot.com/2014/11/citradai-dimata-masyarakat.html 


\title{
RELEVANSI DAN REAKTUALISASI PRAKTIKUM AUDIT BERBASIS ONLINE
}

\author{
Muzayyidatul Habibah, M.E. ${ }^{19}$ \\ (IAIN Kudus)

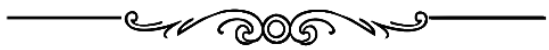

"Output dalam praktikum audit yaitu mahasiswa dapat mengetahui dan memahami dengan baik praktik penyusunan Kertas Kerja Pemeriksaan (KKP), melaksanakan sesuai rencana audit, serta dapat melaksanakan proses audit"

Kegiatan audit merupakan kegiatan pemeriksaan Iterhadap laporan keuangan, sebagaimana dijelaskan bahwa audit adalah pengumpulan data dan evaluasi bukti tentang informasi untuk menentukan dan melaporkan derajat kesesuaian antara informasi dan kriteria yang telah ditetapkan (Arens, 2011). Berdasarkan pengertian tersebut, dapat dipahami secara implisit bahwa kegiatan audit harus dilakukan oleh pihak yang berkompeten dan profesional.

19 Penulis lahir di Pati, 25 Mei 1984, penulis merupakan Dosen IAIN Kudus dalam bidang ilmu Akuntansi Syariah, penulis menyelesaikan gelar Sarjana Ekonomi Jurusan Akuntansi di Universitas Negeri Semarang (2007), sedangkan gelar Magister Ekonomi Konsentrasi Akuntansi Syariah diselesaikan di IAIN Kudus (2017). 
Beberapa faktor dapat mempengaruhi kualitas hasil audit yang dihasilkan oleh auditor, diantaranya yaitu kompetensi, independensi dan motivasi. Sebagai seorang auditor, maka sangat dibutuhkan upaya untuk meningkatkan kompetensi agar dapat menjalankan tugas audit dengan baik. Peningkatan kompetensi auditor dapat didukung dengan mengikuti pelatihan profesional berkelanjutan. Selanjutnya, kemampuan auditor dalam menyusun laporan audit juga dipengaruhi oleh independensi dan motivasi, karena kualitas audit bersumber dari mental audit.(Jefrynaldi, 2021)

Audit atau pemeriksaan laporan keuangan dapat dilakukan oleh pihak internal maupun eksternal, pihak yang melakukan audit tersebut merupakan auditor yang mempunyai sikap independen karena output dari kegiatan audit yaitu berupa opini atas akuntabilitas dari entitas yang diaudit. Auditor eksternal dalam menyampaikan pendapat terkait dengan kewajaran terhadap laporan keuangan, berkaitan dengan materialitas berdasarkan kesesuaian penyusunan laporan keuangan dengan prinsip akuntansi berterima umum (Mulyadi, 2014).

\section{Statistik Akuntan Publik Indonesia}

\begin{tabular}{|c|c|c|c|c|c|c|}
\hline \multicolumn{2}{|c|}{ Anggota IAPI (Per-Oktober 2020) } & \multicolumn{3}{|c|}{$\begin{array}{l}\text { Pertumbuhan Akuntan Publik } \\
\text { dari Tahun ke Tahun }\end{array}$} & \multicolumn{2}{|c|}{$\begin{array}{l}\text { Sebaran Akuntan Publik } \\
\text { Berdasarkan Rentang Umur }\end{array}$} \\
\hline Akuntan Publik & 1429 & Tahun & $\begin{array}{c}\text { Jumlah } \\
\text { Akuntan Publik }\end{array}$ & Penambahan & $\begin{array}{l}\text { Rentang } \\
\text { Umur } \\
\end{array}$ & Jumlah \\
\hline Anggota CPA Non AP & 2466 & 2014 & 999 & - & $<30$ & 18 \\
\hline Anggota Muda & 296 & 2015 & 1.053 & 54 & 30 sd 39 & 219 \\
\hline \multirow{2}{*}{ Anggota Umum - Rekan Non AP } & \multirow{2}{*}{59} & 2016 & 1.093 & 40 & 40 sd 49 & 407 \\
\hline & & 2017 & 1.279 & 186 & 50 s.d 59 & 397 \\
\hline Anggota Umum - Lainnya & 120 & 2018 & 1.358 & 79 & $>59$ & 388 \\
\hline \multirow{2}{*}{ Anggota Kehormatan } & \multirow{2}{*}{7} & 2019 & 1.424 & 66 & \multirow[t]{2}{*}{ Total } & \multirow[t]{2}{*}{1.429} \\
\hline & & 2020 & 1.429 & 5 & & \\
\hline
\end{tabular}

Sumber : Directory |AP|

Gambar 1. Statistik Akuntan Publik Indonesia

148 | Yang Terdepan dalam Menghadapi Pembelajaran Daring 
Potensi bagi para mahasiswa sangat terbuka luas untuk berperan aktif sebagai auditor, sebagaimana data yang dirilis oleh IAPI (Ikatan Akuntan Publik Indonesia), bahwa sebaran akuntan publik yang berusia kurang dari 30 tahun menunjukkan data yang sangat rendah. Maka perlu adanya upaya peningkatan kompetensi audit bagi mahasiswa, yang sesuai dengan kondisi entitas keuangan yang sudah memanfaatkan media berbasis online.

Perkuliahan auditing merupakan mata kuliah prasyarat untuk mengikuti kuliah praktikum audit, agar para mahasiswa mendapatkan pengetahuan yang baik di bidang auditing. Mata kuliah praktikum audit sesuai dengan capaian pembelajaran yang sudah disusun, yaitu untuk memberikan pemahaman kepada mahasiswa terkait dengan praktikum dalam proses audit, termasuk menganalisis kasus yang mungkin akan ditemui di lapangan pada saat melakukan audit. Siklus dalam kegiatan audit dimulai dengan membuat perencanaan audit, pelaksanaan audit dan membuat laporan audit.(RPS, 2020)

Kegiatan pembelajaran pada Perguruan Tinggi merupakan implementasi sistem pengajaran dengan metode mengaktifkan peran mahasiswa, sehingga dosen selaku perantara dapat berperan sebagai pihak yang menyampaikan konsep keilmuan. Jenis metode pembelajaran yang dapat diterapkan yaitu : ceramah, tanya jawab, diskusi, tugas belajar dan resitasi, kerja kelompok, demonstrasi, role playing, problem solving, team teaching, drill, field-trip, recource person, survey masyarakat dan simulasi. Dosen seharusnya menerapkan metode pembelajaran secara kombinasi dan bergantian, agar kelemahan pada salah satu metode dapat teratasi dengan metode lainnya.(Sudjana, 2009) 
Mata kuliah praktikum auditing pada masa sebelum pandemi, tentu saja dapat dilakukan secara intensif melalui tatap muka antara dosen dan mahasiswa, dengan mengerjakan penugasan praktikum auditing sesuai modul yang tercetak dan dikerjakan secara manual. Namun, di tengah masa new normal karena terdampak pandemi covid-19, kegiatan tatap muka tersebut tidak dapat dilakukan, sebagai upaya dalam mengurangi kerumunan dan mendukung upaya pemerintah dalam mengurangi potensi penyebaran covid-19.

Perkuliahan secara online mengharuskan adanya penyesuaian dalam mata kuliah praktikum auditing. Penyampain materi dapat dilakukan oleh dosen pengampu secara virtual melalui zoom atau google meet, sehingga record dapat disetel ulang kembali oleh mahasiswa apabila ada part-part materi audit yang belum dapat dipahami. Dalam hal ini, kuliah virtual memberikan keuntungan yang besar bagi para mahasiswa, karena interaksi dengan dosen dapat tetap dilakukan. Salah satu metode pembelajaran untuk praktikum auditing yang dapat diterapkan yaitu dengan Project Based Learning sesuai dengan Surat Edaran Mendikbud Nomor 4 tahun 2020 (Kemendikbud, 2020), namun karena kondisi new normal yang sangat membatasi aktivitas para mahasiswa dari berbagai daerah, maka metode daring lebih aman dan efektif diterapkan.

Output dalam praktikum audit yaitu mahasiswa dapat mengetahui dan memahami dengan baik praktik penyusunan Kertas Kerja Pemeriksaan (KKP), melaksanakan sesuai rencana audit, serta dapat melaksanakan proses audit sesuai dengan prosedur audit yang sudah direncanakan. 
Materi dalam mata kuliah praktikum audit, (Yusup, 2007) terdiri dari 12 materi, yaitu : 1). Perencanaan pemeriksaan dan sistem akuntansi, 2). Pemeriksaan piutang dagang dan penjualan, 3). Pemeriksaan kas, 4). Pemeriksaan persediaan dan pembelian, 5). Pemeriksaan utang dagang dan utang yang tidak dicatat, 6). Pemeriksaan pencatatan gaji dan utang beban, 7). Pemeriksaan beban dibayar dimuka, 8). Pemeriksaan surat-surat berharga dan investasi, 9). Pemeriksaan aktiva tetap, 10). Pemeriksaan utang wesel dan utang bunga, 11). Pemeriksaan modal saham dan laba ditahan, 12). Penyelesaian pemeriksaan

Berkas pengerjaan mahasiswa pada mata kuliah praktikum audit, dapat dikerjakan melalui excel file yang dikirimkan melalui V-Class pada aplikasi Smurt yang sudah dikembangkan oleh pihak kampus yang terdiri dari tiga bagian, yaitu Kertas Kerja Pemeriksaan (KKP), Laporan Hasil Pemeriksaan (LHP) dan Konfirmasi Hutang Piutang.

Kertas Kerja Pemeriksaan (KKP) berupa Work Balance Sheet (WBS), Work Profit and Loss (WPL) yang dilengkapi dengan index per akun. Sedangkan Laporan Hasil Pemeriksaan (LHP) merupakan bagian akhir dalam penugasan dalam menyusun hasil audit.

\section{DAFTAR PUSTAKA}

Arens, et al. (2011). Jasa Audit dan Assurance, Alih Bahasa Amir Abdul Jusuf, Buku 1. Salemba Empat.

Jefrynaldi, H. (2021). Pengaruh Kompetensi, Indepensi, dan Motivasi Auditor Terhadap Kualitas Audit Internal (Studi Empiris pada Badan Usaha Milik Swasta dan Badan Usaha Milik Negara di Kota Padang). Jurnal Eksplorasi Akuntansi, Volume 3, 233-247. 
Kemendikbud, R. (2020). Surat Edaran Nomor 4 Tahun 2020 Tentang Pelaksanaan Kebijakan Pendidikan Dalam Masa Darurat Panyebaran Coronavirus Disease (Covid-19). https://pusdiklat.kemdikbud.go.id/surat-edaranmendikbud-no-4-tahun-2020-tentangpelaksanaan-kebijakan-pendidikan-dalam-masadarurat-penyebaran-corona-virus-disease-covid1 -

9/\#: :text=Sawangan\%2C\%20Pusdiklat\%E2\%8 0\%94\%20Menteri\%20Pendidikan\%20dan,masa $\% 20$ da.

Mulyadi. (2014). Audit 1 (Edisi ke-4). Salemba Empat.

RPS, T. P. (2020). RPS Praktikum Auditing. IAIN Kudus.

Sudjana, N. (2009). Penilaian Hasil Proses Belajar Mengajar. Remaja Rosdakarya.

Yusup, A. H. S. A. K. (2007). Praktikum Auditing. Pusat Penerbitan Akademi Akuntansi YKPN. 


\title{
ANALISIS PEMANFAATAN MODUL PADA PEMBELAJARAN IPA SMP/MTS SEBAGAI ALTERNATIF MEDIA PEMBELAJARAN DI MASA PANDEMI
}

\author{
Nurlia Latipah, M.Pd.Si ${ }^{20}$ \\ (IAIN Bengkulu)

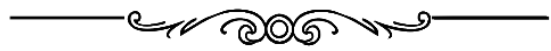

"Keberhasilan modul dalam pembelajaran IPA yang dibuktikan melalui penelitian-penelitian terdahulu telah memberikan gambaran bahwa modul dapat dimanfaatkan dalam kegiatan pembelajaran jarakjauh"

Dembelajaran pada seluruh jenjang pendidikan di Indonesia berganti dari pembelajaran tatap muka menjadi pembelajaran jarak jauh sejak pandemi covid 19 menyerang. Pergantian pola pembelajaran ini merupakan bentuk kebijakan pemerintah untuk mengurangi penyebaran covid 19 di Indonesia. Pengurangan penyebaran covid 19 merupakan hal yang harus dilakukan mengingat dampak negatif yang ditimbulkan oleh covid 19.

${ }^{20}$ Penulis merupakan dosen IAIN Bengkulu pada prodi Tadris IPA yang lahir di Kota Bogor pada tanggal 12 Agustus 1983. Penulis pernah menjadi guru IPA tingakt SMP/MTs sejak tahun 2003. Penulis merupakan alumni S1 Pendidikan Kimia dan S2 Pendidikan IPA pada Universitas Bengkulu. 
Pada pembelajaran tatap muka terdapat interaksi langsung antara guru, peserta didik, materi pelajaran dan lingkungan. Sedangkan pada pembelajaran jarak jauh interaksi langsung antara guru dan peserta didik menjadi sangat kurang. Hal ini berarti pembelajaran jarak jauh menuntut kemandirian siswa dalam memahami materi pelajaran sesuai kurikulum. Menurut Oka dalam Lasmiyati dan Harta (2014) belajar mandiri merupakan belajar aktif dan partisipatif tanpa terikat dengan kehadiran guru dan pertemuan tatap muka di kelas. Belajar mandiri bertujuan untuk mengembangkan diri masing-masing siswa. Untuk itu diperlukan media pembelajaran yang dapat membantu siswa dalam menumbuhkan kemandirian dalam belajar. Salah satu media pembelajaran yang dapat digunakan dalam pembelajaran jarak jauh adalah modul.

Kemandirian siswa melalui pembelajaran dengan modul dapat dicapai karena modul memuat tujuan pembelajaran yang dapat mengarahkan siswa untuk mencapai tujuan pembelajaran, desain modul yang menarik mampu meningkatkan motivasi belajar siswa, modul bersifat flexible sehingga dapat dipelajari oleh seluruh siswa dengan kecepatan belajar berbeda, dan modul juga memberi kesempatan siswa untuk menemukan kelemahan diri melalui evaluasi yang diberikan (Lasmiyati dan Harta, 2014).

Menurut peraturan Menteri Pendidikan Nasional Nomor 22 Tahun 2006 mata pelajaran Ilmu Pengetahuan Alam (IPA) bertujuan agar siswa memperoleh kompetensi dasar IPA serta membudayakan berfikir ilmiah secara mandiri, kreatif, dan kritis. Oleh karena itu pembelajaran IPA pada siswa SMP dengan menggunakan modul diharapkan mampu mewujudkan kemandirian siswa sesuai tujuan 
pembelajaran IPA yang diamanatkan pada peraturan tersebut.

Penelitian Rosa (2015) menunjukkan bahwa modul IPA berbasis keterampilan proses sains dengan ekperimen-eksperimen sederhana yang dikembangkan dapat membantu siswa untuk dapat belajar mandiri, Selain itu modul yang dikembangkan juga mampu meningkatkan kemampuan kognitif siswa dan meningkatkan keterampilan proses sains siswa. Selain itu eksperimen-eksperimen sederhana yang dilakukan siswa secara mandiri sesuai petunjuk modul dapat meningkatkan rangsangan motivasi dan rasa ingin tahu siswa.

Penelitian Sakti dkk (2020) tentang implementasi modul IPA berbasis Etnosains masyarakat Bengkulu materi pengukuran melalui discovery learning untuk meningkatkan kemampuan berfikir kritis mahasiswa menunjukkan bahwa modul sebagai bahan yang dikembangkan dengan mengintegrasikan pengetahuan tentang lingkungan sekitar dengan konsep ilmu dapat meningkatkan kemampuan berfikir kritis mahasiswa. Kegiatan belajar dengan memanfaatkan modul etnosains menjadi daya tarik tersendiri bagi mahasiswa terhadap pembelajaran.

Penelitian Latipah dkk (2017) juga menyebutkan bahwa modul yang dikembangkan dari hasil penelitian mampu meningkatkan kemampuan kognitif mahasiswa yang ditandai dengan meningkatnya hasil belajar mahasiswa setelah menggunakan modul. Modul yang dikembangkan dari hasil penelitian memotivasi mahasiswa dalam belajar karena selain aplikatif, modul ini juga mengenalkan mahasiswa secara dekat dengan alat alat laboratorium yang tidak dapat diakses oleh mereka. Selain itu modul ini juga mampu mengenalkan 
praktikum-praktikum yang tidak dapat dilakukan oleh mahasiswa.

Keberhasilan modul dalam pembelajaran IPA yang dibuktikan melalui penelitian-penelitian terdahulu telah memberikan gambaran bahwa modul dapat dimanfaatkan dalam kegiatan pembelajaran jarak jauh. Kemandirian yang dituntut dalam pembelajaran menggunakan modul menjadi benang merah untuk membangun interaksi antara guru, siswa, materi pelajaran, dan lingkungan. Untuk dapat mewujudkan kemandirian dalam belajar, tentu saja modul perlu didesain sedemikian rupa sehingga mampu mengajak siswa untuk dapat belajar secara mandiri. Keterbatasan alat bantu kegiatan belajar di rumah dalam pembelajaran jarak jauh tentu menjadi tantangan tersendiri bagi guru dalam mengembangkan modul. Namun hal itu tentu saja sebanding dengan hasil yang akan didapat nantinya. Untuk dapat meningkatkan keterampilan sains siswa melalui modul di rumah, guru tentu saja harus menyiapkan praktikum-praktikum sederhana yang dapat dilakukan dengan menggunakan alat dan bahan sederhana yang ada di rumah. Sementara untuk praktikum yang memerlukan alat dan bahan yang tidak bisa disediakan di rumah, maka guru dapat memadukan modul dengan video. Kombinasi ini nantinya akan menghasilkan modul elektronik seperti penelitian yang dilakukan oleh Limatahu dkk (2017) yang menyebutkan bahwa penggunaan video praktikum yang dipadukan dengan modul elektronik menunjukkan interpretasi tinggi terhadap keterampilan proses siswa. Pada saat ini video praktikum selain dapat dibuat sendiri oleh guru, juga dapat diambil dari youtube maupun laboratorium virtual seperti animasi phet atau flash (Latipah, 2020). 
Penelitian Asmuri dkk (2019) menunjukkan bahwa susunan modul IPA Terpadu berbasis SETS antara lain judul modul, petunjuk umum, materi, dan evaluasi semester. Judul modul dapat dibuat sesuai dengan analisis kebutuhan, petunjuk umum dapat berperan sebagai bagian pendahuluan yang memberikan gambaran tentang cara penggunaan modul dan mendeskripsikan isi modul secara keseluruhan. Sedangkan materi berisi kegiatan pembelajaran yang disusun berdasarkan pada pembelajaran inkuiri terbimbing. Untuk evaluasi berisi soal, kunci jawaban, glosarium, dan daftar pustaka. Penelitian ini juga menyebutkan bahwa buku pegangan yang dimiliki siswa memiliki beberapa kelemahan diantaranya menggunakan bahasa yang sulit dipahami, tidak mengaplikasikan contoh kehidupan sekitar, dan gambar yang kurang menarik. Kekurangan pada buku pegangan siswa inilah yang menjadi dasar perlunya mengembangkan modul.

Penelitian terdahulu telah membuktikan bahwa, selain mampu mengembangkan kemandirian siswa dalam belajar, modul juga mampu meningkatkan kemampuan kognitif siswa, meningkatkan kemampuan berfikir kritis, mengenalkan siswa kepada alat-alat praktikum yang tidak dapat diakses, mengenalkan siswa tentang praktikum yang tidak dapat dilakukan langsung, dan meningkatkan keterampilan sains siswa. Hal ini tentu saja dapat menjadi motivasi guru untuk menjadikan modul sebagai media pembelajaran di masa pandemi ini.

Pembuatan modul sebagai media pembelajaran merupakan bagian untuk mengasah kompetensi professional guru di masa pandemi ini. Seperti yang diungkapkan Latipah (2021) bahwa pada masa daring guru dapat mempersiapkan media pembelajaran yang 
dapat diskses dengan mudah oleh siswa, membuat video pembelajaran yang dapat diakses pada kanal youtube, membuat LKPD baik online maupun offline, serta membuat evaluasi pembelajaran untuk mengukur kemampuan siswa secara objektif baik secara online maupun offline.

Secara umum, modul sebagai media pembelajaran dapat dijadikan sebagai media pembelajaran alternatif untuk kegiatan pembelajaran daring. Modul dapat dikembangkan secara online maupun offline. Modul sebaiknya berisi kegiatan-kegiatan belajar yang dapat dilakukan secara mandiri oleh siswa di rumah dalam rangka meningkatkan kemampuan kognitif maupun psikomotor siswa. Tampilan modul, kajian materi, dan langkah-langkah belajar yang ditampilkan dalam modul menjadi daya tarik tersendiri bagi siswa, sehingga pengembangan modul sebaiknya memperhatikan halhal tersebut agar modul dapat membantu guru dalam penyampaian materi pelajaran sesuai kurikulum.

\section{DAFTAR PUSTAKA}

Asmuri, dkk. 2019. Pengembangan Modul IPA Terpadu SMP/MTs Kelas VIII Berbasis SETS untuk Meningkatkan Kemampuan Berfikir Kritis Siswa pada Tema Makanan dan Kesehatan Tubuh. SPEKTRA: Jurnal Kajian Pendidikan Sains Volume 5 Nomor 1.

Lasmiyati, Harta. I. 2014. Pengembangan Modul Pembelajaran untuk Meningkatkan Pemahaman Konsep dan MInat SMP. Jurnal Pythagoras Volume 9 Nomor 2.

Latipah, dkk. 2017. Produksi Biofuel dari Limbah CPO dengan Katalis Berbasis Titanium Oksida dan Implementasinya pada Pembelajaran Kimia. 
PENDIPA:Jurnal Pendidikan sains-Universitas Bengkulu volume 1 Nomor 1.

Latipah, Nurlia. 2020. Pelatihan Pembelajaran Online bagi Guru IPA di Era Covid-19. Dalam Adaptasi Kebiasaan Baru Masyarakat Indonesia pada Era Pandemi Covid 19:Tinjauan Berbagai Disiplin Ilmu. Hal 21-26. Akademia Pustaka. Tulungagung.

Latipah, Nurlia. 2021. Upaya Peningkatan Kompetensi Mahasiswa Tadris IPA dalam Konsep Merdeka Belajar pada Masa Pandemi Covid-19. Dalam waktunya Merdeka Belajar. Hal 9-16. Akademia Pustaka. Tulungagung.

Limatahu, dkk. Pengaruh Video Praktikum dengan Modul Elektronik Terhadap Keterampilan Proses Pada Materi Stoikiometri Siswa Kelas X SMAN 2 Tidore Kepulauan. Jurnal Pendidikan Kimia (JPKim) Volume 9 Nomor 1.

Rosa, Octavia, Friska. 2015. Pengembangan Modul Pembelajaran IPA SMP pada Materi Tekanan Berbasis Keterampilan Proses Sains. Jurnal pendidikan Fisika Universitas Muhammadiyah Metro. Volume III Nomor 1.

Sakti dkk. 2020. Implementasi Modul IPA Berbasis Etnosains Masyarakat Bengkulu Materi Pengukuran Melalui Discovery Learning untuk Meningkatkan Kemampuan Berfikir Kritis Mahasiswa. Jurnal Kumparan Fisika Volume 3 Nomor 3. 
160 | Yang Terdepan dalam Menghadapi Pembelajaran Daring 


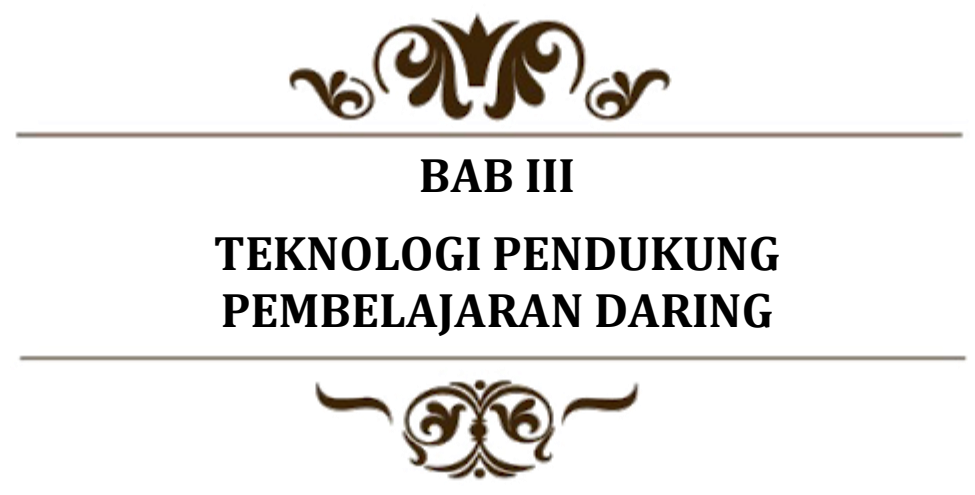

Yang Terdepan dalam Menghadapi Pembelajaran Daring | $16 \mathbf{1}$ 
162 | Yang Terdepan dalam Menghadapi Pembelajaran Daring 


\title{
ADAPTASI VIRTUAL BLENDED APPLICATION UNTUK OPTIMALISASI EFEKTIFITAS KULIAH DARING DI MASA PANDEMI COVID 19
}

\author{
Dr. Nurika Khalila Daulay, M.A. ${ }^{21}$ \\ (UIN Sumatera Utara)

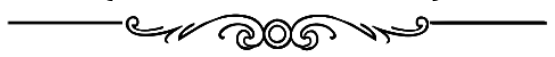

"Untuk efektifitas perkuliahan daring, dosen sendiri menerapkan beberapa aplikasi dalam aktivitas perkuliahan. Dosen menyebutnya sebagai Virtual Blended Application"

\begin{abstract}
i awal diberlakukannya sistem perkuliahan daring di sekitar pertengahan April 2020 yang lalu dikarenakan semakin meluasnya wabah Covid 19 membuat kampus mengeluarkan kebijakan untuk Kuliah dari Rumah (KDR) bagi mahasiswa dan Work from Home (WFH) bagi dosen. Situasi yang masih abnormal kala itu membuat dosen agak mengalami

${ }^{21}$ Penulis lahir di Surabaya, 20 Juni 1977, penulis merupakan Dosen UIN Sumatera Utara-Medan dalam bidang Manajemen Pendidikan, penulis memperoleh gelar Sarjana di IAIN SU Medan Jurusan Tadris Biologi (1999), gelar Magister diperoleh di UIN Syarif Hidayatullah Jakarta Program Studi Pendidikan Islam Konsentrasi Manajemen Pendidikan Islam (2002), dan gelar Doktor Administrasi Pendidikan diselesaikan di Universitas Pendidikan Indonesia-Bandung (2012).
\end{abstract}


kebingungan tentang pola yang mesti diterapkan dalam proses perkuliahan terhadap mahasiswanya, disebabkan dosen maupun mahasiswa sebagian besar belum pernah (bahkan tidak pernah) menggunakan berbagai aplikasi meeting seperti Zoom meet dan Google meet sebagai pengganti tatap muka yang sebelumnya dapat dilakukan secara langsung (off line) di kelas.

Hal ini menjadi hal baru sekaligus pengalaman baru bagi dosen dan mahasiswa di dunia perkuliahan kala itu. Berbagai persoalan, seperti gagap teknologi (gaptek), gagap cara mengoperasikan aplikasi, kekuatiran mahasiswa tentang hacker yang akan menjebol keamanan android dan mobile banking, biaya penyediaan kuota, sampai ke soal jaringan yang tidak mendukung di beberapa daerah/kampong asal mahasiswa, dan beberapa problem lainnya, sehingga hanya pada dua pertemuan di awal perkuliahan saja dilaksanakan pertemuan tatap muka secara daring, selebihnya dengan terpaksa penulis mengikuti kemauan mahasiswa untuk memadakan dengan menggunakan salah satu aplikasi medsos (Whatsapp) karena mahasiswa masih kekeuh dengan kekuatiran-kekuatiran itu tadi.

Proses mengubah mindset (sebagian besar) mahasiswa ternyata membutuhkan waktu satu semester untuk membuat sistem daring ini menjadi sesuatu tuntutan pembiasaan baru dan jaminan secure atas data-data penting mahasiswa di masing-masing android mereka. Saat ini, pada beberapa kelas yang penulis masuki saat ditanyakan tentang respon mereka untuk lebih memilih luring atau daring, apa jawaban mahasiswa ? mereka menjawab "Daring saja bu". Ya, hanya dalam kurang dari enam bulan, mahasiswa sudah lebih menyukai dan nyaman dengan perkuliahan secara daring dibanding secara luring. Itu faktanya. 
Tentu saja ini bukan tanpa sebab, pastilah ada beberapa alasan yang mendukung perubahan sikap mahasiswa, penerimaan mahasiswa, untuk menjadikan aktivitas perkuliahan daring sebagai opsi pelaksanaan proses perkuliahan yang mesti diikuti oleh mahasiswa, meski dosen-dosen yang mengajar di kelas mereka tentu saja menerapkan pendekatan dan strategi yang bervariasi, berbeda antara satu dengan lainnya terutama dalam pemilihan aplikasi sebagai media perkuliahan daring untuk matakuliah yang diampu. Setelah melakukan proses pembiasaan selama satu semester, mahasiswa menjadi lebih lancar dan mudah menggunakan beberapa aplikasi yang disarankan dosen.

Selain itu, berbagai layanan kemudahan untuk memperoleh kuota internet melalui program pemerintah juga turut andil membuat mahasiswa merasa tidak lagi terlalu terbebani oleh biaya kuota yang sebelumnya terasa sangat mahal dan memberatkan mahasiswa terutama saat pengguanan aplikasi Zoom meeting maupun Google meet untuk keperluan tatap muka perkuliahan secara daring yang memang membutuhkan kuota lebih. Mahasiswa merasa nyaman juga dikarenakan dengan sistem daring ini mahasiswa dapat mengoperasikan aplikasi virtual tersebut dari manapun bahkan saat mereka berada di daerah/tempat tinggal mereka yang berada jauh di luar kota Medan tanpa harus hadir ke lokasi kampus UIN SU Medan, meski kendala jaringan terkadang masih menjadi problem di beberapa daerah tertentu, namun secara umum, mahasiswa dapat mengakses jaringan internet secara baik dan relatif lancar.

Sama halnya dengan mahasiswa, dosen (baca: penulis) pun dengan semakin berjalannya waktu, semakin merasakan skill ber-daring semakin baik, meski belum bisa dibilang expert, penulis mulai bisa 
mengkolaborasikan beberapa strategi yang digunakan dengan berbagai media sosial online yang tersedia, sehingga mempermudah juga dalam melaksanakan proses perkuliahan. Prinsipnya bahwa antara dosen dan mahasiswa harus telah menyepakati, sama-sama tahu dan paham, tentang hak dan kewajiban mereka sejak pertemuan awal perkuliahan. Masing-masing mahasiswa bertanggungjawab dalam setiap kegiatan perkuliahan dan dalam pemenuhan tugas-tugas perkuliahan, disiplin untuk selalu ontime dalam setiap mengawali perkuliahan daring selayaknya perkuliahan tersebut dilakukan secara luring.

Untuk efektifitas perkuliahan daring, dosen sendiri menerapkan beberapa aplikasi dalam aktivitas perkuliahan. Dosen menyebutnya sebagai Virtual Blended Application (aplikasi campuran/gabungan virtual) dengan menggunakan beberapa aplikasi virtual dimana satu aplikasi dengan aplikasi lainnya saling melengkapi, seperti dijelaskan berikut ini.

$>$ Zoom meeting atau Google meet, untuk fasilitasi tatap muka langsung secara Online antara dosen dengan mahasiswa, dan mendukung kegiatan diskusi mahasiswa.

> Whatsapp Group (waG) untuk fasilitasi beberapa keperluan di luar tatap muka online, via Chat, Voice notes, share Video presentasi atau share link, serta untuk mengisi Absensi kehadiran perkuliahan.

> Google Classroom, untuk fasilitasi pengumpulan file tugas-tugas perkuliahan secara individu, seperti paper dan mini research, pengumpulan file UTS, pengumpulan file UAS, dan juga dapat share bahan/materi perkuliahan berupa Sillabus dan RPS matakuliah, file e-Book dan e-Journal. Google Classroom mempermudah kerja dosen agar secara langsung dapat mencek dan mengoreksi tugas yang 
dikirim oleh mahasiswa, dan mengembalikannya ke mahasiswa jika diperlukan untuk perbaikan. Google Classroom juga mengefisienkan kerja dosen untuk memberi pembobotan nilai secara langsung dari setiap tugas individu mahasiswa. Untuk bisa mengakses aplikasi GC ini setiap user harus sudah memiliki akun gmail terlebih dahulu sebagai syarat untuk bisa join ke Google Classroom.

> Youtube (share link Youtube), untuk fasilitasi keperluan meng-unggah file video presentasi, file pelaporan tugas Video film documenter, dan untuk browsing video materi-materi perkuliahan yang dapat diakses via Youtube, dengan menampilkan (Link) video terkait ke Zoom meeting/Google meet, dan atau membagikan Link video materi terkait ke Whatsapp Group dan atau ke Google Classroom.

Pertemuan tatap muka perkuliahan dengan menggunakan aplikasi Zoom meeting atau Google meet (tergantung pilihan mahasiswa), meski dalam implementasinya beberapa kelas masih menggunakan durasi waktu Zoom meeting yang terbatas (40 menit) dan akan diperpanjang kembali dengan membuat link schedule baru, kecuali jika menggunakan Zoom yang versi upgrade dan berbayar sehingga durasi time-nya tidak terbatas, atau bisa juga dengan menggunakan fasilitas kampus. Berbeda dengan Google meet yang durasi waktunya tidak terbatas tanpa perlu mengupgrade. Dosen (Penulis) akan menjadi Host di awal pertemuan perkuliahan saja, pertemuan selanjutnya mahasiswa (via Kosma atau Sekma) diarahkan untuk membuat Link meeting perkuliahan kelas-nya sendiri dan dishare ke Whatsapp Grup (waG) kelas agar dosen dan seluruh mahasiswa dapat bergabung ke kelas supaya bisa tatap muka secara virtual. Dosen akan memfoto mahasiswa (participants) yang hadir setiap 
pertemuan atau bisa juga melalui Google form sebagai acuan untuk mengisi kehadiran mahasiswa mengikuti perkuliahan daring ke dalam Sistem aplikasi Daftar Hadir Online mahasiswa (DAHLIA) yang dapat diakses melalui https://dahlia.uinsu.ac.id/.

Pada setiap pertemuan perkuliahan daring, durasi perkuliahan tetap disesuaikan dengan durasi waktu sebagaimana perkuliahan luring, saat memulai dan mengakhiri perkuliahan di setiap pertemuan mestilah sesuai jadwal. Jangan sampai dosen menggunakan atau menambah waktu perkuliahan di luar dari schedule yang telah ditentukan, karena akan berdampak pada tidak efektifnya proses perkuliahan sehingga menimbulkan kejenuhan yang bisa menjadi alasan bagi mahasiswa untuk malas melaksanakan perkuliahan daring dan juga penyelesaian tugas perkuliahan. Selain itu juga akan terjadi bentrok jadwal perkuliahan mahasiswa antara satu matakuliah dengan matakuliah lainnya yang justru akan mengorbankan dan merugikan mahasiswa sendiri di satu sisi, sementara di sisi lain akan menyulitkan dosen mengatur ritme tugas mengajarnya secara optimal.

\section{DAFTAR PUSTAKA}

Amalia, Andina. Sa'adah, Nurus. 2020. Dampak Pandemi Covid-19 terhadap Kegiatan Belajar Mengajar di Indonesia. Jurnal Psikologi. Desember 2020; 13 (2): 212-225.

Https://Doi.Org/10.35760/Psi.2020.V13i2.3572.

Bali, Muhammad Mushfi El Iq. Musrifah. 2020. The Problems of Application of Online Learning in the Affective and Psychomotor Domains During the Covid-19 Pandemic. Jurnal Pendidikan Agama 
Islam. Desember 2020; 17 (2): 137-154. DOI: https://doi.org/10.14421/jpai.2020.172-03.

Bilfaqih, Yusuf. Qomarudin, M. Nur. 2015. Esensi Pengembangan Pembelajaran Daring Panduan Berstandar Pengembangan Pembelajaran Daring untuk Pendidikan dan Pelatihan. Ed.1, Cet. 1-Yogyakarta: Deepublish.

Sulisworo, Dwi. dkk. 2020. Praktik Pembelajaran Online Era Covid-19. Yogyakarta: CV. Markumi.

Sumantri, Agus. dkk. 2020. Booklet Pembelajaran Daring. Jakarta: Direktorat Jenderal Pendidikan Tinggi Kemdikbud RI. 
170 | Yang Terdepan dalam Menghadapi Pembelajaran Daring 


\title{
LEARNING MANAGEMENT SYSTEM (LMS): APLIKASI PEMBELAJARAN VIRTUAL DI MASA PANDEMI COVID-19
}

\author{
Santiana, S.S., M.Pd. ${ }^{22}$ \\ (Universitas Siliwangi)

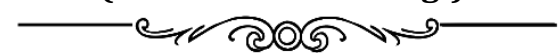

"Learning Management System (LMS) merupakan aplikasi perangkat lunak yang dapat mengelola, mendokumentasikan, melacak, melaporkan, mengotomatiskan, dan menyampaikan suatu kegiatan berupa kursus pendidikan, pelatihan, serta program pengembangan pembelajaran"

$\mathrm{T}$ idak pernah ada yang menyangka ataupun menduga bahwa masa pandemi Covid-19 akan berlangsung lama. Sejak bulan Februari 2020 virus Covid-19 terus mewabah dan semakin meluas hampir diseluruh wilayah di Indonesia. Berbagai macam cara dan upaya telah dilaksanakan oleh pemerintah untuk menekan laju

22 Penulis lahir di Tasikmalaya, Jawa Barat. Dia merupakan Dosen Universitas Siliwangi, Jurusan Pendidikan Bahasa Inggris. Penulis menyelesaikan gelar Sarjana di STBA YAPARI-ABA Bandung, Jurusan Bahasa Inggris (2001), sedangkan gelar Magister Pendidikan diselesaikan di Universitas Pendidikan Indonesia (UPI), Bandung, Program Studi Pendidikan Bahasa Inggris (2009). Selain sebagai Dosen, saat ini Penulis dipercaya menjadi Kepala Pusat Kerja Sama Universitas Siliwangi. 
merebaknya virus tersebut. Program vaksinasi Covid-19 pun telah dilakukan, namun belum berhasil mengatasi laju penyebaran Virus Covid-19.

Seiring dengan keadaan yang belum membaik, hal ini berdampak kepada semua sektor, termasuk sektor Pendidikan. Para pendidik (guru ataupun dosen) baik sektor formal maupun non-formal dipaksa harus memutar otak agar pembelajaran tetap dapat dilaksanakan dengan baik. Para pendidik mencari alternatif untuk menyampaikan materi secara online (daring) kepada peserta didiknya. Kegiatan pembelajaran virtual pun menjadi alternatif yang terbaik yang dapat dilakukan oleh guru ataupun dosen. Teknis pembelajaran virtual ini dapat dilaksanakan secara synchronous atau real-time maupun secara asynchronous atau tanpa interaksi real-time (Santiana, 2021). Aplikasi yang dapat digunakan untuk pembelajaran secara virtual atau online dikenal dengan sebutan Learning Management System (disingkat LMS).

Learning Management System (LMS) merupakan aplikasi perangkat lunak yang dapat mengelola, mendokumentasikan, melacak, melaporkan, mengotomatiskan, dan menyampaikan suatu kegiatan berupa kursus pendidikan, pelatihan, serta program pengembangan pembelajaran. Beberapa ahli berpendapat bahwa LMS adalah "software that allows an organization to host, deliver, and track employee or customer training. It is typically used for employee onboarding" (Gray, 2019). Selanjutnya, Burton (2020) mengatakan bahwa, "a Learning Management System (LMS), is an e-learning tool that helps trainers create, upload, manage, distribute, and track their online training initiatives in one place." Sementara itu Mardinger (2020) menjelaskan bahwa, "learning management system is a software-based or Software as 
a Service (SaaS) platform that facilitates the management, delivery, and measurement of an organization's corporate e-learning programs. Dapat disimpulkan bahwa LMS merupakan suatu aplikasi perangkat lunak yang dapat membantu seseorang menyampaikan materi, mendistribusikan, mengatur, serta membuat konten pelatihan ataupun pembelajaran kepada berbagai audiens yang dapat diakses secara online dimanapun dan kapanpun.

Terdapat beberapa sistem aplikasi pembelajaran/ Learning Management System (LMS) yang dapat digunakan untuk mendukung proses belajar mengajar secara virtual, diantaranya: LMS Canvas, Berikut ini merupakan penjelasan secara singkat mengenai LMS Canvas.

\section{Canvas by Instructure}

Canvas by Instructure atau lebih popular disebut Canvas adalah sistem manajemen pembelajaran yang menggunakan platform online atau dilakukan secara virtual. Canvas

CANVAS didirikan pada tahun 2008 oleh Josh Coates dan pertama kali dirilis pada tahun 2011 (Aldiab, A. et.al, 2019). Dengan menggunakan Canvas ini pembelajaran virtual dapat dilakukan oleh Guru/Dosen dan siswa. Kegiatan yang dapat dilakukan pada Canvas diantaranya adalah untuk mengakses dan mengelola materi pembelajaran kursus/mata pelajaran/mata kuliah secara virtual, mengomunikasikan tentang pengembangan keterampilan, serta mengukur prestasi belajar siswa. Fitur Canvas meliputi pembuatan kursus dan alat manajemen yang dapat disesuaikan, diantaranya: menyediakan akses mudah untuk memerikan dan melihat nilai, tugas, diskusi, jadwal kursus, tutorial video, analitik perpesanan, aplikasi pendidikan, laporan tugas, kolaborasi individu dan grup, 
tugas peninjauan sejawat, dan masih banyak yang lainnya.

Manfaat menggunakan Canvas antara lain: 1) Grading Control. Dengan menggunakan Canvas baik Guru/Dosen maupun siswa dapat mengontrol penilaian. Tersedianya fitur tersebut memungkinkan siswa untuk mengetahui posisi dalam kursus/mata pelajaran/mata kuliah yang diikuti karena mereka dapat mengakses nilai secara langsung melalui fitur Grades. Sedangkan Guru ataupun Dosen dapat membuat penilaian tugas menjadi lebih cepat sehingga bisa menghemat waktu. 2) Automated Tasks. Dengan adanya fitur Assignments Guru/Dosen dapat membuat menu tugas secara otomatis sehingga Guru/Dosen dapat mengeset waktu untuk pengumpulan tugas, sedangkan Siswa menerima pesan yang dikirim Canvas melalui email sebagai pengingat tenggat waktu pengumpulan tugas agar siswa tidak melewatkan tugas yang diberikan Guru/Dosen. 3) Cloud-Based Course Content yaitu Canvas dapat mengatur dan menyimpan semua materi di satu lokasi yang terpusat dengan aman dan siswa dapat mengakses materi tersebut kapanpun dan dimanapun.

Canvas dapat dijadikan sebagai media untuk berkomunikasi. Dalam fitur Canvas dimungkinkan adanya interaksi antara Guru/Dosen dengan siswa. Pola komunikasi yang dilakukan pada Canvas dapat dilakuakn dengan berbagai macam cara, diantaranya:

1. Conferences/Konferensi. Penggunaan fitur konferensi memudahkan Guru/Dosen untuk melakukan pembelajaran secara synchronous atau real-time kepada seluruh siswa yang mengambil kursus/mata pelajaran/mata kuliah yang ditawarkan. Pada kegiatan konferensi Guru/Dosen dapat menyuguhkan audio, video, aplikasi demo, 
berbagi slide presentasi ataupun berbagi sumber secara real-time.

2. Discussion/Diskusi. Pada Canvas disediakan fitur diskusi yang memungkinkan adanya interaksi antara Guru/Dosen dengan siswa maupun antara siswa dengan siswa. Guru/Dosen dapat melontarkan isu yang akan dibahas atau didiskusikan, sementara siswa dapat berkontribusi pada topik yang didiskusikan. Kegiatan ini bisa dijadikan sebagai acuan keaktifan siswa dalam proses pembelajaran yang bisa dimasukan ke dalam poin penilaian ataupun dijadikan sebagai catatan saja. Selain itu forum diskusi inipun bisa dijadikan sebagai media untuk melontarkan pertanyaan terkait materi yang belum dipahami siswa.

3. Chat/Obrolan. Dengan adanya fitur chat memungkinkan Guru/Dosen untuk mengadakan percakapan langsung dengan siswa serta menjawab pertanyaan yang dilontarkan mereka.

4. Inbox/Kotak Masuk. Pesan ataupun percakapan yang ditulis di-inbox dapat membantu Guru/Dosen berkomunikasi dengan siswa di semua kursus yang dibuat. Guru/Dosen tidak perlu mengelola alamat email siswa untuk dapat berkomunikasi namun bisa dilakukan secara langusung pada fitur tersebut.

5. Collaborative Spaces and Groups/ Ruang dan Grup Kolaboratif. Canvas menyediakan ruang virtual bagi siswa untuk mengerjakan dokumen dan berdiskusi dengan sesama siswa secara kolaboratif. Kegiatan ini dapat berlangsung secara real-time artinya semua perubahan yang dilakukan ataupun yang dibuat oleh setiap penggunanya dapat langsung terlihat oleh semua orang yang mengakses Canvas. 
Kegiatan ini dapat menumbuhkan self-learning dan collaborative learning pada siswa.

6. Assignment Feedback/umpan balik tugas. Seorang Guru/Dosen biasanya suka memerikan tugas kepada siswa. Hal ini dimaksudkan sebagai upaya untuk mengetahui pemahaman siswa terhadap materi yang telah diberikan/diajarkan. Guru/Dosen dapat dengan mudah memerikan umpan balik tugas yang diberikan sehingga siswa mengetahui secara pasti apa yang diharapkan.

7. Notifications/Pemberitahuan. Guru/Dosen maupun siswa bisa mendapatkan pemberitahuan dan peringatan melalui email, pesan teks, atau media sosial mengenai kegiatan yang akan dilakukan pada Canvas.

8. Announcements/Pengumuman. Dengan adanya fitur announcements ini semua siswa mendapatkan informasi penting terkait kursus/mata pelajaran/mata kuliah yang diambil, dapat diperbarui secara instan, tanpa harus melalui akun email Guru/Dosen ataupun aplikasi lain di luar Canvas.

9. To-do-List/daftar yang harus dilakukan. Siswa yang mengikuti pembelajaran kerap kali lupa akan sesuatu yang harus mereka lakukan di Canvas sebagai konsekuensi mengambil kursus/mata pelajaran/mata kuliah. Pada tampilan menu utama, di beranda kursus, terdapat daftar yang harus dilakukan, hal ini dapat mengingatkan siswa tentang kegiatan yang harus dilakukan pada waktu mendatang.

10.Calender/Kalender. Pada Canvas terdapat menu navigasi global yang menampilkan fitur calender. Fitur ini difungsikan sebagai navigasi kegiatan yang 
berkaitan dengan kursus/mata pelajaran/mata kuliah yang diambil oleh siswa. Pada fitur calender dapat berisi tentang catatan waktu semua kegiatan yang harus dikerjakan sehingga dapat membantu siswa untuk mengingat serta dapat mencegah ketinggalan dalam menyelesaikan tugas dan sebagai pengingat untuk Guru/Dosen untuk melakukan kegiatan penilaian.

Selain berbagai benefit yang telah disampaikan sebelumnya, Canvas pun memiliki keunggulan lainnya yaitu Interface Canvas yang sangat customizable dan intuitive, dengan menggabungkan semua elemen yang biasanya terdapat pada kelas virtual, diantaranya: Navigation (Navigasi). Pilihan menu dan navigasi dapat disesuaikan dengan kebutuhan pengguna. Hal ini membantu pengguna untuk menavigasi berdasarkan hal yang dianggap paling penting. Selanjutnya dashboard (dasbor). Penggunaan halaman dasbor dapat dengan cepat merangkum tugas, pengumuman, dan informasi relevan lainnya di seluruh kursus/mata pelajaran/mata kuliah yang ditawarkan/diambil. Selain itu, dalam Canvas menyediakan fitur User Profile (Profil Pengguna) yang dapat diisi sesuai dengan biodata pemakainya sehingga baik Guru/Dosen maupun siswa dapat lebih mengenal satu sama lain dengan melihat pada fitur tersebut. Lebih lanjut dari segi aksesibilitas pun Canvas dapat diandalkan karena dapat diakses dimana saja dan kapan saja sepanjang ada koneksi internet.

Itulah sekilas penjelasan mengenai Canvas yang dapat dijadikan sebagai acuan bagi Guru/Dosen dalam menentukan Learning Management System (LMS) terbaik yang akan digunakan dalam pembelajaran virtual/online (daring). 


\section{DAFTAR PUSTAKA}

Burton Colin. (2020). What is a Learning Management System? Feature, Examples, and Best Practices. Diakses pada 9 Mei, 2021, dari https://www.thinkific.com/blog/what-is-lms.

Gray Sherry. (2019). Learning Management Systems Explained. Diakses pada 9 Mei, 2021, dari https://www.thebalancesmb.com/learningmanagement-system-4768684.

Mardinger Reanna. (2020). What is LMS? Diakses pada 16 Mei 2021, dari https://www.docebo.com/learningnetwork/blog/what-is-learning managementsystem/.

Santiana. (2021). Integrasi Keilmuan dalam Menyongsong Merdeka Belajar. Canvas: Media Pembelajaran Efektif Pada Masa Covid-19. Tulungagung: Akademia Pustaka. 


\title{
PEMANFAATAN YOUTUBE UNTUK PENILAIAN KETERAMPILAN PADA MAHASISWA PGMI DI ERA PEMBELAJARAN PANDEMI
}

\author{
Rohmah Ivantri, M.Pd. ${ }^{23}$ \\ (UIN Sayyid Ali Rahmatullah Tulungagung)

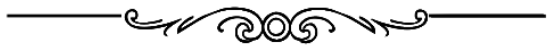

"Perkembangan youtube semakin pesat dalam dunia pendidikan karena youtube mempunyai peran penting dalam mengembangkan sumber daya manusia yang berkualitas"

\begin{abstract}
Tak asing lagi terdengar di telinga kita tentang media 1 youtube dalam dunia pendidikan. Hal ini dikarenakan youtube adalah salah satu situs web untuk berbagi video kreatif dimana para pengguna dapat memuat, menonton, dan berbagi secara gratis. Di situs youtube banyak terdapat video pembelajaran yang dapat dijadikan sebagai media pembelajaran baik oleh umum maupun dalam lembaga pendidikan.
\end{abstract}

${ }^{23}$ Penulis lahir di Tulungagung, 01 Oktober 1990, penulis merupakan Dosen PGMI IAIN Tulungagung dalam bidang ilmu Pendidikan Dasar Islam. 
Dengan youtube pula memudahkan seorang pendidik maupun peserta didik untuk memperoleh pengetahuan. Pendidik juga tidak hanya sekedar memanfaatkan media youtube tersebut, bisa pula membuat konten sendiri untuk menyajikan materi. Dengan membuat konten sendiri juga akan memudahkan pendidik dalam menyampaikan materi sesuai dengan karakteristik anak didiknya. Mengakses youtube juga dirasa mudah sekali, sebab anak kecil pun sekarang sudah bisa akses dengan cepat media tersebut. Sehingga banyak para pendidik memanfaatkan youtube sebagai salah satu media pembelajaran yang dirasa sangat efektif dan efisien.

Saat ini perkembangan youtube semakin pesat dalam dunia pendidikan karena youtube mempunyai peran penting dalam mengembangkan sumber daya manusia yang berkualitas. Youtube juga dapat membantu mengembangkan potensi pada diri mahasiswa baik secara spiritual, kepribadian, pengendalian diri, kepribadian, kecerdasan, akhlak mulia, serta ketrampilan yang diperlukan dirinya, masyarakat, bangsa dan negara (Haryadi Mujianto: 2019). Hal ini didukung pula adanya tantangan pembelajaran jarak jauh yang dialami oleh peserta didik dan pendidik. Dalam pemanfaatan media youtube pendidik berperan penting sebagai komunikator dan fasilitator (Agus Suardika dkk). Sebagai komunikator pendidik berperan menghubungkan antara materi dengan peserta didik melalui media yang tepat untuk pembelajaran daring. Dan sebagai fasilitator pendidik memfasilitasi proses pembelajaran daring dengan menyediakan media apa yang tepat untuk pembelajaran daring.

Dalam pembuatan video di youtube perlu adanya skill yang harus dimiliki pendidik. Untuk skill itu perlu adanya pelatihan sederhana membuat video yang bagus 
dan jernih (Abdulloh: 2019). Hal ini harus diketahui oleh mahasiswa PGMI karena mereka akan menjadi pendidik nantinya yang siap dengan tantangan teknologi yang semakin canggih. Maka dari itu mahasiswa harus terbiasa dengan membuat konten atau video pembelajaran sendiri. Karena selain akan mendukung skillnya dalam mengajar di era tantangan pembelajaran pandemi tetapi juga menjadi poin plus untuk pengembangan pembelajaran di era teknologi yang canggih.

Dalam mata kuliah tertentu yang menuntut adanya penilaian ketrampilan atau praktik, dosen sebagai pendidik harus bisa menentukan media apa yang tepat untuk bisa mengukur sejauh mana kemampuan mahasiswa dalam hal praktik setelah mendapatkan materi tentang teori. Karena pada mahasiswa PGMI perlu adanya skill pendidik yang dibangun dalam jiwanya tidak hanya sekedar teori. Mereka harus terampil dalam mengajar dalam berbagai situasi dan kondis serta dituntut pula pandai dalam hal menentukan sumber dan media apa yang tepat dalam mengajar nantinya. Hal ini harus dibiasakan sejak di masa kuliah agar mereka ketika lulus menjadi sarjana sudah terampil dalam mengajar dan terampil dalam administrasi.

Di era pandemi ini untuk mengetahui sejauh mana mahasiswa memahami teori dan terampil dalam mengajar, media youtube yang murah dan mudah di aksses ini bisa menjadi salah satu solusi dalam penilaian ketrampilan. Karena dalam penilaian ketrampilan itu penggunaan media yang tepat juga menjadi faktor utama dalam mengukur sejauh mana kemampuan mahasiswa dalam memahami teori. Dalam penilaian ketrampilan ada 3 jenis, yaitu penilaian praktik, penilaian produk dan penilaian proyek. Media yotube 
ini termasuk dalam penilaian produk, sebab di sini mahasiswa dituntut membuat konten atau video pembelajaran yang menarik dalam praktik mengajar. Dalam pembuatan konten tersebut mahasiswa juga dituntut terampil membawa atau menggunakan media pembelajaran yang menarik dan mempermudah mahasiswa dalam menyampaikan materi.

Pembuatan konten atau video pembelajaran oleh mahasiswa memiliki prasyarat harus dishare dicannel youtube dan bisa diakses oleh semua orang. Terkadang ada mahasiswa yang malu sehingga mereka memprivasi konten yang telah mereka buat, seharusnya video yang telah mereka buat bisa bermanfaat bagi orang lain. Dosen sebagai bisa mendidik bisa melihat tayangan youtube dari mahasiswa kapan pun dan dimana pun, sehingga jika seorang dosen masih repot dalam hal tertentu bisa melihat ketika waktu longgar.

Penilaian mahasiswa tidak hanya dapat diambil dari pandangan atau tolak ukur dosen itu sendiri tetapi bisa pula dengan melihat komentar atau like, dan subscribe dari teman-teman semua. Dosen tetep memiliki peranan penting dalam penilaian pada video yang telah dibuat mahasiswa, karena tolak ukur dosen tidak hanya sekedar melihat kemenarikan ataupun kreatifitas mahasiswa tetapi juga dilihat bagaimana attitude dalam mengajar, menyampaikan materi, membuka dan menutup pelajaran.

Dalam penilaian keterampilan berbasis produk, mahasiswa juga dituntut untuk lebih luwes ketika mempraktikkan mengajar, sehingga penilaian keterampilan dalam skill mengajar dapat terukur secara maksimal. Tetapi sebelum adanya penilaian keterampilan ini dosen meminta RPP dari mahasiswa agar mengetahui jalannya pembelajaran yang akan dibuat konten oleh mahasiswa. Jadi kesesuaian antara 
RPP dan video pembelajaran tersebut dapat saling sinkron atau sesuai. Jadi jalannya video pembelajaran dapat terarah dan lebih mudah dalam pengukuran skill mengajar dan administrasi.

Penilaian keterampilan berbasis produk ini diharapkan mahasiswa bisa mengeksplor bakat dalam dirinya. Tidak hanya sekedar skill mengajar, tetapi juga nilai seni yang tertanam dalam jiwanya bisa tersalurkan. Sebab mengajar itu tidak hanya sekedar menyampaiakan materi, harus bisa pula menarik peserta didik untuk fokus dalam mengikuti pembelajaran. Sehingga di era pandemi ini mahasiswa PGMI harus sekreatif mungkin menemukan solusi mengajar apa yang tepat dalam pembelajaran. Dimana dalam pembealajaran tersebut dapat membuat peserta didik tertarik dan semangat dalam mengikuti pembelajaran yang berlangsung meskipun jarak jauh.

Pembelajaran jarak jauh di era pandemi ini merupakan tantangan bagi pendidik baik guru maupun dosen dalam hal pengambilan penilaian yang dapat mengukur kemampuan yang mereka miliki. Terutama bagi mahasiswa PGMI keterampilan mengajar itu penting, jadi untuk mengungkap seberapa jauh kepemahaman ataupun kemampuan mahasiswa tersebut penilaian keterampilan berbasis produk ini bisa menjadi solusi terbaik. Selain mereka dapat mengeksplore bakat mengajarnya, mereka juga dapat membuat konten sekreatif mungkin yang dapat menarik penonton terutama siswa MI/SD untuk menyaksikan. Jadi pemanfaatan youtube untuk penilaian keterampilan dapat menghiasi channel youtube untuk video pembelajaran bagi anak MI/SD. 


\section{DAFTAR PUSTAKA}

Abdulloh Abdulloh, dkk. Penggunaan Media Sosial (Youtube) Sebagai Media Inovatif dalam Pembelajaran di Madrasah Gresik. Vol.5 No.1 Juni 2019.

Agus Suradika, dkk., Penggunaan Youtube sebagai Media Pembelajaran Jarak Jauh pada Kelas III Sekolah Dasar Islam An - Nizomiyah. Prosiding Seminar Nasional Penelitian LPPM UMJ.

Mujianto, Haryadi. Pemanfaatan Youtube sebagai Media Ajar dalam Meningkatkan Minat dan Motivasi Belaja. Jurnal Komunikasi Hasil Pemikiran dan Penelitian Vol. 5; No. 1; Tahun 2019. 


\title{
PEMBELAJARAN DARING BERBASIS ZOOM CLOUD MEETING PADA MASA PANDEMIK COVID-19
}

\author{
Ns. Rina Delfina, S.Kep, M.Kep 24 \\ (Universitas Bengkulu)

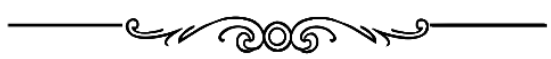

"Salah satu metode pembelajaran yang dapat dilakukan adalah dengan metode daring. Salah satu aplikasi yang bisa digunakan untuk pembelajaran daring selama masa pandemik adalah zoom meeting"

$\mathrm{M}$ asa pandemik COVID-19 menimbulkan berbagai masalah dalam berbagai tatanan kehidupan masyarakat, salah satunya masalah pendidikan. Dimana

24 Rina Delfina lahir di Solok, 17 September 1973, Penulis menyelesaikan jenjang pendidikan S1 pada Program Studi Ilmu Keperawatan Fakultas Kedokteran Universitas Andalas Padang pada tahun 2003, jenjang pendidikan S2 diselesaikan penulis di Fakultas Ilmu Keperawatan Univernitas Andalas Padang tahun 2015. Kegiatan utama penulis adalah mengajar di prodi D3 Keperawatan Universitas Bengkulu, melakukan penelitian dan pengabdian masyarakat. Beberapa bidang mata ajar yang diampu penulis antara lain Manajemen Keperawatan, Keperawatan Maternitas, Keperawatan anak dan Konsep Dasar Keperawatan. Korespondensi dengan penulis dapat dialamatkan melalui Prodi D3 Keperawatan Universitas Bengkulu. E-mail dapat dialamatkan ke rdelfina@unib.ac.id 
pada masa ini mahasiswa tidak memungkin untuk mengikuti proses pembelajaran langsung karena sosial distancing yang diterapkan untuk memutuskan mata rantai penyebaran virus corona. Agar proses pembelajaran tetap berjalan, seorang dosen harus mampu mencari metode alternatif dalam penyampaian materi pembelajaran, sehingga pencapaian proses belajar mengajar tetap tercapai walaupun dalam kondisi seperti saat ini (Covid-19).

Salah satu metode pembelajaran yang dapat dilakukan adalah dengan metode daring. Salah satu aplikasi yang bisa digunakan untuk pembelajaran daring selama masa pandemik adalah zoom meeting. Dalam menunjang pembelajaran daring terdapat beberapa tool yang dapat digunakan untuk menunjang kegiatan tersebut. Zoom meeting merupakan aplikasi yang digunakan untuk kegiatan seperti halnya video conference, sehingga dapat digunakan untuk kegiatan synchronous e-learning, dimana antara pelajar dan pengajar dalam satu waktu yang sama namun berbeda tempat.

\section{A. Aplikasi Zoom Meeting}

Aplikasi zoom merupakan layanan berupa softwere yang bisa digunakan untuk belajar maupun rapat atau konferensi. Zoom saat ini banyak digunakan sebagai media komunikasi dan media pembelajaran. Pada masa pandemik ini yang tidak memungkinkan dilakukannya pembelajaran langsung di dalam kelas, aplikasi zoom ini dapat digunakan untuk penyampaian materi baik teori maupun praktek. Aplikasi ini membuat telecommuting jarak jauh lebih praktis, efisien dan disertai banyak fitur- fitur yang membuat pertemuan online lebih nyaman. Aplikasi Zoom dapat digunakan dosen sebagai media pembelajaran kepada mahasiswa yang dilakukan 
dari rumah. Aplikasi ini banyak digunakan sebagai media komunikasi jarak jauh.

Zoom memberikan kemudahan bebas biaya atau gratis bagi penggunanya yang mendownload aplikasi ini melalui laptop maupun smartphone, sehingga mahasiswa dengan mudah dapat mengaplikasikan zoom dimanapun dia berada.

\section{B. Pembelajaran Daring di Zaman Pandemik.}

Pembelajaran e-learning melalui aplikasi zoom bisa dilakukan untuk pembelajaran teori dan praktek. Belajar melalui online (online learning) juga disebut belajar melalui elektronik (electronic learning), sekarang lebih dikenal dengan sebutan e-learning (Smaldino, Russell, Heinich, Molenda, 2005). Sumbersumber yang digunakan untuk mengakses meliputi situs-situs web (websites), internets, intranets, CDROMs, dan DVDs. Di samping menyajikan pembelajaran, belajar secara online ini dapat memantau kinerja dosen dan melaporkan kemajuan mahasiswa (Kurtanto,2017).

Selama masa pandemik COVID-19 ini proses pembelajaran dapat dilakukan di rumah mahasiswa dapat diarahkan untuk mencari pemecahan masalah yang berhubungan mata kuliah yang sedang mereka ikuti. Solusinya bisa dari sisi kesehatan dan perawatan. Solusi yang ditawarkan harus memiliki landasan teori yang kuat dan bukan sekedar ide liar; di sinilah letak mahasiwa akan belajar mencari tahu. Solusi tersebut harus dikerjakan secara kelompok walaupun tidak bertemu tatap muka. Solusi yang ditawarkan harus dipresentasikan dalam bentuk video dan diunggah ke media sosial seperti Youtube, Facebook, Linkedin, Line, ataupun yang lain (Charismiadji. A, 2020).

Hal yang harus dipersiapkan dosen dalam pembelajaran daring melalui aplikasi zoom ini adalah: 
1. Mempersiapkan Rancangan Pembelajaran Daring

a. Membuat Deskripsi Mata Kuliah yang terdiri dari: 1) Nama MK (+ Kode + SKS). 2) Sapaan, foto dosen pengampu dan email. 3) Deskripsi singkat mata kuliah/topik. d. Kegunaan mata kuliah/topik bagi mahasiswa (mungkin sebagai syarat kerja, atau untuk pengembangan ilmu, atau sebagai landasan mata kuliah lain). 4) Capaian pembelajaran. 5) Peta urutan bahan ajar (bab/modul/babak) dan jadwal/waktu untuk beban belajar. 6) Petunjuk mempelajari bahan ajar.

b. Babak (setiap Bab/Modul/sesi tatap muka)

1) Pendahuluan: a. Sapaan ma mahasiswa. b. Gambaran umum materi. c. Relevansi dengan pengetahuan mahasiswa. d. Capaian pembelajaran.

2) Penyajian: a. Uraian bahan ajar(study notes, ppt, video, simulasi, links, dll). b. Contoh Latihan. c. Rangkuman. d. Forum Diskusi

3) Penutup: a. Tes/ Soal/ Tugas/ assignment. b. Umpan balik untuk menilai diri sendiri. c. Tindak lanjut (saran). d. Refleksi. e. Pengumuman materi perkuliahan baik teori maupun praktek. Materi dapat disiapkan dalam bentuk power point atau modul. 2 . Dosen membuat link dan jadwal perkuliah zoom, mahasiswa bisa masuk melalui link yang sudah dibuat dosen dan waktu yang sudah ditentukan. 3. Saat pembelajaran berlangsung dosen dapat mempresentasikan materi secara online dengan menggunakan fitur share screen. Untuk pembelajaran praktek mahasiswa dapat melihat langsung 
melalui zoom setiap prosedur tindakan yang dilakukan dosen atau bisa jika dengan menampilkan video yang sudah disiapkan dosen.

c. Evaluasi Mandiri

d. Daftar Pustaka

e. Senarai/glosari

Dengan mempersiapkan rancangan pembelajaran secara lengkap, akan mempermudah dalam pelaksanaan proses pembelajaran daring.

Tips dalam membuat rancangan pembelajaran :

1) Daftar Kelengkapan MK Daring

2) Identifikasi mk: kode, sks, info technology compatibility, foto dosen, email, hp, waktu belajar yang diperlukan

3) Bahasa: komunikatif, menyapa mhs, bukan bahasa gaul, tetap bahasa ilmiah, konsistensi istilah

4) Gambar dan sumber belajar lain: etika copyright dll

5) Video: talking head harus melihat mahasiswa, tidak stiff neck, dll.

6) Bahan tidak hanya pdf atau ppt saja, harus multimedia, harus link ke sumber lain.

7) Interaksi: difokuskan pada keterampilan produktif/ responsif (response, manipulation, co-construction.

Selanjutnya yang harus dipersiapkan dosen adalah Acuan penilaian Mutu (Konten, Proses, Asesmen, Sistem) yang terdiri dari : 
1) Rencana Pembelajaran (Component)

2) Materi (Content)

3) Metode \& Strategi Interaksi (Proses)

4) Asesmen dan Evaluasi

5) Teknology (Sistem)

6) SDM (tambahan dari educating online forum $\mathrm{KL})$

Setelah mempersiapkan rancangan pembelajaran dosen dapat melaksanakan proses secara daring sesuai dengan jadwal yang sudah dibuat.

\section{Evaluasi dari dosen}

Penggunaan aplikasi zoom meeting sangat mudah untuk digunakan sebagai media pembelajaran daring. Aplikasi ini dapat memberikan interaksi langsung antara mahasiswa dan dosen. Dengan metode ini mahasiswa dapat memberikan langsung umpan balik dalam proses pembelajaran. Mahasiswa juga dapat melakukan diskusi antara mahasiswa dalam menyelesaikan tugas yang diberikan. Mahasiswa melaksanakan sesuai dengan tahapan komunikasi terapeutik. Atau metode praktek dapat juga dibuat mahasiswa melalui aplikasi lain seperti vidio youtube, mahasiswa dapat mempresentasikannya secara online pada saat dilakukan pembelajaran melalui zoom meeting.

\section{Evaluasi dari mahasiswa}

Penggunaan aplikasi ini sangat membantu mahasiswa dalam menerima materi dari dosenKemudian adanya penggunaan kuota yang bertambah sehingga membebani mereka dalam membeli pulsa. Hal ini juga akan memepengaruhi kehadiran mahasiswa dalam perkuliahan daring. 
Pengaruh sinyal yang lemah juga menimbulkan masalah untuk bisa masuk dalam meeting, sehingga waktu mulai perkuliahan tertunda.

Dari hasil evaluasi yang dilakukan pada mahasiswa, mereka mengungkapkan dapat memahami materi yang disampaikan melalui aplikasi zoom ini.

\section{DAFTAR PUSTAKA}

Alessi, S.M \& Trollip, S.R. (2001). Multimedia for Learning: Methods and Development. (3rd Ed). Boston MA: Allyn and Bacon, Inc.

Arsyad, A. (2007). Media Pembelajaran. Jakarta: PT Raja Grafindo Persada.

Blended Learning: How to Integrate Online \& Traditional Learning. (t.thn.).

Chaeruman, U. (2017). Model Desain Sistem Pembelajaran Blended ; Panduan Merancang Mata Kuliah Daring SPADA Indonesia. Jakarta: Direktorat Jendral Pembelajaran Dan Kemahasiswaan, Kementrian Riset, Teknologi dan Pendidikan Tinggi.

Charismiadji.A. (2020, April 01). Mengelola Pembelajaran Daring Yang Efektif. Mengelola Pembelajaran Daring Yang Efektif.

Gary R. Morrison, Steven M. Ross, Jerrold E. Kemp. (2001). Designing Effective. Wiley.

Heinich, D. Russell, Molenda., \& E Smaldino. (2005). Instructionla Tecnology and Media for Learning. New Jersey, Columbus, Ohio ; Pearson Merrill Prentice Hall: Upper Saddle River.

Kurtanto. (2017).

KEEFEKTIFAN MODEL PEMBELAJARAN DARING. Journal Indonesian 
Language Education and Literature Vol. 3, No. 1, 99-109.

Mayer, E. (2009). Multimedia Learning Prinsip-Prinsip dan Aplikasi. Yogyakarta: Pustaka Belajar.

Simarmata J, Sari D.C, Wahyudin D, Mufarizuddin, Hasibuan M. S. (2019). Inovasi Pendidikan Lewat Transformasi Digital.

Thorne, K. (2003). Blended Learning:How to Integrate Online \& Traditional Learning). London \& Sterling: VA:Kogan Page Limited. 


\title{
IMPLEMENTASI PENGGUNAAN APLIKASI VIDEO CONVERENCE CISCO WEBEX DALAM PELAKSANAAN PRAKTEK KOMUNITAS II PADA MASA PANDEMIC COVID-19
}

\author{
Siti Nurjannah, SKM.,M.Kes ${ }^{25}$ \\ (Akademi Keperawatan Sri Bunga Tanjung Dumai)

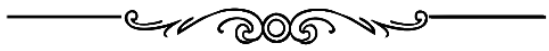

"Webex adalah sebuah aplikasi online yang dikembangkan oleh perusahaan cisco yang membuat para pengguna dapat saling berkolabrasi melalui gambar, video, dan suara dari manapun secara mudah"

\section{A. Aplikasi video converence cisco webex}

\section{Definisi webex}

Webex adalah sebuah aplikasi online yang dikembangkan oleh perusahaan cisco yang

${ }^{25}$ Siti Nurjannah, SKM.,M.Kes lahir pada tanggal 06 Desember 1990 di Senama Nenek, Kabupaten Kampar, RIAU. Menyelesaikan Studi S2 di STIKes Hangtuah Pekanbaru tahun 2014. Penulis adalah seorang Dosen di akademi keperawatan Sri Bunga Tanjung, Kota Dumai sejak Tahun 2016. Saat ini penulis sedang menjabat sebagai Direktur Akademi Keperawatan Sri Bunga Tanjung. Tinggal di JL. Raya Lubuk Gaung Rt 003 Kelurahan Lubuk Gaung Kecamatan Sungai Sembilan Kota Dumai, RIAU. No. HP : 081378802810 
membuat para pengguna dapat saling berkolabrasi melalui gambar, video, dan suara dari manapun secara mudah. Webex mengkombinasikan komunikasi lewat telepon (suara) dengan tampilan di layar computer (gambar). Sehingga dengan fitur webex ini kita dapat melakukan pertemuan secara online tanpa batas tempat, dimannapun. Tidak ada perangkat keras yang harus dibeli, maupun perangkat lunak yang harus diunduh, dengan aplikasi ini, baik perusahaan maupun pengguna perorangan bias mengurangi biaya operasional dan membuat pekerjaan lebih efisien.

\section{Kelebihan dan kelemahan penggunaan webex}

Webex ini sangat baik digunakan untuk melihat dan mengikuti secara langsung pembelajaran dari jarak jauh yang bias dilakukan oleh instruktur ( dosen) dan peserta didik (mahasiswa/i) dari tempat yang berbeda dimanapun, mereka bias berdiskusi secara online dan bertatap muka langsung.

a. Kelebihan

1) Bias saling terhubung melalui video

Simulasi pertemuan tatap muka antar pengguna/ mahasiswa dengan dosen pembimbing yang berbeda lokasi dengan fitur multi-point video.

2) Berbagi komputer meja, dokumen, dan aplikasi

Memudahkan pengguna untuk mengendalikan computer meja atau desktop pengguna lain dan juga sebaliknya, mengkolaborasikan isi data, mengaturnya di layar computer tanpa harus mengunggah isi data terlebih dahulu.

3) Multimedia

Memudahkan presentasi melalui fitur-fitur Microsoft powerpoint, audio serta video. 


\section{4) Audio dan Voip yang terintegrasi}

Pengguna dapat memilih toll (pulsa) atau toll-free (bebas pulsa) untuk berinteraksi audio, ataupun menggunakan voice over IPm (teknologi yang memungkinkan perccakapan jarak jauh melali media internet dimana data suara diubah menjadi kode digital dan dialirkan melalui jaringan yang mengirimkan paket-paket data, dan bukan lewat sirkuit analog telepon biasa yang terintegrasi di computer)

b. Kelemahan

1) Belum bias di pakai di semua jenis handphone

2) Sangat tergantung pada jaringan/ signal

3) Konten pada mobile phone tidak selengkap pada penggunaan laptop atau computer

4) Bisa dimanfaatkan untuk merekam hal -hal yang bersifat negative

\section{B. Pelaksanaan praktek komunitas II}

Praktek Klinik Keperawatan Komunitas II dilaksanakan dilahan praktik di wilayah binaan masyarakat termasuk individu, keluarga, kelompok berisiko tinggi. Puskesmas, posyandu, sekolah melalui Asuhan Keperawatan komunitas dari masalah sederhana sampai masalah yang komplek secara tuntas dan komprehensif baik bersifat promotif, preventif, dengan tidak mengabaikan aspek kuratif dan rehabilitative sesuai batas kewenangan, tanggung jawab dan kemampuan berlandaskan etika keperawatan professional.

Keperawatan komunitas II merupakan salah satu mata ajar klinik yang di praktekan di lapangan oleh mahasiswa/I akademi keperawatan sri bunga tanjung 
setelah mahasiswa menyelesaikan tahap mata kuliah komunitas I di Akademik. Dalam pelaksanaannya, mata ajar keperawatan komunitas terdiri dari 3 sks, sehingga lama mahasiswa di lapangan 3 Minggu. Mata ajar keperawatan komunitas pada tahap Praktek Keperawatan Komunitas II adalah menampilkan pemberian pelayanan dan asuhan keperawatan dalam pencegahan primer, sekunder, dan tertier terhadap komunitas dengan masalah kesehatan yang bersifat actual, risiko, dan potensial/wellness.Aplikasi pengetahuan mengenai konsep keperawatan komunitas dalam menyelesaikan masalah keperawatan yang muncul sebagai akibat dari tidak terpenuhinya kebutuhan dasar komunitas yang dapat diatasi atau ditanggulangi dengan intervensi keperawatan komunitas.

Namun demikian Pada tanggal 30 Januari 2020, WHO mengumumkan wabah sebuah coronavirus baru (COVID-19) sebagai kedaruratan kesehatan masyarakat yang meresahkan dunia. Di garis terdepan, tenaga kesehatan memberikan pelayanan yang dibutuhkan pasien suspek dan terkonfirmasi COVID-19, yang seringkali dijalankan dalam keadaan menantang. WHO menyadari tugas dan tanggung jawab besar ini serta pentingya melindungi tenaga fasilitas layanan kesehatan. Sedangkan Indonesia diawali dengan temuan penderita penyakit korona virus 2019 (COVID-19) pada 2 Maret 2020. Hingga 20 April 2020, telah terkonfirmasi 6.575 kasus positif COVID-19 dengan 686 kasus sembuh dan 582 kasus meninggal.

Berdasarkan pertimbangan diatas maka Akademi Keperawatan Sri Bunga Tanjung Dumai memutuskan komunitas II yang seyogyanya dilaksanakan dilapangan Wilayah Kerja Puskesmas Jayamukti di RT 02 Kelurahan Tanjung Palas Kecamatan Dumai Timur tidak dapat 
dilanjutkan lagi, namun demikian pelaksanaannya dapat dialihkan di wilayah rumah mahasiswa masing-masing (comunity from home). Dalam menghadapi pandemi covid-19 ini perawat adalah salah satu lembaga kesehatan yang memiliki peran aktif dalam upaya meningkatkan derajat kesehatan masyarakat begitu juga halnya dengan mahasiswa sebagai lapis kedua dari tim kesehatan. Sehingga mahasiswa keperawatan mempunyai peran dalam promosi kesehatan.

Mahasiswa perawat harus dapat mempromosikan kesehatan dengan menyesuaikan bahasa dan budaya yang ada agar dapat diterima oleh kelompok masyarakat. Selain itu perawat perlu memahami model dan teori konseptual mengenai keperawatan keluarga, keperawatan komunitas, dan ilmu sosial keluarga dan komunitas. Hal tersebut bertujuan untuk mengembangkan pengetahuan dan pemahaman masyarakat mengenai kesehatan keluarga dan komunitas. Sehingga mahasiswa keperawatan dapat menjadi duta pemutusan mata rantai covid-19 di lingkungannya masing-masing

Praktek Keperawatan Komunitas II, pendataan yang sudah dilakukan pada tanggal 16 dan 17 Maret 2020 di Wilayah Kerja Puskesmas Jayamukti di RT 02 Kelurahan Tanjung Palas Kecamatan Dumai Timur tetap dapat dilanjutkan proses asuhan keperawatan komunitas namun dilaksanakan secara daring/online dengan dosen pembimbing masing-masing serta dengan tetap memperhatikan masalah utama yang terjadi pada saat pandemi ini yaitu pemutusan mata rantai penularan covid-19. untuk selanjutnya setiap pertemuan dapat dilaksanakan secara daring/online, hanya saja aplikasi dapat dilaksanakan dilingkungan rumah masing-masing (community from home) 


\section{Implementasi Penggunaan Aplikasi Video}

Converence Cisco Webex Dalam Pelaksanaan Praktek Komunitas II Pada Masa Pandemic Covid-19

Dalam pelaksanaan praktek klinnik komunitas II ada kompetensi yang harus dicapai, antara lain :

1. Melaksanakan Praktek Klinik Keperawatan Komunitas II berdasarkan etika keperawatan

2. Berkomunikasi dengan masyarakat dan tenaga kesehatan secara professional

3. Melakukan pendekatan dengan tokoh masyarakat, petugas kesehatan dan aparat yang terkait

4. Mempunyai komitmen dalam pengembangan keperawatan ke depan dan terhadap tujuan praktek

5. Melakukan kerjasama lintas sektoral dan lintas program

\section{Evaluasi penggunaan aplikasi video converence cisco webex}

1. Evaluasi Oleh Dosen Pengguna Aplikasi

Masa pandemi covid-19 tidak mengurangi tanggungjawab dosen memberikan bimbingan kepada mahasiswa/i yang sedang melakukan praktek komunitas II dikarenakan dapat menggunkan aplikasi video conference cisco webex. Semua proses praktek komunitas II dapat terlaksana, menurut dosen yang mendjadi kendala saat bimbingan praktek komunitas II ini adalah kondisi signal atau jaringan di daerah masingmasing sehingga ada sedikit kendala saat menggunkan video cisco webEx ini, namun tidak kendala yang berarti. 
2. Evaluasi oleh mahasiswa

Sama halnya dengan yang dirasakan oleh dosen pembimbing, kendala saat melaksanakan implementasi praktek komunitas II hanya dikarenakan signal atau jaringan yang kadang hilang timbul, dikarenakan praktek komunitas sudah berjalan saat mendapatkan data di lapangan dan hanya melanjutkan pembimbingan jadi tidak terlalu menjadi kendala dalam pelaksanaan komunitas II ini.

\section{DAFTAR PUSTAKA}

Muryosetyo,

2019.

ONLINE

(https://www.muryosetyo.com/2019/05/penger tian-apa-itu-webex-cisco-dan.html?m=1) diakses pada hari rabu tanggal 27 Mei 2020 pukul 14:51 WIB

https://pauddikmaskaltim.kemdikbud.go.id/wpcontent/uploads/2019/12/Panduan-Webex.pdf diakses pada hari rabu 3 juni 2020 pukul $10: 00$ WIB

Buku Panduan Komunitas II

Buku Akademik Keperawatan Sri Bunga Tanjung, https://diskominfo.dumaikota.go.id/ 
200 | Yang Terdepan dalam Menghadapi Pembelajaran Daring 


\title{
HI TECH HI TOUCH: SENI MENGAJAR DI ERA DIGITAL MENGGUNAKAN BAHASA KASIH SAYANG
}

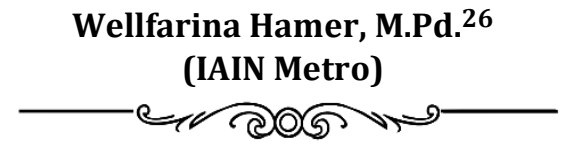

"Bahasa kasih yang dimiliki manusia tidak dapat digantikan oleh kecanggihan tekhnologi manapun sebagai simbol revolusi dan moderenisasi saat ini"

\begin{abstract}
Dendidikan merupakan hal yang sangat menyita perhatian banyak kalangan diera digital saat ini seolah kita dihadapkan pada kemajuan teknologi yang semua bisa dikerjakan secara virtual berbasis $h i$ technologi yang serba cepat serba dinamis, bila kita menengok kembali sejarah tentu kita akan teringat akan revolusi industry yang terjadi di Inggris dimana terjadi perubahan tatanan secara besar- besaran ketika banyak peran manusia yang bisa digantikan oleh mesin dan juga robot, di Negara kita tercinta inipun demikian saat ini
\end{abstract}

${ }^{26}$ Penulis lahir di Tanggamus 18 Februari 1992, saat ini penulis merupakan seorang Dosen di IAIN Metro dalam bidang ilmu pendidikan IPS (Sosial Studies) . Tahun 2013 penulis menyelesaikan pendidikan S1 pada program studi pendidikan ekonomi Universitas Lampung (Unila) dan Tahun 2015 telah menyelesaikan pendidikan S2 pada program studi Magister pendidikan IPS Universitas Lampung (Unila). 
kita ada dimasa digitalisasi dengan satu usapan jari saja kita dapat menjelajahi dunia. Kemajuan tekhnologi saat ini seperti pisau bermata dua disatu sisi dapat memudahkan segalanya namun disisi lain bila kemajuan tekhnologi ini tidak dimaknai dengan baik tentu dapat merusak manusia, contohnya saja dalam aspek pendidikan dimana para siswa dengan mudah dapat memeroleh pengetahuan, pemahaman dan relasi belajar melalui jaringan internet, siswa pun menjadi lebih kreatif membuat konten- konten edukasi menarik yang bisa bermanfaat bagi oranglain, lain ceritanya bila kemajuan ini digunakan siswa yang kecanduan game online yang berdampak pada rendahnya minat belajar siswa, belum lagi pada siswa yang sudah kecanduan pornografi sehingga dapat merusak akal sehat dan pikirannya.

Pendidikan di era digital dan dimasa pandemi saat ini tentu berdampak pula pada banyak aspek. Perubahan proses kegiatan belajar mengajar misalnya, berdampak pada perubahan strategi pembelajaran yang juga akan berpengaruh secara langsung terhadap perilaku belajar siswa yang semula dijalankan melalui kegiatan belajar mengajar dikelas menjadi kegiatan secara e-learning, virtual/ online meeting yang menuntut siswa agar bisa belajar secara mandiri menggunakan berbagai pendekatan yang sesuai agar mampu mengarahkan, memotivasi, dan mengatur dirinya sendiri dalam pembelajaran. Kemandirian belajar siswa diharapkan dapat terbentuk melalui Strategi pembelajaran E-learning namun demikian kondisi ini nampaknya membuat peran guru menjadi kurang nampak terlihat. Dalam keadaan ini guru tetap bertindak sebagai fasilitator yang mengarahkan siswa dalam kegiatan belajar mengajar, pembelajaran secara daring dimasa pandemic ini membuat adanya sekat pemisah yang menjadi jarak antara guru dan peserta 
didik. Dapat dipastikan bahwa sentuhan kasih sayang, cinta yang tulus, atau perhatian tidak terjadi antara guru dan peserta didik. Proses mendidik menjadi sangat gersang karena kemutakhiran tekhnologi tidak mampu mengungkapkan perasaan dan hati nurani dalam menyampaikan pesan pendidikan.

Sekolah harusnya seperti taman yang menyenangkan bagi anak- anak begitulah Ki Hajar Dewantara berpesan, suasana belajar yang nyaman akan terbentuk melaui perangai guru yang mendidik siswa dengan penuh kasih sayang karena sebagaimana yang kita pahami bahwa kasih sayang sebagai basis utama pendidikan, namun istilah ini dirasa semakin dipertanyakan dalam dunia pendidikan modern. Bila kita meninjau dari aspek perkembangan sejarah pendidikan yang berkaitan dengan tujuan utama pendidikan maka sangat jelas tema utama yang muncul adalah kasih sayang atau mendidik siswa dengan akhlak dan karakter yang baik. Para ilmuan klasik telah menyatakan hal tersebut terlebih dahulu seperti Thomas lickona, Montesori dan yang paling utama adalah bagi seorang muslim Rasulullah Muhammad SAW telah memberi tauladan yang baik tentang mendidik anak dengan sentuhan kasih sayang sebagaimana Rasulullah diutus Allah untuk menyebarkan rahmah/ kasih sayang bagi seluruh Alam. Dan Tiadalah Kami mengutusmu, melainkan untuk (menjadi) rahmat bagi semesta Alam. (QS.Al-Anbiya'21107) (Sayang \& Rahmatullah, n.d.)

Pada pembahasan kali ini Saya memaknainya sebagai seni mengajar menggunakan bahasa kasih sayang sebagai ruh seorang guru, sebagaimana yang telah dijelaskan bahwa kasih sayang merupakan basis utama pendidikan. Dasar pendidikan yang dilandaskan pada kasih sayang dimaksudkan adalah bahwa keterhubungan mendidik dan mengajar yang melekat 
pada guru harus bersentuhan langsung dengan pikiran dan perasaan para peserta didik. Pengetahuan, pengalaman, dan keterampilan yang ada pada guru adalah merupakan bagian dari apa dan bagaimana seharusnya yang dilakukan guru. Peserta didik tidak boleh lepas dari perhatian seorang guru terlebih dalam kondisi saat ini yang memang pertemuan langsung antara guru dan siswa sangat dibatasi, mereka sangat butuh motivasi dan pemahaman guru terhadap kesulitan- kesulitannya serta mendampinginya dengan penuh kasih sayang sangat mereka harapkan sehingga siswa tetap dalam pengawasan yang utuh dari seorang guru, iya guru sebutan untuk sosok orangtua kedua siswa yang sangat mereka kagumi.

Fenomena yang muncul dalam pendidikan modern sebagaimana telah diuraikan di atas, memerlukan suatu kesadaran di kalangan pendidik, untuk memberikan perimbangan antara sistem pendidikan modern yang identik dengan kemutakhiran teknologi, dengan kesadaran penuh untuk memberi sentuhan kasih sayang langsung sebagai seni dalam mendidik anak selaku peserta didik. Kesadaran untuk memberikan perimbangan antara teknologi pembelajaran modern dan sentuhan kasih sayang yang memadai, akan memberikan peruntungan ganda bagi para peserta didik. Upaya yang diperlukan adalah mencari keseimbangan antara upaya mencerdaskan anak dengan menggunakan pendekatan-pendekatan mutakhir teknologi namun tetap mendasarkan proses pendidikan dengan sentuhan kasih sayang.

Bahasa kasih yang dimiliki manusia tidak dapat digantikan oleh kecanggihan tekhnologi manapun sebagai simbol revolusi dan moderenisasi saat ini. Perubahan zaman tetap menjadi bagian dari dinamika dengan terus berupaya menyesuaikan diri untuk 
mencerdaskan anak didik sesuai dengan tuntutan zaman. Sisi penting lainnya yang perlu diperhatikan adalah keterlibatan pendidik secara langsung untuk tetap bersama para peserta didik meskipun secara fisik tidak terlihat namun sentuhan bahasa kasihnya bisa jelas dirasakan siswa sehingga baik siswa, orangtua, guru dan semua pemerhati pendidikan bisa melewati dengan baik masa pandemic saat ini dengan segala problematika yang menyertainya.

Berkisah tentang seni mengajar artinya kita akan membahas beberapa hal yang berkenaan dengan pedagogi terutama yang dikaitkan dengan kemampuan guru menggunakan metode dan strategi pengajaran tertentu. Istilah pedagogi berasal dari bahasa latin, yaitu dari kata paeda yang artinya anak, dan gogi yang artinya pendidikan. Dengan demikian untuk memahami pedagogi selalu dikaitkan dengan seni mengajar anak terutama yang berkaitan dengan pemilihan dan penggunaan metode pengajaran tertentu. Artinya strategi atau seni pedagogi yang diterapkan oleh pendidik yang satu tentu berbeda dengan pendidik yang lainnya. Selanjutnya pedagogi kasih sayang, tentu saja yang merupakan seni mendidik anak dengan tetap memberikan sentuhan kasih sayang, dan cinta yang tulus.

Kasih sayang (kindness) berdasarkan karya kiwari atau modern telah dikenal sebagai fondasi dari belajar mengajar yang baik. Ide tentang kasih sayang telah dipertimbangkan penting semenjak Aristoteles beberapa abad yang lalu yang mengkonseptualisasikan kasih sayang sebagai kebajikan dalam agama yang tercantum dalam kitab suci. Sedangkan ide empati secara serius menjadi kajian filosofi aestetika baru pada pertengahan 1980-an yang mengait dengan pedagogy of love. Segera setelah itu, empati diperhitungkan menjadi 
isu yang sangat penting untuk belajar yang bermakna (meaningful learning) selain itu juga sangat perlu meningkatkan kepedulian terhadap peserta didik.(Sayang \& Rahmatullah, n.d.)

Pada bagian ini beberapa hal yang mungkin dapat bersama- sama kita upayakan untuk menjadi guru yang berkualitas, seorang guru yang bukan hanya memiliki pemikiran yang cerdas namun juga memiliki ketulusan, keindahan akhlak serta keikhlasan yang tidak terbatas. Beberapa hal dibawah ini mungkin perlu kita perhatikan agar menjadi pendidik yang berkarakter dan dicintai peserta didik kita.

\section{Mencintai diri sendiri}

Dalam sebuah training motivasi yang pernah saya ikuti, seorang trainer pernah melontarkan pertanyaan kepada peserta untuk menyebutkan tiga orang yang paling di cintai didunia ini? dan hampir semua peserta menyebutkan beberapa diantaranya yang pertama adalah Ibu, Ayah dan pasangan hidup (suami/istri) tidak ada satupun yang menyebutkan diri sendiri sebagai orang pertama yang harus dicintai terlebih dahulu. Padahal kita sendirilah yang harus paham benar siapa diri kita terlebih dahulu, memerhatikan apa yang baik untuk kita, seperti apa karakter kita, apa yang kita suka dan apa yang tidak, maka dengan begitu kita terlebih dahulu harus mencintai diri sendiri terlebih dahulu karena bagaimana kita bisa mencintai oranglain sebelum kita mencintai diri kita sendiri? Bahagiakan diri sendiri terlebih dahulu baru kita bisa membahagiakan orang lain dan dari hal inilah cikal bakal untuk menjadi pribadi yang dicintai peserta didik.

\section{Semangat untuk terus belajar}

Belajar adalah sebuah proses yang sangat panjang dan tidak pernah berakhir, tentu kita pernah mendengar kalimat "tuntutlah ilmu mulai dari buaian 
sampai ke liang lahat" atau pepatah mengatakan "kejarlah ilmu sampai ke negeri Cina" tentu hal ini menggambarkan bahwa proses belajar itu tidak pernah berhenti. Begitupun ketika kita ingin menjadi seorang guru yang bekualitas dan dicintai anak- anak didik tentu kita harus terus belajar bagaimana menjadi pribadi yang baik, berwawasan luas, kreatif, inovatif sehingga kehadiran kita sangat di rindukan mereka.

\section{Membangun karakter yang pancasilais}

Menerapkan karakter yang berlandaskan nilai- nilai pancasila tentu menjadi hal yang sangat baik, berketuhanan yang Maha Esa artinya kita mempercayai bahwa kita tahu benardari mana kita berasal dan akan kemana kita kembali dengan begitu kita akan mengamalkan nilai- nilai kebaikan dari agama yang kita anut. Berkemanusiaan yang adil dan beradab, artinya kita harus berlaku adil dengan sesama manusia tanpa tebang pilih membeda-bedakan orang berdasarkan status sosial dan kepentingan lainnya serta menjaga hubungan yang harmonis dengan sesama. Menjadi pemersatu bangsa, senantiasa bermusyawarah mufakat dalam mengambil keputusan serta pandai menempatkan sesuatu sesuai porsinya dalam bingkai keadilan sosial bagi seluruh rakyat Indonesia.

Beberapa hal diatas bisa bersama- sama kita aplikasikan guna pendidikan Indonesia yang lebih baik, percayalah badai pasti berlalu dan pandemic covid-19 segera hilang agar senyum dan riuh serta tawa renyah guru dan siswa kembali bisa kita rasakan lagi di sekolah, tempat dimana semua asa dirajut dengan sangat indah. 


\section{DAFTAR PUSTAKA}

Sayang, P. K., \& Rahmatullah, A. S. (n.d.). Pendidikan Kasih Sayang Azam Syukur Rahmatullah. (1), 2952.

Rosnawati (2020) pedagogi kasih sayang jurus handal guru millenial.www.kendaripos.co.id 


\title{
PEMBELAJARAN BERBASIS BLENDED LEARNING PADA MASA PANDEMI COVID-19
}

\author{
Kurratul Aini, M.Pd. ${ }^{27}$ \\ (STKIP PGRI Sumenep) \\ 4 खOS W-
}

"Pembelajaran berbasis blended learning adalah proses pembelajaran yang memadukan pembelajaran offline dalam bentuk tatap muka dan pembelajaran online agar pebelajar tetap mampu menerima materi yang disampaikan dan mampu mencapai tujuan pembelajaran"

Dandemi Covid-19 berdampak pada berbagai sendi kehidupan di dunia. Karakteristik penyebaran virus yang tinggi membuat berbagai kebijahan dikeluarkan untuk menekan penyebaran (Herliandry et al., 2020). Mewabahnya pandemi covid-19 diberbagai penjuru dunia "memaksa" perubahan proses pendidikan yang semula dilakukan dengan tatap muka atau konvensional menjadi proses pembelajaran jarak jauh (Makur et al.,

27 Penulis lahir di Sumenep, 25 September 1995. Penulis merupakan Dosen STKIP PGRI Sumenep dalam bidang ilmu pendidikan matematika. Penulis menyelesaikan gelar Sarjana pendidikan matematika di STKIP PGRI Sumenep dan gelar Magister di Universitas Jember pada bidang ilmu yang sama dan menyelesaikan studi tersebut pada tahun 2020. 
2021). Hal ini tak terkecuali negara republik Indonesia yang dipaksa beradaptasi dengan pembelajaran jarak jauh di seluruh area pembelajaran mulai dari tingkatan yang sangat dasar sampai pada tingkat yang lebih tinggi. Pandemi covid-19 menyebabkan seluruh proses pendidikan secara serempak melaksanakan pembelajaran jarak jauh (Sun et al., 2020). Hampir seluruh dunia melaksanakan pembelajaran tanpa tatap muka secara langsung selama pandemi covid-19 (Goldschmidt, 2020).

Pembelajaran jarak jauh menjadi solusi dalam melaksanakan pembelajaran yang tidak dapat dilakukan secara langsung. Pembelajaran jarak jauh dapat dilakukan setiap waktu dilingkungan dimana pengajar dan peserta didik terpisah satu sama lain (Aini, 2021). Pembelajaran jarak jauh memberikan dampak yang besar terhadap seluruh warga sekolah ataupun perguruan tinggi sehingga guru dan dosen dituntut untuk melakukan transformasi pembelajaran yang inovatif dan kreatif mengingat pembelajaran jarak jauh memiliki keterbatasan dalam partisipasi siswa atau mahasiswa (Makur et al., 2021).

Pada tingkat perguruan tinggi, pembelajaran jarak jauh memaksa dosen beradaptasi dengan proses pembelajaran menuntut kompetensi pelaku pendidikan untuk memilih model pembelajaran yang memungkinkan mahasiswa untuk juga mampu beradaptasi dengan proses pembelajaran jarak jauh yang sudah diberlakukan setiap lembaga pendidikan untuk menekan penyebaran covid-19. Seiring berjalannya waktu, untuk daerah yang termasuk zona hijau, dapat melaksanakan pendidikan secara tatap muka dengan senantiasa mencermati waktu yang dibatasi dan penerapan protokol kesehatan yang ketat. Hal ini sebagai bentuk upaya dalam mencegah 
penyebaran covid-19 di sekolah/perguruan tinggi. Kebijakan ini menuntut dosen/guru di wilayah zona hijau menunjukkan inovasi model pembelajaran yang tetap menyesuaikan dengan tujuan pembelajaran yang ingin dicapai (Aini et al., 2020). Model pembelajaran haruslah berorientasi pada keaktifan pebelajar dalam proses pembelajaran jarak jauh yang dilakukan. Pada tingkat perguruan tinggi, model pembelajaran yang dipilih dosen harus memungkinkan mahasiswa untuk tetap aktif (student centered learning) dalam proses pembelajaran jarak jauh. Salah satu model pembelajaran implementasi dari student centered learning adalah pembelajaran berbasis Blended Learning (Kurniawati et al., 2019).

Blended Learning merupakan suatu bentuk pembelajaran yang mengkombinasikan pembelajaran online dan pembelajaran offline (Kurniawati et al., 2019). Selain itu, perkembangan teknologi informasi yang sedemikian pesat sangat sesuai dengan penerapan pembelajaran berbasis Blended Learning (Aslamiyah et al., 2019) karena pada pembelajaran ini proses penyampaian materi atau bahan ajar dilakukan dengan menggabungkan pembelajaran yang berbasis internet, multimedia dan pembelajaran virtual lainnya (Anggraeni et al., 2020). Pembelajaran Blended Learning merupakan pembelajaran yang menggabungkan strategi sinkron dan asinkron sedemikian rupa sehingga pebelajar dapat memiliki pengalaman belajar yang optimal, belajar mandiri untuk mencapai hasil pembelajaran yang diharapkan (Eriani \& Reni, 2020). Blended Learning menawarkan efektifitas pembelajaran yang lebih baik dan menyenangkan, serta efisien dalam meningkatkan kemampuan di lingkungan belajar yang beragam (Abdullah, 2018). 
Blended Learning tidak dilakukan sepenuhnya secara daring, hanya melengkapi proses pembelajaran yang belum tersampaikan di dalam kelas atau tatap muka langsung (Diana et al., 2020). Lebih lanjut Dwiyogo (Dwiyogo, 2018) menyebutkan bahwa pembelajaran berbasis blended learning memadukan kegiatan tatap muka, serta pembelajaran berbasis komputer. Hal ini sejalan dengan pernyataan Anggraeni, dkk (Anggraeni et al., 2020) bahwa blended learning adalah perpaduan kelas tradisional dengan pembelajaran kelas modern berbasis internet. Berdasarkan pendapat pendapat tersebut disimpulkan bahwa pembelajaran berbasis Blended Learning adalah proses pembelajaran yang mengkombinasikan pembelajaran offline dan pembelajaran online agar pebelajar tetap mampu menerima materi yang diberikan. Blended Learning yang diterapkan di lembaga pendidikan pada masa pandemi covid-19 dapat memanfaatkan kemajuan teknologi agar tetap menghasilkan output pendidikan yang sesuai dengan tuntutan zaman.

Komponen Blended Learning terdiri dari:

a. Independent learning atau online learning

Menurut Siti \& Hasbullah (Istiqomah \& Anggun, 2019) independent learning diartikan sebagai bentuk proses pembelajaran mandiri dengan mengakses berbagai materi online melalui internet.

b. Pembelajaran tatap muka (face to face)

Pembelajaran tatap muka adalah pembelajaran konvensional yang dilakukan dengan cara penyampaian informasi di dalam satu ruangan kelas. Pembelajaran ini mengharuskan pendidik dan pebelajar berada dalam satu waktu dan satu tempat tertentu. 
c. Collaboration (kolaborasi dari online learning dan face to face learning)

Collaboration merupakan perpaduan pembelajaran online dan tatap muka. Pembelajaran ini lebih fleksibel. Pebelajar bebas menggunakan pendekatan online apapun untuk mengakses materi pelajaran.

\section{Kelebihan dan Kelemahan Blended Learning}

Terdapat berbagai kelebihan pembelajaran Blended Learning diantaranya adalah:

a. Pembelajaran berbasis blended learning tidak terikat ruang dan waktu. Artinya, proses pelaksanaan pembelajaran berbasis blended learning dapat dilaksanakan kapan dan dimana saja (Saman et al., 2019).

b. Mahasiswa dapat lebih banyak belajar untuk menguasai materi karena konten pembelajaran pada laman online tersedia terus menerus (Saman et al., 2019).

c. Pembelajaran dapat dilakukan dari berbagai arah.

d. Bantuan media yang digunakan dapat lebih menyenangkan pebelajar (Istiqomah \& Anggun, 2019).

Pembelajaran berbasis blended learning juga memiliki kelemahan diantaranya:

a. Pebelajar cenderung mengungkapkan pendapat bukan dari hasil pemikirannya sendiri, melainkan hasil pencarian di internet.

b. Proses pembelajaran sangat bergantung pada jaringan internet. Hal ini akan terasa sulit untuk pebelajar yang jaringan internetnya tidak memadai. 
c. Internet, komputer, laptop, sarana dan prasarana lainnya menjadi kebutuhan mendasar yang harus dipenuhi dan memerlukan dana yang cukup besar.

Pembelajaran berbasis blended learning adalah proses pembelajaran yang memadukan pembelajaran offline dalam bentuk tatap muka dan pembelajaran online agar pebelajar tetap mampu menerima materi yang disampaikan dan mampu mencapai tujuan pembelajaran yang diharapkan. Pembelajaran berbasis blended learning menjadi salah satu solusi inovatif dalam proses pembelajaran jarak jauh untuk menghasilkan atmosfer pendidikan yang lebih bervariatif serta menyenangkan.

\section{DAFTAR PUSTAKA}

Abdullah, W. (2018). Model Blended Learning dalam Meningkatkan Efektifitas Pembelajaran. Jurnal Pendidikan Dan Manajemen Islam, 7(1), 855-866.

Aini, K. (2021). Analisis Proses Pembelajaran Daring pada Masa Pandemi. Jurnal Studi Guru Dan Pembelajaran, 4(1), 218-228.

Aini, K., Hobri, Prihandoko, A. C., Yuniar, D., Faozi, A. K. A., \& Asmoni. (2020). The students' mathematical communication skill on caring community-based learning cycle 5E. Journal of Physics: Conference Series, 1538(1). https://doi.org/10.1088/17426596/1538/1/012075

Anggraeni, C. S., Hidayati, N., Farisia, H., \& Khoirulliati, K. (2020). Trend Pola Asuh Orang Tua dalam Pendampingan Model Pembelajaran Blended Learning pada Masa Pandemi Covid-19. JECED: Journal of Early Childhood Education and 
Development,

97-108.

https://doi.org/10.15642/jeced.v2i2.915

Aslamiyah, T. Al, Setyosari, P., \& Praherdhiono, H. (2019). Blended Learning Dan Kemandirian Belajar Mahasiswa Teknologi Pendidikan. Jurnal Kajian Teknologi Pendidikan, 2(2), 109-114. https://doi.org/10.17977/um038v2i22019p109

Diana, P. Z., Wirawati, D., Rosalia, S., \& Dahlan, U. A. (2020). Blended Learning dalam Pembentukan Kemandirian Belajar. Alinea: Jurnal Bahasa Sastra Dan Pengajaran, 9(1), 16-22.

Dwiyogo, W. D. (2018). Pembelajaran Berbasis Blended Learning. PT Raja Grafindo Persada.

Eriani, E., \& Reni, A. (2020). Blended Learning: Kombinasi Belajar Untuk Anak Usia Dini di Tengah Pandemi. Mitra Ash-Shibyan Jurnal Pendidikan Dan Konseling, 03(01), 11-21.

Goldschmidt, K. (2020). The COVID-19 Pandemic: Technology use to Support the Wellbeing of Children. Journal of Pediatric Nursing, 53, 88-90. https://doi.org/10.1016/j.pedn.2020.04.013

Herliandry, L. D., Nurhasanah, N., Suban, M. E., \& Kuswanto, H. (2020). Pembelajaran Pada Masa Pandemi Covid-19. JTP - Jurnal Teknologi Pendidikan, 22(1), 65-70. https://doi.org/10.21009/jtp.v22i1.15286

Istiqomah, N., \& Anggun, B. K. (2019). Pembelajaran Blended Learning Matematika di Era Generasi Alpha. Prosiding Sendika, 5(1), 595-600.

Kurniawati, M., Santanapurba, H., \& Kusumawati, E. (2019). Penerapan Blended Learning Menggunakan Model Flipped Classroom Berbantuan Google Classroom Dalam 
Pembelajaran Matematika SMP. EDU-MAT: Jurnal Pendidikan Matematika, 7(1), 8-19. https://doi.org/10.20527/edumat.v7i1.6827

Makur, A. P., Jehadus, E., Fedi, S., Jelatu, S., Murni, V., \& Raga, P. (2021). Kemandirian Belajar Mahasiswa dalam Pembelajaran Jarak Jauh Selama Masa Pandemi. Mosharafa: Jurnal Pendidikan Matematika, 10(1), 1-12.

Saman, M. I., Koeshandayanto, S., \& Razak, A. (2019). Eksplorasi Literasi Teknologi Informasi dan Komunikasi Siswa melalui Blended Learning Fisika. Jurnal Pendidikan: Teori, Penelitian, Dan Pengembangan, 4(1), 79-84.

Sun, L., Tang, Y., \& Zuo, W. (2020). Coronavirus pushes education online. Nature Materials, 19(6), 687. https://doi.org/10.1038/s41563-020-0678-8 


\title{
PEMANFAATAN PENGGUNAAN MEDIA SOSIAL TIKTOK DALAM PEMBELAJARAN PPKN DI MASA PANDEMI COVID-19
}

\author{
Sri Okta Puspita,S.Pd ${ }^{28}$ \\ (SMP Negeri 1 Tanah)
}

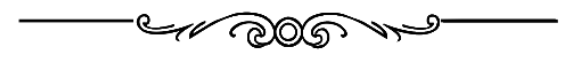

"Penerapan media pembelajaran PPKn dengan menggunakan media Sosial TikTok di masa Covid-19 ini, membuat siswa tidak bosan dalam belajar daring"

\begin{abstract}
Dandemi yang mulai masuk pada desember 2019 di Dunia, membuat Indonesia termasuk salah-satunya, dimulai pada maret 2020 Covid-19 mulai memasuki Indonesia, dan pada saat itu juga di berlakukanya Sekolah dirumah, dengan menerapkan pembelajaran jarak jauh (PJJ), baik dari tingkat sekolah maupun perguruan tinggi, maka dari itu menerapkan media pembelajaran berbasisi daring (online), hal ini membawa dampak positif juga bagi indonesia, Karena mulai mengikuti perkembangan zaman.
\end{abstract}

${ }^{28}$ Penulis lahir di Tanah Abang Utara, 27 Oktober 1998, penulis merupakan Guru di SMP N 1 Tanah Abang Kab. Penukal Abab Lematang Ilir, Penulis menyelesaikan Gelar S1 Jurusan IPS Program Studi PPKn di Universitas Sriwijaya (2020). 
Kemudian adanya peraturan dikeluarkan oleh permendikbud No 24 Tahun 2012 tentang pembelajaran jarak jauh dalam Pasal 1 Ayat 1 berbunyi:

"Pendidikan jarak jauh yang selanjutnya disebut PJJ adalah pendidikan yang peserta didiknya terpisah dari pendidik dan pembelajarannya menggunakan berbagai sumber belajar melalui teknologi informasi dan komunikasi dan media lain."

Dalam hal ini, pembelajaran berbasis PJJ diterapkan di masa pandemik covid-19, dengan menerapkan berbagai macam media dan model pembelajaran berbasis online, seperti menggunakan media pembelajaran media sosial Tiktok,

Tik Tok ialah aplikasi jaringan sosial media dan platform video music asal Tiongkok yang mulai di luncurkan pada September tahun 2016. Aplikasi ini di pergunakan oleh para penggunanya untuk membuat video berdurasi pendek,

Berdasarkan data penelitian Fatimah Kartini Bohang (2018), menunjukkan sepanjang kuartal pertama (Q1) 2018, Tik Tok menjadi aplikasi paling banyak diunduh yakni 45,8 juta kali. Jumlah tersebut mengalahkan berbagai aplikasi laiinnya seperti YouTube, WhatsApp, Facebook, dan Instagram. Sekitar 10 juta pengguna aktif media sosial Tik Tok di Indonesia, mayoritas adalah anak milenial, usia sekolah, atau biasa dikenal dengan generasi Z (menurut tekno.kompas.com).

Maka dari hal itu, pengguna Tik Tok di Indonesia ialah para generasi Milenial, dan di senangi dari anakanak, remaja hingga dewasa. Hal ini dapat kita lihat bahwa media sosial Tik Tok Menjadikan siswa yang interaktif, bagi peserta didik, dan memenuhi kriteria bahwa sebuah media Tik Tok ini menrik dan dekat dengan peserta didik dan memenuhi kriteria 
pembelajaran yang baik yang dapat dikelolah untuk menjadi media pembelajaran PPKn di masa pandemik Covid-19,

Menerapkan media sosial Tiktok dalam media pembelajaran ini, ialah membuat siswa lebih aktif dan seru dalam menggunakan media ini, karena media ini sudah tidak asing lagi bagi peserta didik ini, meskipun terkadang jaringan susah untuk di dapat, tapi saat ini jaringan sudah mulai lancar di Kabupaten Penukal Abab Lematang Ilir, guru pun memberikan waktu dalam penerapan media sosial ini, untuk menerapkannya sangat mudah setelah mendownload di Play Store di (Android), maka peserta didik membuat akun dengan mengisi No telpon/email dan membuat nama mereka dalam menggunakan Tik Tok, seperti membuat Tiktok yang ditugaskan pada saat Hari Pancasila semua siswa SMP Negeri 1 Tanah Abang Kabupaten Penukal Abab Lematang Ilir, membuat TikTok dengan tema hari pancasila, hari guru, Hari Kartini, kemudian link di share di grub whatshapp, dan guru membuka dan menilai karya siswa yang telah dibuat.

Penilaian yang diberlakukan pada masa Pandemik ini, bukan hanya aktif siswa dan guru, tetapi kreativitas dan kesungguhan para peserta didik ini yang dijadikan suatu penilaian, karena membuat video ini haruslah menarik disertai dengan keinginan dan kesungguhan para Peserta Didik, apalagi jika video tersebut FYP (For your page) Artinya video tersebut berkualitas bagus dan menarik yang pastinya sesuai dengan Nilai dan Norma yang berlaku, sehingga banyak yang menontonnya hal ini membuat siswa semakin semangat dalam hal belajar PPKn secara Pembelajaran Jarak Jauh,

Selain itu juga guru pun membuat video pembelajaran di Tiktok seperti mengenalkan Nilai-Nilai Pancasila, Macam-Macam Nilai Dan Norma, Hak Asasi 
Manusia, Semangat Kebangsaan, Makna Bhineka Tunggal Ika, dan sesuai dengan RPP dan Silabus yang telah dibuat, melakukan latihan dan jawaban dari video yang telah dibuat oleh guru tersebut, kemudian di berikan komentar, dan share agar semua orang bisa menggunakan konten edukasi ini, dan agar peserta didik bisa menjawab soal yang telah diberikan, setelah diberikan waktu yang telah di tentukan oleh guru, seperti 3 hari, ataupun 1 minggu, mengingat Jaringan setiap desa yang ada di Kecamatan Tanah Abang ini, tidak setiap desa memiliki jaringan Cepat, maka dari itu guru memberikan waktu agar peserta didik dapat mengikuti media pembelajaran ini.

Dengan demikian, menerapkan media pembelajaran PPKn dengan menggunakan media Sosial TikTok di masa Covid-19 ini, membuat siswa tidak bosan dalam belajar daring, menjadi kreatif dan menggunakan dalam hal postif serta memanfaatkan hal-hal yang baru, yang berlaku di industry 4.0 pada saat ini,

Tak lepas dari itu, pembelajaran media ini pun harus didampingi oleh orang Tua/Wali, karena orang tua harus ikut mengawasi dalam proses pembelajran PJJ/ Daring ini, seperti yang kita ketahui selain positif, TikTok ini pun membawa dampak negative bagi peserta didik, jika tidak di awasi maka peserta didik ini akan membuka dan membuat konten Tiktok yang tidak sesuai dengan Nilai dan Norma yang berlaku di Indonesia, karena peserta didik tadi merasa senang oleh Fyp, maka harus di batasi dengan pengawasan orang tua.

Dengan demikian aktivitas kegiatan belajarmengajar di masa Pandemi dapat berjalan dengan Lancar sebagaimana mestinya, dan kita harus tetap menjaga kesehatan, agar terhndar dari berbgai macam virus, buka hanya covid-19 tapi virus-virus yang baru 
yang menyebar di dunia, semoga covid-19 cepat berkahir dan kita semua bisa menjalankan pembelajaran seperti biasa.

\section{DAFTAR PUSTAKA}

Dewanta, 2020. Jurnal Pendidikan dan Pembelajaran Bahasa Indonesia: Pemanfaatan Aplikasi Tiktok sebagai Media Pembelajaran Bahasa Indonesia. No 2, vol 92020 https://ejournalpasca.undiksha.ac.id

Nugoroh, Aji., Putu Setyadi,Dwi Bambang. 2020. Jurnal Pendidikan UMP: Aplikasi Tik Tok Sebagai Media Pembelajaran Keterampilan Bersastra. Metafora No 2, vol 72020 http://jurnalnasional.ump.ac.id 
222 | Yang Terdepan dalam Menghadapi Pembelajaran Daring 


\title{
EFEKTIVITAS WHATSAPP DAN GOOGLE CLASSROOM DALAM PEMBELAJARAN DARING MATA PELAJARAN BAHASA INDONESIA
}

\author{
Siti Zukana, S.Pd. ${ }^{29}$ \\ (MTs. N 1 Kudus)

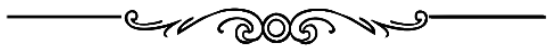

"WhatsApp dan Google Classroom merupakan dua aplikasi yang sangat efektif dalam pembelajaran daring. WhatsApp sangat bermanfaat untuk kontrol keikutsertaan peserta didik dalam pembelajaran daring dan google classroom dapat digunakan secara variatif dan multifungsi"

\begin{abstract}
Denerapan pembelajaran daring sejak bulan Maret P 2020, tepatnya tanggal 16 Maret 2020 telah mengubah perwajahan pendidikan khususnya di Indonesia. Pembelajaran daring merupakan opsi terbaik yang diterapkan oleh pemerintah demi mengurangi risiko penyebaran virus corona. Pemerintah telah membuat regulasi/kebijakan khususnya pendidikan

${ }^{29}$ Penulis lahir di Klaten, 14 Januari 1975, penulis merupakan Guru MTs. N 1 Kudus dalam bidang ilmu Bahasa Indonesia, penulis menyelesaikan gelar Sarjana Pendidikan Bahasa dan Sartra Indonesia di IKIP Negeri Semarang yang sekarang bernama UNNES.
\end{abstract}


untuk semua lini yaitu dengan menerapkan pembelajaran jarak jauh dari rumah secara daring (dalam jaringan).

Pembelajaran jarak jauh merupakan pembelajaran yang diikuti oleh peserta didik dari rumah/ tempatnya berada dengan menggunakan teknologi komunikasi, informasi, dan media lainnya. Handphone android/ smartphone yang terjalin jaringan internet merupakan perangkat yang sering digunakan dan biasa dimanfaatkan oleh peserta didik dalam mengikuti pembelajaran jarak jauh. Perangkat ini memberikan banyak fasilitas melalui aplikasi-aplikasinya.

Pelaksanaan pembelajaran bahasa Indonesia dalam praktiknya menggunakan perpaduan/ kolaborasi berbagai aplikasi. Dalam hal ini, aplikasi yang digunakan adalah WhatsApp dan google classroom. Aplikasi ini dipilih karena banyak kemudahan yang dirasakan baik oleh peserta didik maupun pendidik.

\section{A. WhatsApp}

WhatsApp merupakan aplikasi yang sudah biasa digunakan oleh masyarakat, sehingga ketika pembelajaran daring menggunakan aplikasi ini tidak ada kendala yang berarti bagi peserta didik dan pendidik. Pada awal pembelajaran daring, pendidik membuat grup kelas yang diampu denganmenggunakan aplikasi WhatsApp. Melalui grup kelas tersebut, komunikasi antara pendidik dan peserta didik dapat terjalin. Pendidik memulai pembelajaran dengan salam, mengajak berdoa, memotivasi, dan pertanyaanpertanyaan ringan yang menarik. Selanjutnya, pendidik dapat menyampaikan materi pembelajaran. Materi yang disampaikan bisa berupa video, gambar, materi yang dikemas dengan dokumen. Melalui WhatsApp, pendidik dapat memantau peserta didik melalui info. Pendidik 
dapat mengetahui siapa saja yang sudah membaca pesan yang telah dikirimkan. Nah, jika masih ada beberapa siswa yang belum online dan membaca pesan yang telah dikirim, maka pendidik bisa menghubungi langsung nama-nama siswa yang belum bergabung. Jika peserta didik belum bisa dihubungi, langkah selanjutnya adalah menghubungi orang tua dengan harapan peserta didik segera bergabung dalam pembelajaran online.

Ada cara lain yang bisa dilakukan oleh pendidik untuk menjadikan peserta didik tetap aktif mengikuti pembelajaran online, yaitu dengan memberikan perintah untuk lapor diri di grup WhasApp. Peserta didik diminta untuk menuliskan (nama-no.absen-Siap mengikuti PJJ). Perintah ini memberikan efek yaitu mengikat peserta didik untuk tetap mengikuti PJJ sampai akhir, apalagi kalau ada tagihan yang harus dikumpulkan pada jam pembelajaran. Pemantauan terhadap peserta didik tidak cukup sampai di situ. Di sela-sela pembelajaran, pendidik bisa menuliskan nama-nama peserta didik yang belum bergabung. Dengan demikian ada efek jera sehingga pada pertemuan berikutnya, peserta didik akan lebih tertib dalam mengikuti pembelajaran online.

Terkait penggunaan WhatsApp dalam pembelajaran online, menurut Wahsun dalam LPMP Jatim, WhatsApp paling diminati dalam pembelajaran online. Berikut data dalam Trend Penggunaan Platform Sistem Belajar Online oleh Guru di Tengah Wabah Pandemi. 


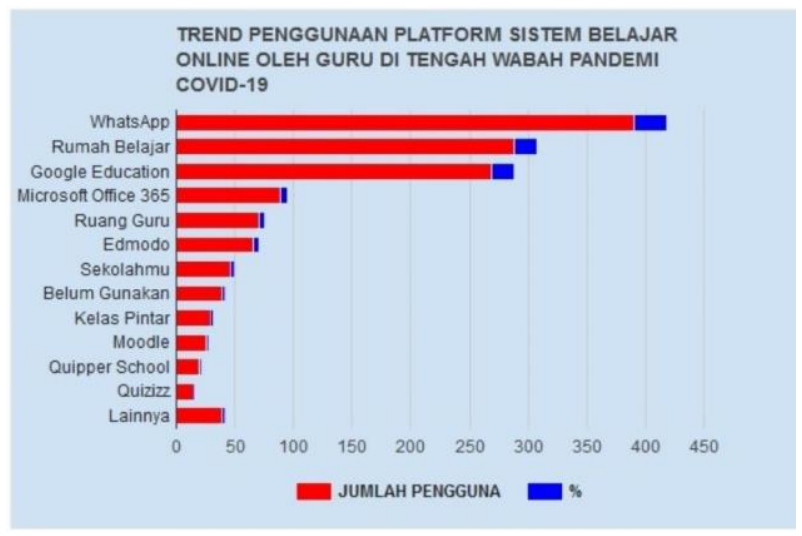

Sumber: LPMP Jatim (2020)

\section{B. Google Classroom}

Menurut glints, Google Classroom adalah platform gratis berbasis web yang dibuat untuk mempermudah kegiatan pembelajaran pendidik dan murid. Sedangkan menurut Wikipedia, Google Kelas (bahasa Inggris: Google Classroom) adalah layanan web gratis, yang dikembangkan oleh Google untuk sekolah, yang bertujuan untuk menyederhanakan membuat, mendistribusikan, dan menilai tugas tanpa harus bertatap muka. Tujuan utama Google Classroom adalah untuk merampingkan proses berbagi file antara guru dan siswa.

Melalui aplikasi google classroom, pendidik dapat memberikan tugas kepada peserta didik dan dapat melakukan penilaian tanpa menggunakan kertas. Google classroom juga dapat difungsikan untuk memberikan dan menambahkan materi baik dari youTube, video, maupun dokumen lain yang berada di google drive. Melalui google classroom juga, komunikasi 
dan kerjasama dan kerja sama dapat berjalan dengan lancar meskipun antara pendidik dan peserta didik berada di tempat ang berbeda. Selain itu, google classroom dapat menyimpan dengan rapi, aman dan terintegrasi dengan produk google lainnya.

Bagi peserta didik, google classroom dapat dimanfaatkan untuk melihat secara langsung tugastugas yang dishare oleh pendidik. Selain itu, peserta didik dapat mengumpulkan tugas-tugasnya dan mengecek penilaian yang dilakukan oleh pendidik. Melalui aplikasi ini juga, peserta didik dapat berdiskusi dengan pendidik, dan antar peserta didik.

WhatsApp dan Google Classroom merupakan dua aplikasi yang sangat efektif dalam pembelajaran daring. WhatsApp sangat bermanfaat untuk kontrol keikutsertaan peserta didik dalam pembelajaran daring dan google classroom dapat digunakan secara variatif dan multifungsi. Pada prinsipnya, pendidik dan peserta didik sangat dimudahkan dan diringankan dengan adanya WhatsApp dan google classroom.

\section{DAFTAR PUSTAKA}

https://glints.com/id/lowongan/google-classroomadalah/\#.YKRy6Kj7TIU (diakses pada hari Rabu tanggal 19 Mei 2021)

https://id.wikipedia.org/wiki/Google_Kelas (diakses pada hari Rabu tanggal 19 Mei 2021)

https://lpmpjatim.kemdikbud.go.id/site/detailpost/wh atsapp-paling-diminati-untuk-pembelajaranonline\#: :text=Hasil\%20survey\%20menunjukka n\%20bahwa\%20penggunaan,orang\%3A\%2028 \%2C14\%25).\&text=Dari\%20data\%20tersebut $\% 2$ 0dapat\%20disimpulkan,dengan $\% 20$ menggunaka 
n\%20'WhatsApp\%20Group'. (diakses pada hari Rabu tanggal 19 Mei 2021)

228 | Yang Terdepan dalam Menghadapi Pembelajaran Daring 


\title{
EFEKTIVITAS PENGGUNAAN BERBAGAI MACAM SUMBER BELAJAR UNTUK MENINGKATKAN KETERCAPAIAN BELAJAR DI ERA PANDEMI COVID-19
}

\author{
Ndaru Kukuh Masgumelar, S.Pd., M.Pd ${ }^{30}$ \\ (SMA Negeri 1 Bantur, Kab. Malang)

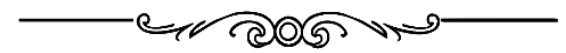

"Dengan adanya berbagai macam sumber belajar dapat menjadikan sebuah kemudahan dalam pembelajaran khususnya pada saat pandemi covid-19"

\begin{abstract}
Dandemi covid-19 yang telah terjadi di Indonesia banyak memberikan segala dampak di berbagai sektoral. Salah satu sektor yang merasakan dampaknya adalah bidang pendidikan. Dengan adanya pandemi covid-19 ini telah menggeser paradigma gaya belajar lama konvensional menjadi pembelajaran yang lebih visioner begitupun juga sumber belajar yang digunakan menjadi semakin beragam. Pengajar yang dulunya mengabaikan tentang perubahan pembelajaran dan

\footnotetext{
30 Penulis lahir di Malang, 04 April 1995, penulis merupakan tenaga pendidik SMA Negeri 1 Bantur dalam bidang pendidikan jasmani, penulis menyelesaikan gelar Sarjana Pendidikan di Universitas Negeri Malang Program Studi Pendidikan Jasmani dan Kesehatan (2017), sedangkan gelar Magister Pendidikan diselesaikan di Universitas Negeri Malang Program Studi Pendidikan Olahraga (2019).
} 
sumber belajar secara tidak langsung harus merubah cara berfikir untuk menyesuaikan belajar pada situasi pandemi covid-19 tersebut.

Pembatasan interaksi pada lingkungan belajar dilakukan semenjak era pandemi covid-19 sesuai instruksi dari Pemerintah melalui Kementrian Pendidikan, Kebudayaan, Riset dan Teknologi. Bermacam-macam cara belajar secara online atau virtual mulai diperkenalkan. Dari awalnya banyak yang alergi dengan teknologi mulai memanfaatkan sumber belajar berbasis teknologi dalam mensukseskan pembelajarannya. Karena tuntutan untuk meningkatkan kualitas pembelajaran dan ketercapaian belajar selalu ada apapun situasi dan kondisinya. Banyak developer aplikasi dari berbagai negara maju mendapatkan berkah dari pandemi tersebut karena aplikasi yang mereka kembangkan dapat digunakan dan dimanfaatkan secara masal setelah sebelumnya jarang ada yang meliriknya, misalkan saja zoom meeting, google classroom, google meet yang mulai populer pada saat pandemi covid-19.

Dari berbagai sumber belajar yang telah diterapkan dalam suatu proses pembelajaran tentunya terdapat beberapa sumber belajar yang dapat berdiri sendiri dan ada sumber belajar yang berkolaborasi sehingga tingkat keefektifannya juga tergantung pada apa yang disampaikan, siapa yang menerima penyampaian, dan bagaimana tingkat kesulitan apa yang disampaikan. Contohnya pada tingkat pendidikan dasar tidak mungkin selalu memanfaatkan sumber belajar yang basis nya hanya condong pada evaluasi materi saja, akan tetapi lebih cocok jika mereka diberikan sebuah sumber belajar yang banyak memuat materi secara visual, contoh dalam implementasi kehidupan seharihari, dan sumber belajar yang lebih mengarah ke interaktif. Berbeda dengan tingkat sekolah atas maupun 
perguruan tinggi, mereka sudah dapat menalar sesuatu yang lebih kompleks jadi diberikan sumber belajar dan gaya belajar apapun masih cocok untuk mereka gunakan.

Pendidik sebagai manajemen sumber belajar juga mempunyai peran penting dalam mengatur persentase dari penggunaan berbagai sumber belajar yang digunakan dalam pembelajaran. Jangan sampai pengajar mempunyai persentase yang sangat dominan bahkan $100 \%$ untuk menjadi sumber belajar bagi peserta didik. Karena dapat menimbulkan kejenuhan belajar pada peserta didik pada lingkungan belajar. Berikan persentase yang seimbang antara sumber belajaryang satu dengan lainnya agar peserta didik dapat memilih sumber belajar yang cocok dengan dirinya. Secara garis besar sumber belajar yang ada memuat 3 gaya belajar suatu peserta didik yaitu auditori, visual, dan kinetik, dimana masing-masing peserta didik mempunyai gaya belajar yang berbeda. Oleh karena itu sebagai pendidik mempunyai peran penting dalam manajemen sumber belajar agar semua peserta didik dapat terfasilitasi sesuai dengan gaya belajarnya, terutama pada era pandemi covid-19.

Macam-macam sumber belajar secara garis besar dapat dikelompokkan menjadi 3 macam yaitu tatap muka, offline, dan online yang lebih dikenal dengan pembelajaran campuran/blended/hybrid. Penerapan blended learning pada bidang studi pendidikan olahraga di SMA akan menambah model pembelajaran yang selama ini hanya menggunakan tatap muka dalam belajar (Masgumelar \& Mustafa, 2021). Potensi yang dapat dimanfaatkan dalam lingkungan belajar dengan pembelajaran ini tergolong sangat menjanjikan (Masgumelar \& Dwiyogo, 2020). 
Misalkan pada tatap muka pengajar menjadi sumber belajar yang dominan dalam menyampaikan apa yang perlu disampaikan pada peserta didik, pada offline sumber belajar tanpa jaringan internet menjadi dominan misalkan audio, audiovisual sehingga pendidik berperan sebagai fasilitator dalam sumber belajar tersebut, sedangkan pada pembelajaran online sangat bergantung pada adanya jaringan internet sehingga kesuksesan belajar online ditentukan oleh ketersediaan sarana prasarana penunjang yang ada. Apabila ketiganya digabungkan menjadi sebuah sistem pembelajaran maka akan menciptakan suasana belajar kapan saja dan dimana saja.

Keefektifan suatu sumber belajar dapat diukur dari suatu ketercapaian hasil belajar. Ketercapaian hasil belajar adalah diukur dari aspek efektivitas, efisiensi, dan daya tarik dari suatu sumber belajar tersebut. Efektivitas pmbelajaran adalah tingkat ketercapaian pebelajar/siswa pada tujuan atau isi bidang studi yang telah ditetapkan. Efisiensi pembelajaran adalah tingkat efisiensi suatu pembelajaran, indikator utamanya berfokus pada waktu, personalia, serta sumber belajar yang telah digunakan. Penggunaan/penerapan waktu untuk mencapai tujuan yang sudah dirumuskan, penggunaan/penerapan jumlah personalia/pihak yang terlibat dalam proses pembelajaran, penggunaan/penerapan sumber belajar yang sudah susun sedemikian rupa untuk pembelajaran. Hasil dari analisis ketiga hal tersebut kemudian dijadikan acuan untuk mengukur tingkat efisiensi program pembelajaran. Daya tarik pembelajaran erat sekali kaitannya dengan daya tarik bidang studi. Daya tarik bidang studi dalam penyampaiannya akan banyak tergantung pada kualitas pembelajaran untuk pengukuran daya tarik pembelajaran dapat dilakukan dengan mengamati apakah siswa ingin terus belajar 
atau tidak. Kecenderungan siswa untuk tetap terus belajar bisa terjadi karena daya tarik bidang studi itu sendiri, atau bisa juga karena kualitas pembelajarannya, atau bisa jadi keduanya.

Berikut ini adalah kajian-kajian dari efektivitas penggunaan berbagai macam sumber belajar yang telah diimplementasikan pada pembelajaran. Hasil dari penelitian Masgumelar, Dwiyogo \& Nurrochmah (2019) dengan menggunakan pembelajaran berbasis blended learning pada pembelajaran pendidikan jasmani SMA dengan tatap muka menggunakan buku ajar, offline menggunakan multimedia, dan online menggunakan edmodo maka diperoleh efektivitas sumber belajar pada setiap pertemuan diperoleh peningkatan nilai, yaitu: (1) antara pertemuan pertama dan pertemuan kedua peningkatan nilai diperoleh rata-rata peningkatan 0,38 dengan persentase peningkatan $0,48 \%$, (2) antara pertemuan kedua dan ketiga diperoleh peningkatan nilai diperoleh rata-rata peningkatan 1,25 dengan persentase peningkatan $1,56 \%$.

Hasil penelitian dari Setiawan (2019) pada pembelajaran karate di PPG Universitas Negeri Malang dengan menggunakan sumber belajar buku karate, multimedia interaktif, dan online edmodo diperoleh efektivitas sumber belajar setiap pertemuan diperoleh peningkatan nilai, yaitu: (1) pada pertemuan pertama ke pertemuan kedua mengalami peningkatan 1,92\%, (2) pada pertemuan kedua ke pertemuan ketiga mengalami peningkatan 2,15\%. Rata keseluruan dari semua pertemuan dengan hasil nilai 90,29 kredit A. Menurut panduan Universitas Negeri Malang sekurangkurangnya nilai 59 atau $\mathrm{C}$ masih dikategorikan tuntas atau diakui kreditnya sehingga dari data yang diperoleh mahasiswa dikatakan tuntas. 
Hasil penelitian dari Ardilla, et all (2021) dengan menggunakan sumber belajar articulatio storylane Didapatkan hasil data yaitu dengan persentase ahli pembelajaran 90\%, Ahli permainan SD 96\%, Ahli PJOK $77 \%$, Ahli Media 96\%, Ahli Kebugaran Jasmani 78\%, kemudian $91 \%$ untuk uji coba I dan $89 \%$ untuk uji coba II. Kesimpulan dalam penelitian pengembangan ini yaitu produk pengembangan aplikasi articulate storyline ini layak untuk dipergunakan sebagai penunjang dalam pembelajaran kebugaran jasmani.

Kesimpulan dengan adanya berbagai macam sumber belajar dapat menjadikan sebuah kemudahan dalam pembelajaran khususnya pada saat pandemi covid-19. Tingkat keefektifan sebuah sumber belajar dapat diukur jika memenuhi aspek efektivitas, efisiensi, dan daya tarik dari suatu sumber belajar tersebut. Sehingga sumber belajar yang satu dengan yang lainnya tidak dapat dijadikan patokan sebagai sumber belajar yang unggul, karena sumber belajar yang tepat dan efektif adalah sumber belajar yang dapat meningkatkan ketercapain suatu belajar dari peserta didik.

\section{DAFTAR PUSTAKA}

Ardilla, M. W., Wiguno, L. T. H., Kurniawan, A. W., \& Mu'arifin. 2021. Pengembangan Perangkat Pembelajaran Kebugaran Jasmani Berbasis Aplikasi Articulate Storyline. Sport Science and Health. 3(4), 192-205.

Masgumelar, N. K., \& Dwiyogo, W. D. 2020. Development of Game Modification Using Blended Learning in Physical Education, Sports, and Health For Senior High School Students. The 3rd International Conference on Sports Sciences and Health 2019 (ICSSH 2019), 95-100. Atlantis Press. 
Masgumelar, N. K., Dwiyogo, W. D., \& Nurrochmah, S. 2019. Modifikasi Permainan menggunakan Blended Learning Mata Pelajaran Pendidikan Jasmani, Olahraga, dan Kesehatan. Jurnal Pendidikan: Teori, Penelitian, dan Pengembangan, 4(7), 979-986.

Masgumelar, N. K., \& Mustafa, P. S. 2021. Pembelajaran Pendidikan Olahraga Berbasis Blended Learning Untuk Sekolah Menengah Atas. Jurnal Kesehatan Jasmani dan Olahraga, 6(1), 133-144.

Setiawan, W. B. 2019. Pengembangan Pembelajaran Karate Berbasis Blended Learning Mahasiswa Pendidikan Profesi Guru Pendidikan Jasmani dan Kesehatan. DISERTASI dan TESIS Program Pascasarjana UM. 